$$
\begin{aligned}
& \therefore=-1900 \\
& \text { Wू } i \text { i } 1096 \\
& \text { OSTI }
\end{aligned}
$$

\title{
Hanford Isotope Project Strategic Business Analysis Cesium-137 (Cs-137)
}

Prepared for the U.S. Department of Energy

Assistant Secretary for Environmental Management

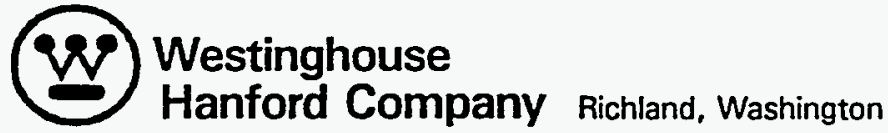

Management and Operations Contractor for the

U.S. Department of Energy under Contract DE-AC06-87RL10930 


\section{Hanford Isotope Project} Strategic Business Analysis Cesium-137 (Cs-137)

Economic Transition Center

Tri-City Industrial Development Council

Date Published

October 1995

Prepared for the U.S. Department of Energy Assistant Secretary for Environmental Management

(20)

Westinghouse

P.O Box 1970

Hanford Company Richland, Washington

Management and Operations Contractor for the

U.S. Department of Energy under Contract DE-AC06-87RL10930

Approved for public release 



\section{INTRODUCTION}

The purpose of this business analysis is to present the facts and assumptions based on the present knowledge base on the potential reuse of Cesium-137 (Cs137). Knowledge of these facts and assumptions are required so that timely decisions can be made by the government and perspective commercial business entities on whether or not to utilize a valuable national asset along with the potential to save millions of tax dollars. Cs-137 is useful for a number of commercial applications and even some foreign countries (i.e. China) have made inquiries about purchasing 1 arge quantities. Although there are business opportunities in these areas, the major use for the Cs-137 inventory is as a gamma ray source in food irradiators, which is the focus of this report. This basic fact requires that the business analysis for Cs-137 be intrinsically linked with the business $\mathrm{planning}$ and market analys is for the world-wide food irradiation market utilizing Cs-137 as the source. The primary Cs-137 supplied food irradiator design considered in this report is the dry storage conceptual design called "GRAY*STAR". Other possible Cs-137 source designs were not included due to unavailability of information at this time. This is a rather complex study and both the risk items (cost and liabilities) and key drivers (benefits for the Government, industry and public) contain emotional issues which can tend to mask the actual "business" facts.

This Plan consists of: the executive summary, the main body of supporting information and key informational appendices. The executive summary contains the Cs-137 primary market use (food irradiation), a discussion of key risks and Tiabilities, estimates of potential cost avoidance and other benefits for the Department of Energy, and a summary of near term actions required if the Government decides to move ahead with the opportunity. The main body presents a discussion of: (1) risk items (cost/liabilities), (2) key drivers (benefits/cost savings) and (3) timeline of decisions and actions required "IF" the decision is made to proceed with or further investigate this opportunity. The appendices contain the referenced supporting information. 

TABLE OF CONTENTS

1.0 EXECUTIVE SUMMARY

2.0 BACKGROUND AND CAPABILITY

2.1 Cesium-137

2.2 Competition/Market Projections

2.3 Manufacturing \& Business Constraints

3.0 RISK ITEMS (COST)

3.1 Public Acceptance

3.2 Liability/Litigation

3.3 Long Term Disposal

3.4 Cs-137 Inventory - Near Term

3.5 Cost Avoidance Financing (CAF)

3.6 Cs-137 Inventory - Long Term

3.7 Food and Drug Administration (FDA) Approval

3.8 Certification/Licensing

4.0 KEY DRIVERS (BENEFITS)

4.1 Cost Avoidance

4.1.1 Hanford WESF/B PTant Options

4.1.2 Savannah River Site Options

4.2 Food Borne Disease

4.3 Fresh Produce Life Extension

4.4 U.S. Agricultural Export Market

4.5 Import Treatment Costs

4.6 High Level Waste Storage

4.7 New Business

5.0 CONCLUSIONS OF MARKET STUDY

6.0 DECISIONS AND ACTIONS

APPENDICES

A. Cs-137 Re-encapsulation Process and Cost

B. Savannah River Cs-137 - Costs and Schedules

C. American Medical Association Report on Irradiation of Food

D. Marketing Study For Cs-137 in Food Irradiation Applications

E. Video - The GRAY*STAR Solution 



\section{EXECUTIVE SUMMARY}

This business analysis investigates the beneficial reuse of Cesium-137 (Cs-137) in order to utilize a valuable national asset and possibly save millions of tax dollars. The current inventory of Cs-137 in the United States is owned and managed by the Department of Energy (DOE) and is primarily located at the Hanford and Savannah River sites. The Hanford site has $\sim 50$ million curies (MCi) of melt-poured Cs-137 chloride salt stored in capsules at the Waste Encapsulation and Storage Facility (WESF) and another $63 \mathrm{MCi}$ of cesium-barium in the Hanford underground storage tanks. Savannah River site has an estimated $200 \mathrm{MCi}$ of Cs-137 in its waste tanks. At both sites, tank waste would have to be processed to extract the Cs-137.

The beneficial reuse of Cs-137 was investigated in a comprehensive marketing study (Appendix D) which describes the world-wide food irradiation market, by far the largest potential user of Cs-137, with identified target markets of seasonal fruits, vegetables and seafood, and also lower throughput meat and poultry plants. This business analysis is therefore focused on the possible utilization of Hanford's Cs-137 in the dry storage mode for food irradiation. The Cs-137 irradiator is very cost competitive in these target markets. However, as described in the marketing study, there are several very serious issues associated with the viability of Cs-137 use in the commercial market.

The most serious issue facing Cs-137 use is the perception associated with Cs-137 safety. Many people in the industry believe it is too dangerous to use. The SteriGenics plant accident in Decatur, Georgia in 1988 sensitized the Government, industry, and public to the consequences of mishandling Cs-137. Furthermore, the predominate competition (Nordion International, Ltd, a Canadian firm) is the dominate worldwide supplier of food irradiators and at present only use Co-60 sources which have an excellent safety record. Perceptions about Cs-137 are further clouded by the fact that it is a by-product of the U.S. Government's nuclear weapons program. This places a certain negative stigma on Cs-137. All of this drives many in the industry to think Cs-137's reputation is poor and consequently, they want nothing to do with it.

The marketing study concludes that the potential share of the fruit and vegetable market over the next 10 years for Cs-137 irradiators is about 31 units and that it will be slow in coming (i.e., the Co-60 irradiator must develop the market first). However, this does not include the meat and poultry market segment where a Cs-137 design has a strong economic advantage over other competitive products for smaller throughput producers. The marketing study recognizes that a new food irradiator design has been developed called the "GRAY*STAR" and is described in the attached short video "The GRAY*STAR Solution"(Appendix E). This design addresses and solves problems associated with past Cs-137 food irradiator units because it utilizes Cs-137 sources in the dry storage mode and is simple to operate and inherently safe. However, there will be many hurdles to overcome and actions to be initiated by the Government if it is to become a viable option in the future food irradiation market.

Besides the above mentioned market issues, any plan for the recovery and reuse of Cs-137 must be economically and politically attractive to the Government. Various scenarios for utilization of the material in the capsules at WESF and recovery of the Cs-137 from the Defense Waste Processing Facility (DWPF) flow stream at Savannah River were analyzed in terms of potential cost avoidance. The expected out year cost stream assuming operations as usual, 
(i.e. no privatization or commercial use of the Cs-137 inventory) was compared to options converting the Cs-137 to a useful product. This preliminary analysis gave results that are very favorable to the DOE's effort to cut the cost of it's cleanup mission while converting a "wartime by-product" for beneficial reuse. For the Hanford WESF, two cases are considered (with and without conversion to dry storage) and then the comparison is made to the GRAY*STAR solution. At Savannah River, two technology options are considered for changing the DWPF standard process and recovering the Cs-137 from the flow stream for use by the commercial manufacturer. A first cut of these cost avoidance calculations are as follows:

Hanford WESF/B plant: $\sim \$ 300$ Million Direct (no dry storage) OR $\sim \$ 20$ Million to $\$ 100$ million Direct (dry storage)

Savannah River: $\sim \$ 500$ Million direct (early shutdown DWPF) PLUS $\sim \$ 150$ Million direct (reduced canister disposal at federal repository)

In addition to the direct benefits associated with cost avoidance, an attempt was made to identify and quantify both the indirect risk items and the key drivers associated with the Cs-137 supplied food irradiation business. As with any prospective business venture, the potential benefits must outweigh the potential risks involved in order for needed investments to be available. A listing of the primary indirect risk items and key drivers associated with the food irradiation business are:

RISK ITEMS: Public acceptance, Liability/Litigation, Long term disposal, Cs-137 inventory, Cost avoidance financing, Food and Drug Administration (FDA) approval, Certification/licensing

KEY DRIVERS: Cleanup cost avoidance, Food borne disease prevention, fresh produce life extension, U.S. agricultural export market, import treatment costs, U.S. competitiveness, Hanford and Savannah River economic diversification

The combination of the positive cost avoidance for the government along with the potential indirect benefit to the country might be cause to further investigate this opportunity and make the necessary decisions. A few of the actions that would have to be considered by DOE in order to allow this concept to mature as a realistic business opportunity are as follows:

* Determine the lifetime cost associated with the baseline plan(s) for storage, maintenance and disposal of Cs-137 at the Hanford and Savannah River sites.

* Investigate and develop technical and management operation options to reuse WESF and DWPF Cs-137 inventory for use in commercial application.

* Determine the lifetime cost associated with the Cs-137 reuse options.

- If the cost differential and other benefits justify reuse, establish Cost Avoidance Financing (CAF) to cover up-front investment requirements and incentive to commercial business.

* Identify and accommodate the manufacturing constraints and long term liability issues to insure that private company can accept inherent risks in pursuing this business.

The remainder of this business analysis provides the detailed information of all important business issues, the marketing study and the GRAY*STAR design. 


\section{BACKGROUND \& CAPABILITY}

The purpose of this business analysis is to address the beneficial reuse of Cesium 137 (Cs-137) in order to utilize a valuable national asset and possibly save millions of tax dollars. Food irradiation is the front runner application along with other uses. This business analysis supports the objectives of the Department of Energy National Isotope Strategy distributed in August 1994 which describes the DOE plans for the production and distribution of isotope products and services. As part of the Department's mission as stated in that document: "The Department of Energy will also continue to produce and distribute other radioisotopes and enriched stable isotopes for medical diagnostics and therapeutics, industrial, agricultural, and other useful applications on a businesslike basis. This is consistent with the goals and objectives of the National Performance Review. The Department will endeavor to look at opportunities for private sector to co-fund or invest in new ventures. Also, the Department will seek to divest from ventures that can more profitably or reliably be operated by the private sector."

\subsection{Cs-137}

The current inventory of Cs-137 in the United States is located at the Hanford and Savannah River DOE sites. The Hanford site has $\sim 50$ Million curies (MCi) of meltpoured Cs-137 chloride salt stored in capsules at the Waste Encapsulation and Storage Facility (WESF) and another $63 \mathrm{MCi}$ of $\mathrm{Cs}-\mathrm{Ba}$ in the underground storage tanks. The Savannah River site has an estimated $200 \mathrm{MCi}$ of Cs-137 in its waste tanks. At both sites, tank waste would have to be processed to extract the Cs-137. The Cs137 that was packaged in the Hanford WESF capsules in the late 1970's and early 1980 's was shipped to various irradiation facilities throughout the country. A leak in one of the capsules at one of the facilities resulted in the recall of all the WESF capsules and the resulting damage and financial exposure caused DOE to become very cautious in considering future uses of the Cs-137 inventory.

Today, Cs-137 is receiving renewed interest from potential customers for applications of food, blood and medical product/instrument irradiation. The recent health problems around the nation caused by food-borne contamination such as E.coli in beef products and salmonella and campylobacteriosis in poultry, have given new emphasis for food irradiation. Also, with the advent of the GATT treaty and the potential phaseout of methyl bromide, the export of fresh produce could be in jeopardy without the wide use capability of food irradiation.

A private firm has also produced a new food irradiator design that uses Cs-137 sources specifically designed for food irradiation. The firm is predicting a world-wide market of well over one billion curies in a food irradiator design that would be attractive to individual farmers and meat packers. The "intent" would be to reencapsulate Cs-137 and perform the final assembly of the units near Hanford, since the rugged units will also serve as shipping casks. This new food irradiator design called the "GRAY*STAR" is completely described in the short video "The GRAY*STAR Solution". The massive prefabricated steel units would be shipped directly to the customer's site by rail or 
special truck, where it can be installed and made operational in less than a day. Because Cs-137 is used as the radiation source and has a half-life of 30 years (six times that of (0-60), on-site source replenishment is not required. The operation of the unit is quite simple, and does not require highly trained, licensed personnel. Since the GRAY*STAR design is inherently safe, no one can ever be harmed by radiation from ordinary operator mistakes even if all of the equipment fails.

This presents some of the background of the Cs-137 reuse issue and the remainder of the business analysis will attempt to outline the factual business data, present a fair analysis of the risks and benefits and a time line of required actions if the government should decide to pursue or further investigate the opportunity.

\subsection{Competition/Market Projections}

The attached marketing study (appendix $D$ ) does a thorough job in analyzing the competitive technologies in the food irradiation business. The primary and dominant competitor is the Canadian firm, Nordion International, Ltd. whose business is to manufacture and supply cobalt-60 sources and design/install Co-60 irradiation systems. They are currently marketing $\mathrm{Co}-60$, however a recent meeting with Nordion indicated that they have a division dedicated to designing a Cs-137 irradiator. There are many pluses and minuses when comparing Co-60 and Cs-137, but in the true business sense it may come down to looking at different market segments and comparing economic costs of operations. Pages 31/31a of the marketing study give some simple trends and sample economic data for various irradiator types.

The Nordion (Freestanding/on line) unit has theoretical high volume throughput while the GRAY*STAR (batch) unit has limited throughput capability on a single unit basis. The free standing plant is for contract service providers or food processors and has very high throughput potential. An example of this type of plant is the Food Tech Services facility located in Mulberry, FI. that irradiates a large variety of food products for many different customers. The on-line continuous irradiator, while theoretical only (none in practice), would be dedicated to a processing plant for selected high volume foods such as ground beef only at a meat plant or chicken breasts only at a poultry plant. The On-line continuous and freestanding machines will be more economic than batch (GRAY*STAR) design at very high throughput while the batch machines will be much more economic to other machines at low throughput levels.

The volume of food product throughput (pounds per year, Ibs/yr) where the costs per pound for irradiation is equivalent between the batch units and the freestanding/on line unit is called the crossover point. The importance of the crossover point is that it allows identification of the approximate "market segments" where a particular irradiator type should be more economically competitive than others for various food groups. The crossover point analysis is very important then in predicting market share between competitive designs and options. 
The crossover point is materially influenced by many parameters including the price charged for the source (i.e., Cs-137 or Co-60) and the operations overhead required per irradiator type. To gain a better perspective on future market projections, a sample parametric study was done to show economic comparisons (cost per pound vs. throughput volume) for the poultry and papaya applications. These sample economic comparisons are for illustration only since many assumptions had to be made; however, the trends shown will hold true. Figure 1 gives the comparisons for the poultry application and shows a crossover point for two values of cost of Cs-137.

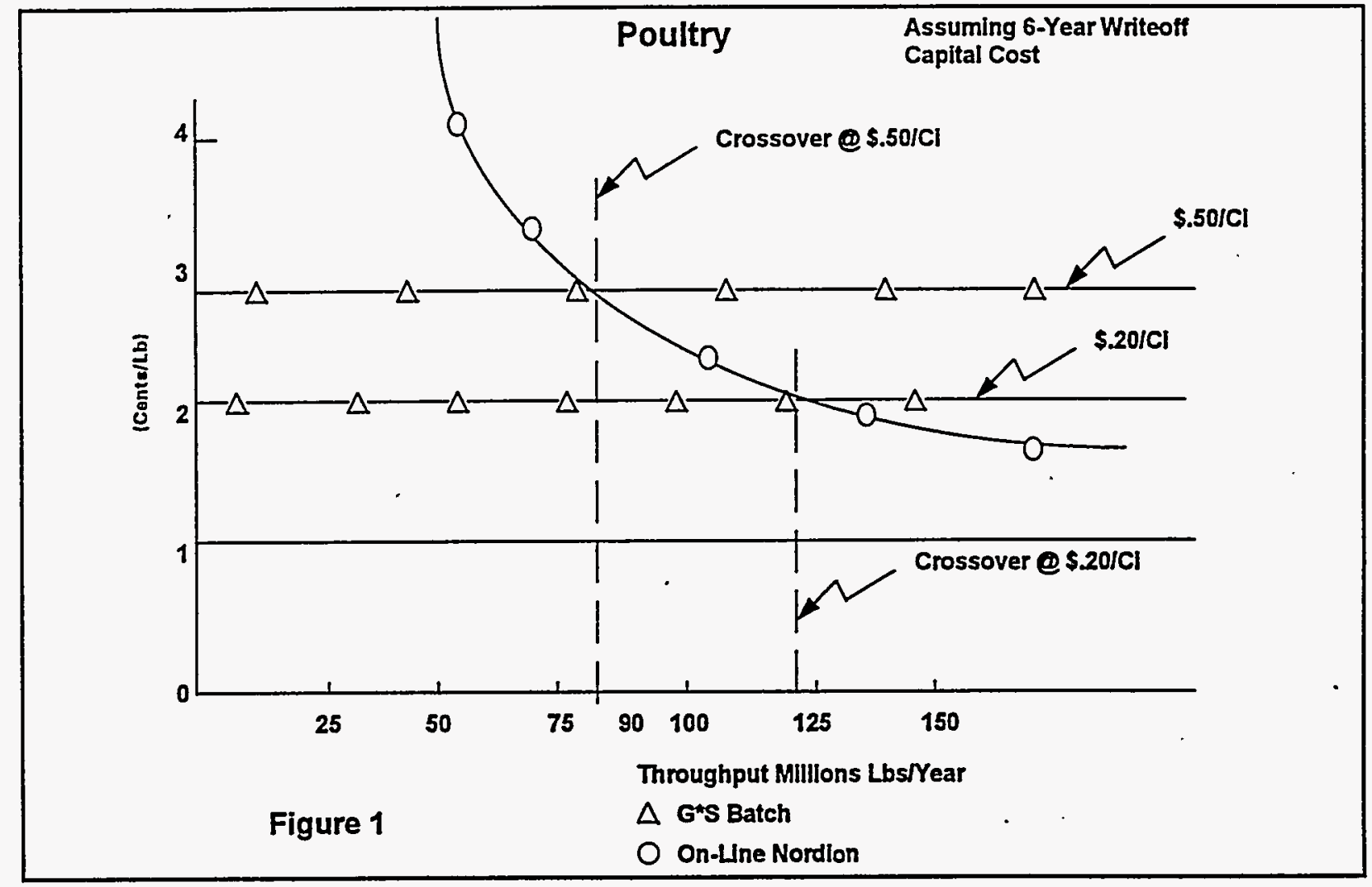

A discussion of the theoretical cost of encapsulated Cs-137 will be given later in the report. The main conclusion drawn from figure 1 is that the Batch (GRAY*STAR) machine is very cost competitive in the range of a large percentage of the poultry producers packing plants. In fact, assuming the cost of Cs-137 at the larger $\$ .50$ per $\mathrm{Ci}_{\text {, }}$ the crossover point indicates a competitive market segment for the GRAY*STAR batch units that contains over half of the poultry processing plants in the U.S. At question, of course, is how much economic advantage may be required to overcome the emotional issues tied to the Cs-137?

Likewise, figure 2 gives the comparisons for the papaya application and shows a strong economic advantage for the Batch unit over the larger Co-60 units for throughput equivalent to approximately $70 \%$ of the total annual Hawailan output. These 
two figures give evidence that in the true business sense, the Cs-137 batch machine would be quite cost competitive for many market segments.

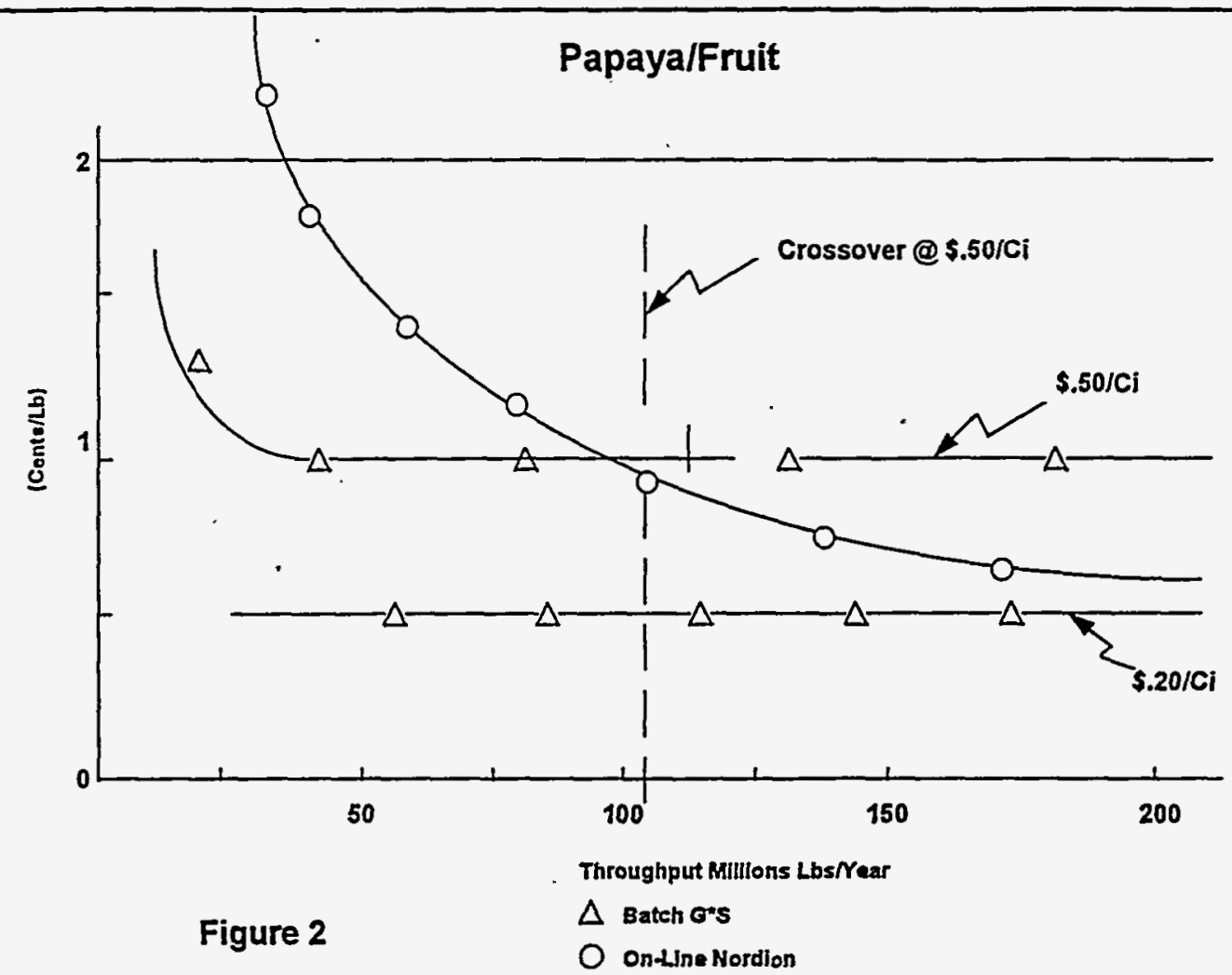

There are a multitude of factors that go into any market projection analysis. The market study discusses most of them including the cost economic trends presented above. The projected sales of food irradiators presents a special challenge because of the emotional issues plus U.S. Food and Drug Administration (FDA) policy and approval hurdles. The marketing study attempts to give projected sales of food irradiators for the fruit and vegetable applications only. Page 104-a of the marketing study predicts a 10year total market for all irradiators of 220 units with the Cs-137 (GRAY*STAR) share of 31 units. The low throughput meat and poultry sales would be additional to this and as seen from the crossover parametric analysis, this market segment includes over $50 \%$ of all meat and poultry producers. 


\subsection{Manufacturing \& Business Constraints}

Before discussing the risks and benefits associated with Cs-137 food irradiation systems, it will be helpful to describe a few of the identified issues associated with the potential manufacturer's willingness to participate in this business venture. There are obviously a large number of issues and assumptions that enter into any financial analysis of a potential new manufacturing business and some of the assumptions become absolute constraints with respect to limiting corporate liability and returning required investment with a reasonable profit to the shareholders. The attached market study provides a good understanding of the overall market potential, market drivers and, of course, the key market resistance associated with business entry. However, the issues associated with actual manufacturing of the product and transportation to the end customer must also be dealt with and resolved. A partial list of the items that should be resolved for the manufacturer are as follows:

\section{Number of units (minimum)}

A key constraint in the financial analysis is the minimum number of units that will be manufactured in order to allocate investment and overhead costs and to determine pricing requirements and judge if the market will accept. The available inventory of Cs137 is the limiting factor in determining the number of units that can be manufactured and to that end both the WESF inventory and the WSRC inventory would be required to allow sufficient units to be manufactured to make financial business sense.

\section{Decontamination \& Decommissioning (D\&D)}

The Cs-137 stored in the WESF capsules would have to be removed and reencapsulated using the WESF facilities along with upgrades to the facility. If the Cs137 and the facility were privatized for this purpose, the manufacturer would not be willing to take on the final baseline D\&D liability of WESF and take the site back to a green field state. This liability would have to remain with the Government. One way of dealing with this issue is to baseline the facility before it is privatized and require the manufacturer to deal with only the changes/increases to that baseline. This issue is further discussed in section 4.1.1 (Hanford WESF/B Plant Options).

\section{Nuclear Regulatory Commission (NRC) license}

The manufacturer must gain a NRC license for the WESF operation and also must address the operating conditions of such a facility while under NRC license conditions. Since Washington is an agreement state with the NRC, this requires close coordination with the state regulators. 


\section{By-product material}

There is a regulatory issue involved in insuring that the $\mathrm{Cs}-137$ is considered as a byproduct material as opposed to a high level waste. This would have a major impact on both handling and transportation of product and could have severe consequences if not categorized as by-product.

\section{WESF due diligence}

The potential manufacturer would need to have reasonable confidence of costs associated with upgrading and operation of WESF.

\section{Cost Avoidance Financing (CAF)}

The CAF method would have to be implemented along with an understanding of the price per curie of Cs-137 and Strontium that the government is willing to pay for successful removal from WESF and placement into long term storage. This subject will be explored more fully in section 4.1.1 (Hanford WESF/B Plant options).

\section{End of life Cs-137 liability}

The final liability for end of life disposal of the Cs-137 may or may not be an issue, but it needs to be addressed with some understanding between the government, manufacturer and end use customer. As discussed in the video "The GRAY*STAR Solution", the Cs-137 radiation sources are loaded into the lower portion of the GRAY*STAR called the "Graysafe" which itself is a permanent dry storage cask and certified for transportation. To be reloaded, the 165 -ton cask must be returned to the source loading site where it can be reopened. The $\mathrm{Cs}-137$ sources could be reprocessed, the non-radioactive material removed, and additional replenishment Cs137 added. There would be little radioactive material to bury or dispose during the interim replenishment operation.

The following sections will discuss the risk-cost items and then the benefits so that a quantitative judgement can be made concerning the cost-benefit of pursuing the "Cs$137^{\prime \prime}$ food irradiation business. Most of the issues addressed will be supported by the marketing study that is attached along with other publications plus the GRAY*STAR video. 


\section{RISK ITEMS (COST)}

The key risk issues are those issues that would tend to impede the chance for business venture/success. This would include cost and finance concerns, manufacturing constraints, liabilities associated with the business, market acceptance and many others. Some risk issues are directly associated with the use of Cs-137 while others pertain to the food irradiation business as a whole. The issues presented here are by no means complete but are believed to be the most demanding concerns.

\subsection{Public Acceptance}

Public fear of "radiation" is a major roadblock to business success. However, studies have shown that with education, consumer acceptance is very high. A study conducted by the Gallup Organization confirmed that the more consumers know about food irradiation, the more likely they are to desire it for destroying bacteria in poultry, pork, beef and seafood. Although 73 percent of Americans have heard about food irradiation, only 24 percent claim to have any knowledge of the process. Most admit to knowing little about the process, its advantages or potential drawbacks. " Consumers are interested in learning more about any process that improves the safety of their foods," said J.Patrick Boyle, president of the AMI Foundation that funded the study. "The more concerned consumers are about food safety, the more likely they see irradiation as an important and necessary food safety process."

In a simulated supermarket setting study conducted by the University of Georgia, 50 percent of consumers tested chose irradiated ground beef over regular ground beef. After all consumers tested learned more about the irradiation process and how it affects raw meats, those choosing irradiated beef increased to 70 percent of the sample size. " Results of all phases of the consumer studies consistently confirm that the more consumers understand about food irradiation, the greater benefit they believe they gain from irradiated foods."

The whole issue of public acceptance must be met head on with more facts and availability of irradiated food products. The U.S. lags behind the use and acceptance of food irradiation as compared to many other countries. On the positive side, the research shows that this issue will be settled with positive experience and education.

An additional concern with the use of Cs-137 on the public acceptance issue is the fact that it is produced from a by-product of the previous "Government war time mission". The cobalt-60 source suppliers don't have this issue to contend with and will have easier market entry. 


\subsection{Liability/Litigation}

Past problems with Cs-137 usage make long term liability and potential litigation a real issue that must be dealt with in both government and commercial terms. In early June 1988 , the Radiation Sterilizers, Inc. facility in Decatur, Georgia (now SteriGenics) discovered Cs-137 contamination in their storage pool. The activity measurement of pool water taken shortly after facility shutdown indicated approximately 4 curies of Cs137 radioactivity had dissolved in the pool water from a leaking WESF capsule. An additional 2-3 curies was estimated to be elsewhere in the shielded area-primarily on the shroud. Cs-137 continued to leak at a very low rate from the capsule after facility shutdown. Leakage remained at a low rate until November 29, 1988, when capsule 1502 was isolated from the pool water. The total estimated release of Cs-137 from the leaking capsule was 7-8 curies. No evidence of contamination was detected in the immediate surroundings of the facility. Also, no trace of contamination was found on any product or product packaging in customer inventory. This event led to large cleanup costs and legal issues for DOE. The 4 year legal battle over the leaking Cs137 filled capsule from Hanford ended in May 1995 with dismissal of suits. However, the appeal process may not be over. New commercial use considerations could create new litigation and cost liabilities for the Government. As discussed in the marketing study, the Cs-137 safety issue and water solubility issue are major hurdles that make the business use of Cs-137 very risky. Many of the players in this market just don't want anything to do with Cs-137 and think that it could damage the future success of the overall food irradiation market. Cobalt-60 has a clean safety record and doesn't have to face these same issues. It seems clear that Cs-137 source food irradiators would have to have a substantial economic advantage to overcome the emotions linked to its past problems.

The GRAY*STAR design does offer a major technical solution to the issue of water solubility in that it is a total "dry storage" facility. This concept, as discussed in the video (The GRAY*STAR Solution), makes it totally different from previous Cs-137 irradiators in that there is no need for a water pool and the mechanism for this type of failure does not exist. However, past history will be a major hurdle to overcome.

\subsection{Long Term Disposal}

If Cs-137 is encapsulated for new commercial use, there is at present no long term disposal plan in place for either the commercial sector or government. This would have to be addressed as part of the cost to end consumer and the government. As mentioned previously, the "GRAY*STAR" design addresses this problem in part since the "Graysafe" cask is in itself a long term dry storage unit that is transportable and inherently "safe". The issues inherent in the long term disposal question would have to be investigated as part of the potential business development of the "GRAY*STAR". 


\subsection{Cs-137 Inventory - Near Term}

The issue of available Cs-137 near term inventory is of course the key ingredient to potential manufacturing financial analysis for business planning purposes. A source schematic for the potential GRAY*STAR business is shown in figure 3. This illustrates how the present high level radioactive waste liabilities stored at government sites can be separated and converted into useful products under the GRAY*STAR vision. The near term Cs-137 supply includes all single and double shell tanks plus all encapsulated Cs-137 chloride inventory. Plans to vitrify Cs-137 in solution would remove that source of inventory from consideration for commercial use.

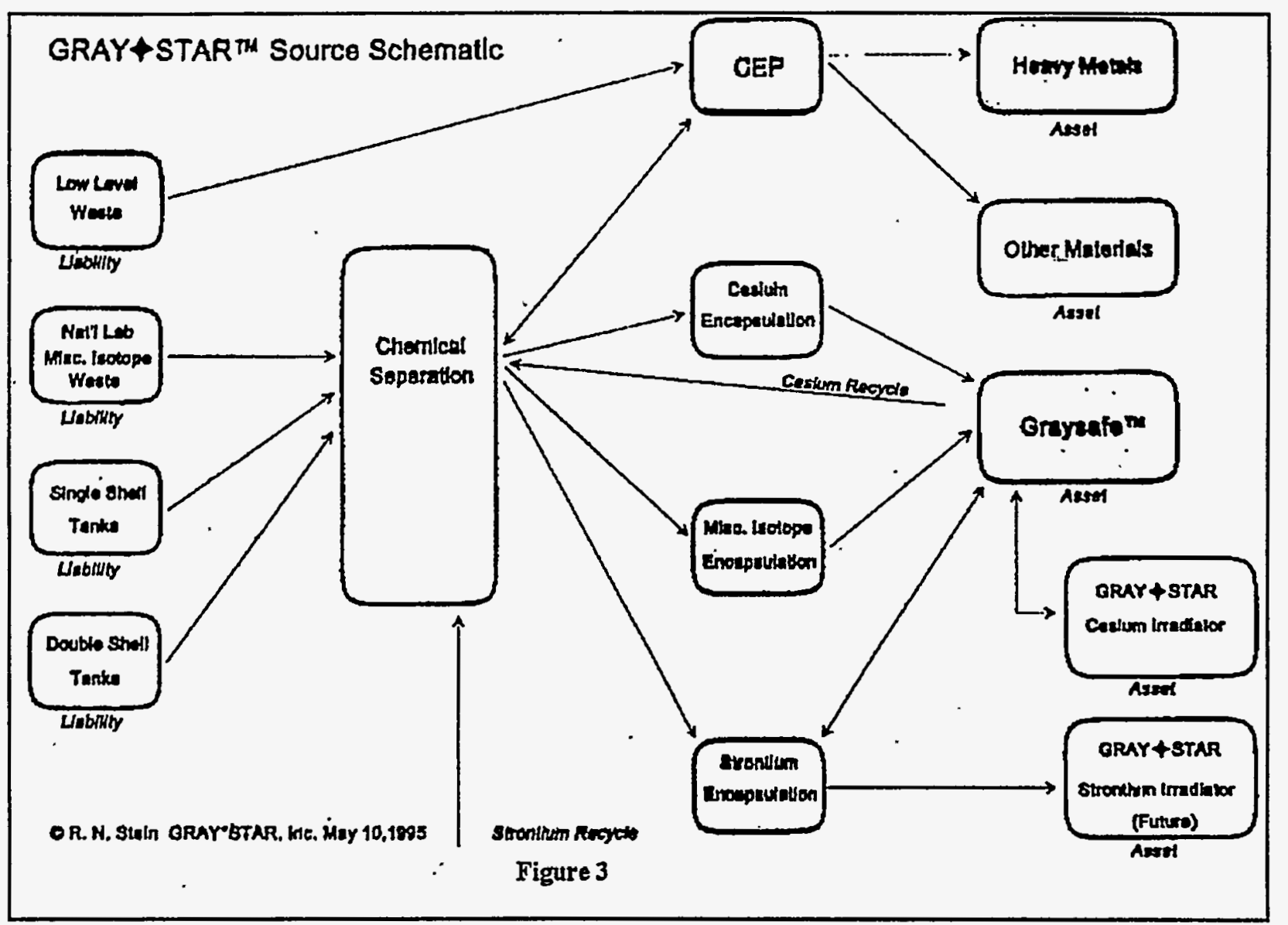

The WESF CS-137 inventory could only supply about 17 food irradiators. The total world wide market potential for food irradiator units ranges from a few hundred (Appendix D, market study for just fruit and vegetables) to a few thousand (based on GRAY*STAR market research). The true number is probably somewhere in between and this requires that the Savannah River Cs-137 in their waste tanks would have to be saved for any near term manufacturing analysis and production cost sharing. Investment costs associated with both processes to save and encapsulate the Cs-137 salt would have to be accounted for in the analysis. 


\subsection{Cost Avoidance Financing (CAF)}

The concept of CAF would have to be analyzed and approved as a way of paying for investment requirements and profit incentive for commercial firms who save government costs by using/retrieving isotopes and changing processes that are presently in place. A summary of the CAF analysis and assumptions associated with the commercial use of the near term Cs-137 inventory at both WESF and Savannah River site will be presented in section 4.1 (cost avoidance).

\subsection{Cs-137 inventory - Long Term}

Cs-137 inventory at Hanford and Savannah River sites would only allow for manufacturing of about 100 food irradiators. With a potential market (according to GRAY*STAR) in the thousands, this requires additional sources. At present there is a potential large supply of $\mathrm{Cs}-137$ in Russia along with the other alternatives (i.e. other foreign supplies, spent fuel processing). These alternatives will not be addressed as a part of this plan. Also, this would be a very difficult political undertaking and would have to be balanced by major benefits.

\subsection{Food and Drug Administration (FDA) Approval}

For regulatory purposes, irradiation of food is treated as a food additive. This requires a long research program before FDA approval is granted for any particular type of food. The FDA has studied the safety and efficacy of food irradiation repeatedly and has approved irradiation several times in the past 30 years for use in preserving and decontaminating a variety of foods (appendix 1). The petition for approval of seafood has been at the FDA for over six years and for beef over one year and these are considered to be under "expedited" schedules. The FDA has not approved the foam tray packaging for chicken for consumer use, even though the research was done in 1960. Also, the maximum exposure limits are much lower in the.U.S. than in other countries making it very difficult to compete. It appears that the FDA hurdles are a main issue to food irradiation business success.

\subsection{Certification/Licensing}

A variety of safety testing and safety analysis must be demonstrated and performed on any new food irradiator design. Before a prototype can be manufactured, the company must prove the unit will not harm the workers, the public or the environment in any way. This process requires a very extensive review by the U.S. Nuclear Regulatory Commission before they will grant an approval. The GRAY*STAR design which still must be reviewed and approved by the NRC is "inherently safe", i.e., it will not emit radiation regardless of the treatment it receives (or doesn't receive). It is a self contained unit which does not have a "safe" or "not as safe" mode. It is physically -impossible for a person to enter the irradiation chamber when the source is "up". Complex and elaborate "in-out" door interlocks are not required. The safety of the unit does not depend on the operator. Also, the accident that occurred with the WESF 
Cs-137 chloride capsule, developing a pinhole leak and contaminating a pool of water in the experimental facility in Georgia (SteriGenics International), can't occur with this design. The GRAY*STAR is a large self contained irradiator and the water pool problem is totally avoided. Also, the design has "passive safety features", i.e., no "active" safety system is required.

There are four categories of NRC licensing related to cesium use as an irradiator. Categories I and II relate to use of radioisotope for irradiation using dry storage and III and IV for wet storage. Cesium salts probably would not be acceptable for use in categories III or IV since the regulations state that sealed sources installed after July 1, 1993 must use radioactive material that is as nondispersible as practical and that is as insoluble as practical. The food irradiator, as proposed by GRAY*STAR, would be either category I or II. Since it is not radiating into a room, it is expected to be category I. As would be expected categories I and II are much less expensive to operate, relative to NRC requirements.

Besides U.S. NRC licensing, the U.S. Department of Transportation (U.S. DOT) requires a special permit specific to a shipping cask which contains radioactive material. The submission to obtain this permit must prove to the DOT, beyond any doubt, that there is no danger of releasing radiation or radioactive material even under the most severe conditions imaginable. The GRAY*STAR unit is its own shipping cask, so once the permit is received it will apply to all units constructed in the future. These licensing activities may require investments of up to $\$ 10$ million depending on requirement negotiations with the respective government agencies.

For the export market, The International Atomic Energy Agency (IAEA) will accept the DOT's analysis so that the units can be shipped internationally. 



\section{KEY DRIVERS (BENEFITS)}

\subsection{Cost Avoidance}

Any idea for the recovery and use of Cs-137 needs to be economically and politically attractive to DOE and its cleanup mission. There are many important considerations supporting food irradiation using Cs-137 that reside outside DOE and the cleanup mission. These include the 6 to 9 thousand deaths per year and approximately 6 million reported illnesses attributed to food-borne disease. Also, the agricultural export market and the cost of imports could be greatly impacted without the food irradiation option. However, a key consideration for DOE is to support the cleanup mission under increasingly tight fiscal constraints. Due to past problems, convincing the Government to reinstate the use of Cs-137 will require certain conditions. The first concern is that the taxpayer should not be burdened with or responsible for liability of a commercial venture. Thus, licensing, permitting, design, and quality responsibility should be borne by the commercial entity. If cost avoidance and cleanup mission requirements are met, DOE should make its resources available. But after that, all aspects of this effort should be transferred to the private sector. At the end of life of the Cs-137 the DOE could allow access to a repository for safekeeping and final disposal. This concept seems to make sense because DOE would also have to do this if it maintains the Cs-137.

In an environment of budget cutting, funds for new projects will be under great scrutiny. Any new project should not impose, by planned or unplanned events, excessive costs to the Government. Nor should additional cost or waste materials be imposed on the cleanup mission. Cost avoidance financing (CAF) has the attributes to satisfy these conditions. The basic concept is to reduce out-year maintenance or operational "mortgage" without a near-term budget increase. Start deactivation of projects earlier by incentivizing private contractor to complete specified work on a fast track. DOE would use the out-year maintenance and operational cost savings from early deactivation as a revenue stream to enable scheduled payments for completing performance based milestones. Likewise a "contractual guarantee" for periodic payments would enable contractor loans for up front investment requirements. For example, the B Plant at Hanford (a large canyon-type facility shutdown in 1985) supports the small Waste Encapsulation Storage Facility (WESF) which stores the Cs137 and strontium capsules. The maintenance "mortgage" for this setup is approximately $\$ 20$ million per year and any reasonable option for early deactivation could show a large cost avoidance for the DOE.

Various scenarios for utilization of the Cs-137 capsules at WESF and recovery of the Cs-137 from the flow stream at Savannah river were analyzed in terms of potential cost avoidance. The expected out year cost stream assuming operations as usual, (i.e. no privatization or commercial use of the Cs-137 inventory) was compared to options converting the Cs-137 to a useful product. These preliminary analyses presented in sections 4.1.1 and 4.1.2 give results that are very favorable to the DOE's effort to cut cost of the cleanup mission while converting a "waste stream" into a useful by-product. For the Hanford WESF, two cases are considered (with and without dry storage) and 
then the comparison is made to the GRAY*STAR option. At Savannah River, four options are examined that consider a variety of technologies to separate the Cs-137 from the flow stream for the Defense Waste Processing Facility (DWPF). A first cut of these cost avoidance calculations are as follows:

\subsubsection{Hanford WESF/B Plant Options}

Since the actual plan for reducing the operation and maintenance cost at WESF where the $\mathrm{Cs}-137$ capsules are located is not yet determined, three plans were reviewed to understand the least cost to the government. To determine the cost effectiveness of Cost Avoidance Financing (CAF) the least cost plan was used to compare total costs versus potential commercialization of the Cs-137 (ala the GREY*STAR option). At present, the three options for "maintaining" the Cs-137 and strontium capsules until the year 2025, the time expected for a permanent storage decision to be made, are as follows:

\section{Wet Storage Option}

WESF is adjacent to $B$ plant and shares some of the utilities and other functions necessary for the present wet storage of the Cs-137 and strontium capsules. The present maintenance and operational costs of this setup are very high and are estimated to be $\$ 20$ million per year. This obviously presents a very large cost mortgage for DOE, and even with WESF isolation in the near future, the cost liability is over $\$ 300$ million which is a very large cost avoidance target. This immediately leads to consideration of other long term storage options.

\section{Dry Storage (Management and Operation, M\&O responsibility) Option}

One way to greatly reduce the costs associated with wet storage is to consider a dry storage possibility in combination with the Spent fuel Canister Storage building (SFCS). The earliest date for operation of the SFCS is 2001 and the schedule for transporting of the cylinder enclosed capsules into this facility would not happen before 2004. This would allow the B plantWESF facilities to be put into a shutdown mode with minimal overhead costs associated with their existence until final decontamination and decommission (D\&D) around 2025. The operations costs associated with the $B$ plant/WESF in the shutdown mode (i.e. all capsules removed) would be about $\$ 1$ million per year until final D\&D. The cost liability associated with this option and assumed schedule is about $\$ 200$ million for DOE.

A potential variation on the dry storage (M\&O) option is to consider the private sector performing the dry storage task. The major leverage in this scenario is the schedule and the associated $\$ 20$ million per year cost avoidance associated with earlier shutdown of the $B$ plant/WESF facility. The cost avoidance would then be used to finance the private sector and reward it on an incentive basis. Figure 4 shows a comparison of the dry storage ( $\mathrm{M} \& \mathrm{O}$ ) option and an assumed private sector storage option with completion date of 1999 . Assuming a $\$ 30$ million payout to the private 
sector for the dry storage task, this variation would cost DOE approximately $\$ 120^{\circ}$ million. As can be seen here, meeting schedule is the key to cost savings.

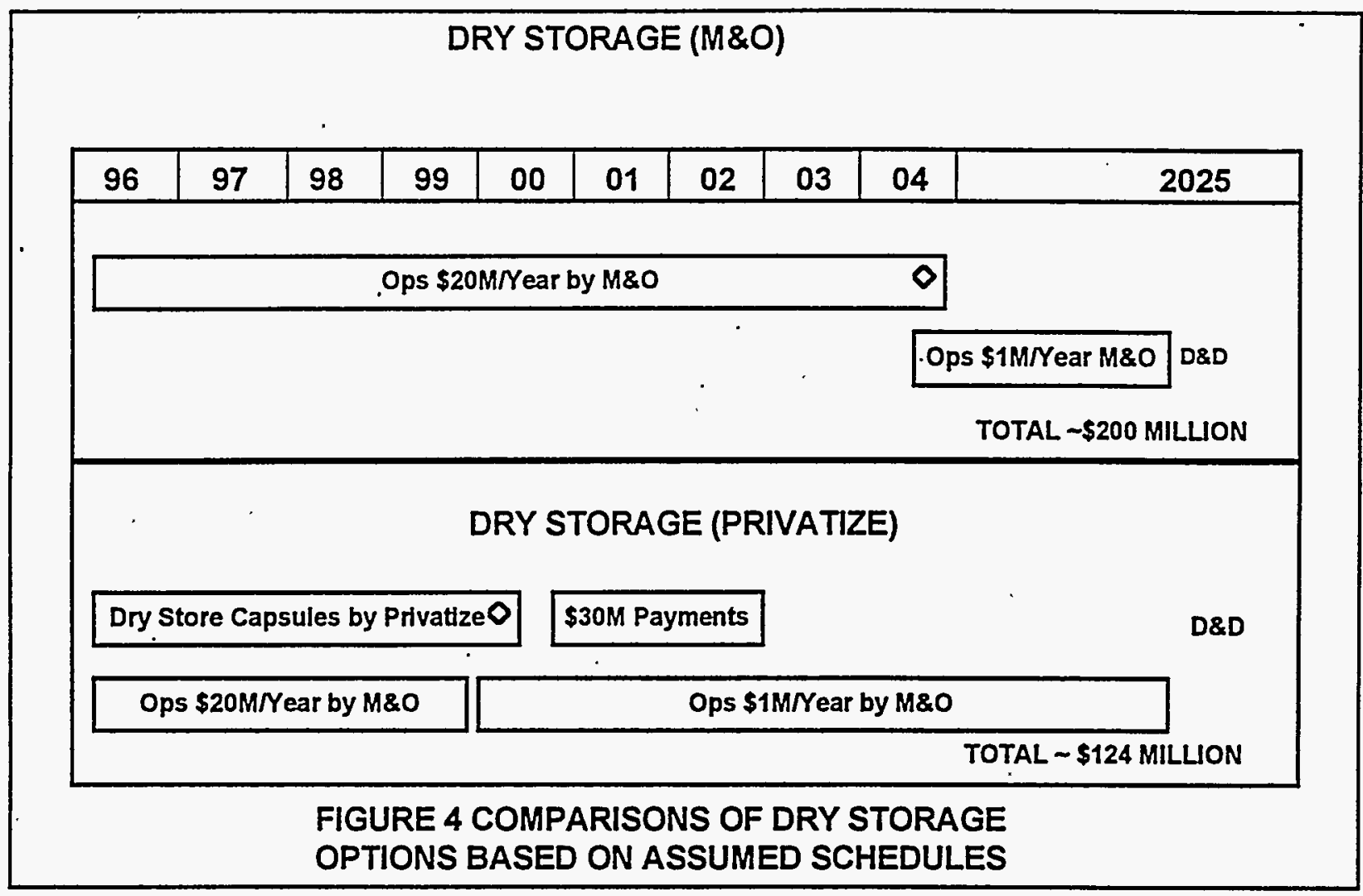

The GRAY*STAR Option

The food irradiation option could be implemented a variety of ways, however a number of tasks would be constant. These would include:

${ }^{*}$ Research and development of new capsules and encapsulation process

*Isolation from B plant

*Privatize WESF operation and refurbish for required encapsulation process and loading process into GRAY*SAFE

*Dry store strontium

*Shutdown facilities for minimum O\&M costs

The private sector manufacturer would be paid for these accomplishments based on his performance on a cost savings initiative. Obviously the quicker the manufacturer can re-encapsulate the Cs-137 and install it into the GRAY*SAFE units, the greater the amount of cost avoidance realized by the government. This would determine the payback to the private sector to cover required investment costs plus profit incentive. A potential timeline for cost calculation purposes is shown in figure 5. This timeline assumes isolation from $B$ plant is completed by mid 1997 along with required upgrades to WESF. The manufacturer would then complete re-encapsulation and loading of Cs- 
137 by early 1999 . The cost of this option would be approximately $\$ 100$ million to the year 2025 which also assumes operational costs of $\$ .5$ million per year after shutdown. In this scenario, the private company would receive approximately $\$ 60$ million for completing all initiatives as scheduled.

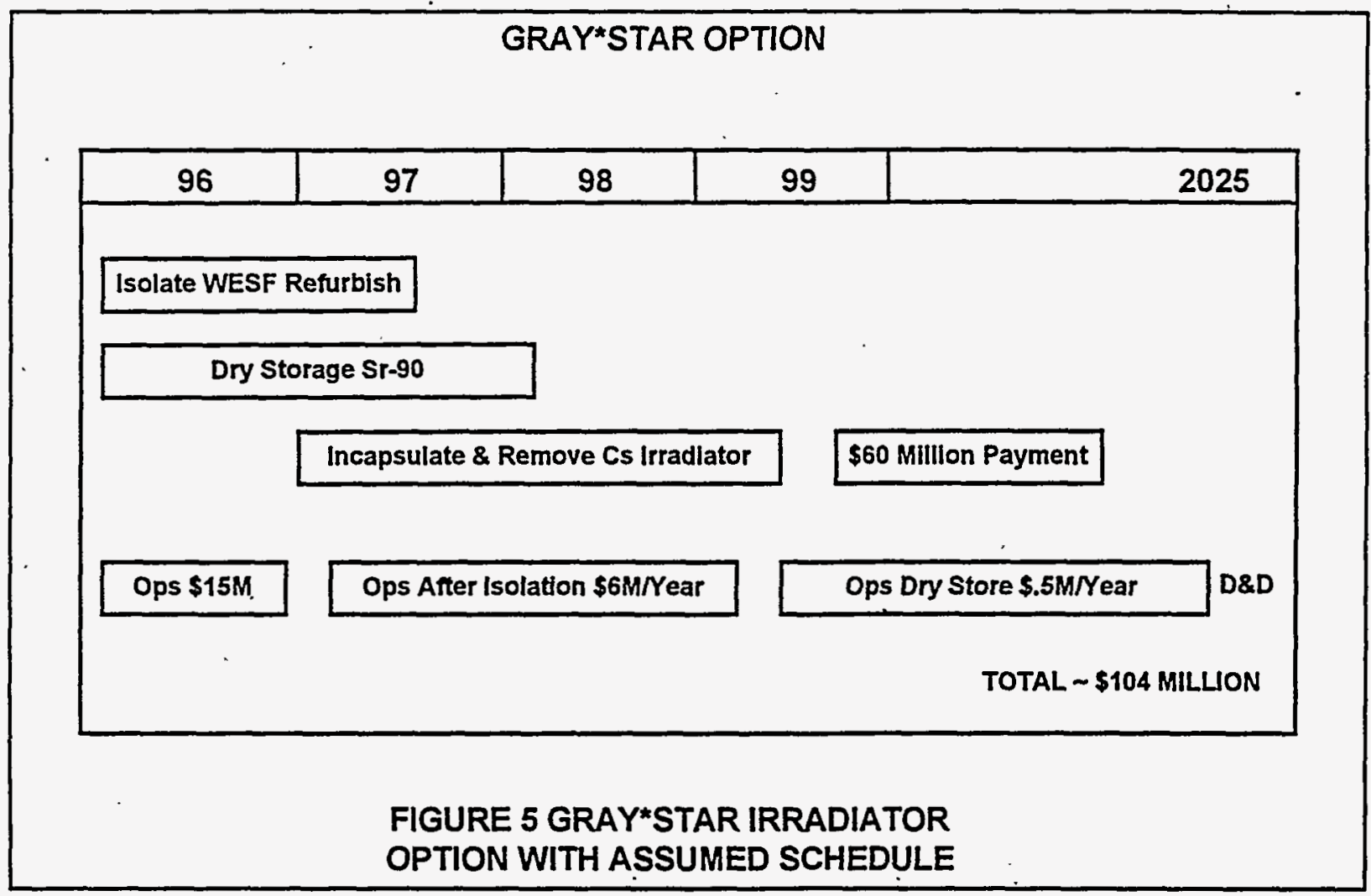

The lease agreement for the WESF facility will include a formula for cost sharing the $D \& D$ activities at the end of mission. It is envisioned that a survey is made prior to privatization that will set the baseline for the government obligation. A decay model might be used to adjust the baseline for time. The lessee would be responsible for levels above the baseline as a percentage of the D\&D cost or might be responsible for reducing the level of activity to adjusted baseline and the government would be responsible for all D\&D. These types of details for commercial operation would obviously have to be part of any negotiated contract. However, using this timeline for a cost avoidance premise it can be seen that this commercial endeavor would save the government approximately $\$ 20$ million to $\$ 100$ million over the dry storage option, and of course much more compared to the present wet storage activity. 


\section{Cost For Curie Of Cs-137 Encapsulated Calculation}

The assumption of the above mentioned $\$ 60$ million Cost Avoidance Financing (CAF) for the private sector would be included along with the total cost to re-encapsulate the WESF Cs-137 capsules to calculate the approximate net cost for curie of Cs-137. A first cut approximation on the procedures and costs for Cs-137 encapsulation was provided by Pacific Northwest National Laboratory (PNNL). This information, included in Appendix $A$, contains procedures for barium removal from the material extruded from WESF Cs-137 capsules, followed by re-encapsulation of the Cs-137 into capsules with the GREY*STAR design for food irradiators. Also attached is a spread sheet that details the costs for re-encapsulation of all the Cs-137 in the WESF facility. This particular case study based on fully burdened labor cost shows a total cost per curie to be approximately $\$ 1.30$. With the assumption of $\$ 60$ million CAF, the net cost of the Cs-137 would be $\sim \$ 0.30$ per curie. As seen previously, this would allow the GRAY*STAR option to be quite cost competitive in many market segments. This is just for illustration and assumes many scheduler and CAF details.

\subsubsection{Savannah River Site Options}

This information does not represent the position of Westinghouse Savannah River Company (WSRC) and is to be used for planning purposes only. Considerable work is needed to determine technical plausibility and to refine estimates of costs and savings. There is no money currently available to make any of the modifications discussed here.

Included are estimates of the costs and schedules of recovering Cs-137 from Savannah River Site (SRS) supernate via the two process options discussed. In generating these estimates, it is assumed that the Cs-137 would be turned over to a private company, who would perform the encapsulation.

\section{SUMMARY SRS Cs-137 Recovery}

The idea of recovering Cs-137 from the supernate is promising. It could:

* Generate cost savings for DOE

* Help DOE realize its goal of privatizing SRS work, and

* Benefit the American agriculture and meat industry by providing inexpensive irradiation that will help them compete in the global economy

* Convert a wartime mission flow stream into a product for beneficial reuse

* Reduce the amount of High Level Waste stored in the Federal Repository

All of the options considered would generate considerable savings for DOE in the outyears. A large saving would be realized near the end of Defense Waste Processing Facility (DWPF) life because the number of canisters could be reduced. Estimated savings are in the neighborhood of $\$ 500$ million from being able to shut down DWPF early and $\$ 150$ million in reduced cost for disposal of canisters in the repository. A 
savings of $\$ 10-15$ million/year could also be realized if option B is selected (Replace ITP and the DWPF Salt Cell with an lon Exchange Process) by not running the salt cell and not having to purchase sodium tetraphenylborate. However, this option involves much more capital cost and impact on schedules.

The most promising option, removing the Cs-137 from the Precipitate Hydrolysis Aqueous product in the DWPF, would have very little impact on schedule and only modest costs for construction of the new facility. The biggest barrier to proceeding with any of the options is that they require capital outlays now to reduce operating costs later.

\section{DESCRIPTION OF OPTIONS CONSIDERED}

The two major options for removing the Cs-137 from the waste are as follows:

A. Recover the Cs-137 from the Precipitate Hydrolysis Aqueous (PHA) stream in the DWPF and provide the recovered Cs-137 to a private contractor. The PHA stream is the cesium-rich stream from the DWPF salt cell that is mixed with the waste sludge and (after some further processing) sent to the glass melter. In this option, IPT and the DWPF salt cell are operated per the current operating plan, so there are minimal impacts to facility startups and plans. Instead of sending the PHA to the melter, the sodium titanate solids in the PHA would be allowed to settle out, then the liquid PHA would be sent to an ion exchange process where the Cs-137 would be recovered and made available to a private company for encapsulation as a gamma source.

A.1 A variant of this option would be to sell the entire PHA-organics, potassium, and all-to a private company

B. Replace ITP and the DWPF Salt Cell with an lon Exchange Process. This is an option that has been studied extensively at SRS. In this option, ion exchange is used to separate Cs-137 from Tank Farm supernate. The cesium is eluted (perhaps as CsCL2) and provided to a private company.

B.1 A variant of this option is to run ITP for a few years to allow some salt removal, but replace Salt Cell with an ion exchange process. The small amount of precipitate produced by the initial runs of ITP would be fed directly to the melter cell without being hydrolyzed (the glass melter has the ability to handle small quantities of organics, about $10 \%$ of the amounts produced by the ITP process at design rates).

The high-spot costs and schedules from the two main options and variants are presented in Appendix B. 
A summary of the potential cost avoidance at the 2 sites is as follows:

Hanford WESF/B Plant: $\sim \$ 300$ Million direct (no dry storage) OR

$\sim \$ 20$ Million to $\$ 100$ Million direct (dry storage).

Savannah River: $\sim \$ 500$ Million direct (early shutdown DWPF) PLUS $\sim \$ 150$ Million direct (reduced canister disposal at federal repository)

\subsection{Food Borne Disease}

Foodborne diseases pose a widespread threat to human health and are an important cause of reduced economic productivity. Studies by the Centers for Disease Control and Prevention show that foodborne diseases caused by pathogenic bacteria such as Salmonella, E coli and Campylobacter, and by parasites such as Trichinae (pork) and Aniskasis (fish), cause an estimated 7000 deaths and from 24 million to 81 million cases of diarrheal disease annually, (see appendix C). The U.S. Department of Agriculture estimates that annual medical and lost productivity costs associated with selected foodborne pathogens are between $\$ 5$ billion and $\$ 6$ billion. This is an indirect cost to the taxpayer or U.S. economy.

Food irradiation, like pasteurization of milk, can prevent countless infections because it destroys the pathogens that cause foodborne illness. For example, 1.5 to 3.0 kilograys (kGy) kill between $99.5 \%$ to $99.9 \%$ of Salmonella, Pseudomonas, Achromobacter, and Lactobacillus organisms on poultry carcasses. Food irradiation will not introduce changes or cause nutrient losses in the composition of the food. In 1993, the American Medical Association's Council on Scientific Affairs affirmed food irradiation as a "safe and effective process that increases the safety of food when applied according to governing regulations."

\subsection{Fresh Produce Life Extension}

Exposure to gamma irradiation can retard the maturation, senescence, and sprouting of fresh fruits and vegetables, increasing their shelf lives and decreasing post harvest loss. An effective measure to increase the availability and consumption of fresh fruits and vegetables, irradiation produces no toxic residues in food and maintains the nutritive and sensory qualities of treated foods. As an example, the shelf life of strawberries will be increased five weeks while onions and potatoes are prevented from sprouting for many months. This increases the flexibility of the major agricultural producers to sell their output to the U.S. consumer and can help the balance of trade by cutting back on import needs. 


\subsection{U.S. Agricultural Export Market}

Export of fresh produce is a major growth business in the U.S. The produce from many areas have to be treated to satisfy the regulations on plant protection and quarantine in importing countries such as Australia, Japan, New Zealand and others. Fumigation by ethylene dibromide or methyl bromide is often used to rid quarantine pests from the produce. However, these chemicals have either been prohibited or their use restricted because of health, environmental or occupational safety reasons. Methyl bromide was recently implicated as one of the substances which deplete the ozone layer. Its use is being phased out by the year 2000 under the Montreal Protocol - an international treaty for the regulation of ozone depleting substances worldwide. Under the U.S. Clean Air Act, the production and consumption of this chemical will be terminated in this country not later than the year 2000 .

Without methyl bromide, trade in fresh produce could be in jeopardy as most other treatments to satisfy quarantine regulations are either pest or commodity specific. Irradiation is considered the strong leading candidate to replace the use of methyl bromide to overcome quarantine barriers. A single dose of irradiation, i.e. 150 gray $(G y)$, can effectively prevent the emergence from fresh produce of fruit flies, the most destructive pests which are quarantined in many countries. A higher dose, $300 \mathrm{~Gy}$, will ensure sterility of other quarantine pests. Regional plant protection organizations including North American Plant Protection Organization (NAPPO), European and Mediterranean Plant Protection Organization (EPPO), Asian and Pacific Plant Protection Commission (APPPC), Comite de Sanidad Vegetal del Cono Sur (COSAVE), Organism International Regional de Sanidad Agropecuaria (ORISA), etc which operate within the framework of the International Plant Protection Convention, have endorsed the use of irradiation as a quarantine treatment of fresh produce. The GRAY*STAR option for food irradiation will help give flexibility to the agricultural business community and help insure their role in the growing export market in the next decade.

\section{5 import Treatment Costs}

With the adoption of the Sanitary and Phytosanitary Agreement and measures through the GATT Uruguay Round on Multilateral Trade Negotiation, trade in fresh fruit and vegetables is expected to increase globally. The positive conclusions of the meetings will pave the ground for approval of irradiation as a broad spectrum quarantine treatment to overcome barriers to import of fresh produce. The economic benefits of this treatment could be considerable. A study conducted by the USDA Economic Research Service in 1993 showed the potential benefit of irradiation to replace the use of methyl bromide for only five commodities imported into the U.S. would amount to over $\$ 500$ million for the five year period investigated. Globally, irradiation of various types of food is gaining wide acceptance. Thirty seven countries are using this technology for treating food products including fruits, vegetables, grain, spices, poultry and seafood for commercial purposes and the number of countries and the quantity of food treated is increasing. 


\subsection{High Level Waste Storage}

The conversion of Cs-137 into a useful commercial by-product will reduce the amount of High Level Waste stored in a federal repository. For example, recovering the Cs-137 from the supernate at the Savannah River Site would allow sooner shutdown of Defense Waste Processing Facility (DWPF) and reduce the number of canisters. Estimated savings are in the neighborhood of $\$ 150$ million in reduced costs for disposal of canisters in the repository.

\subsection{New Business (Increased U.S. Competitiveness)}

Most food irradiation plants throughout the world use Cobalt-60 as the irradiation source. The cobalt is foreign supplied and does not allow for fully integrated manufacturing and sales by a U.S. commercial firm. The GRAY*STAR design would allow U.S. manufacturing to compete on the world market utilizing U.S. supplied isotopes while also helping the cleanup mission of Department of Energy (DOE). This is a business that the U.S. does not presently compete in and the estimates of the future world market are very large. Assuming that the Cs-137 market study and the GRAY*STAR market forecast give lower and upper estimates, a potential market of approximately $\$ 4$ billion to $\$ 10$ billion in sales of Cs-137 food irradiators may exist over the next 30 years. 


\subsection{CONCLUSIONS OF MARKET STUDY}

A few of the key findings as a result of the Joyce \& Associates and GRAY*STAR market studies plus internal research are as follows:

* There are enormous drivers for the growth of the world-wide food irradiation market including food borne disease prevention, fresh produce life extension, U.S. agricultural export market, food import treatment costs, insect prevention and others.

* The market studies estimate a potential market of approximately $\$ 4$ billion to $\$ 10$ billion in sales of Cs-137 food irradiators may exist over the next 30 years.

* Many chemicals including methyl bromide presently used for quarantine controls (to prevent emergence of fruit flies in fresh produce for example) are being prohibited and phased out under the GATT treaty by the year 2000 and irradiation is indorsed as the most viable option for food treatment.

* Public acceptance of irradiated food products has been found to be very high with education and understanding of benefits. Irradiated food products are wide spread in Europe and many other countries. Also, the American Medical Association totally endorses food irradiation.

* Past liability issues with Cs-137 probably require a dry storage concept for successful market penetration. Most present food irradiators use Co-60 and are supplied by the Nordion corp., a Canadian firm. This firm is also looking into a Cs-137 food irradiator design.

* The GRAY*STAR design is a dry storage mode, inherently safe design (no active safety systems required such as water pools or forced air cooling). The design includes loosely packed Cs-137 arrays that maintain their integrity with passive convective cooling through all modes of operation. This batch design appears to be cost competitive for low to medium agricultural sales and low throughput meat and poultry sales. Multiple units can also be operated in parallel for higher throughput.

* Food and Drug Administration approval for food irradiation is required for new food items (including hamburger and foam tray packaging for example) and can be a main hurdle to business success in the U.S.

* The Joyce market study cited an early estimate that cost of encapsulation for Cs-137 should be $\$ 1 / \mathrm{Ci}$ instead of " $\$ 7 / \mathrm{Ci}$ " in order to compete in the market with Co-60. Present analysis indicates that the $\$ 1 /$ Ci or lower is achievable for the WESF Cs-137 inventory. 


\subsection{DECISIONS AND ACTIONS}

The preceding sections of this business plan attempted to describe in a factual way the emotional issues, the risks and the benefits that must be considered and weighed as part of the Cs-137 source supplied food irradiation business. As stated earlier, this is a complex situation with a multitude of market issues and the Government needs to apply the appropriate attributes to the risks and benefits and determine the best path for the country. If the decision is made to proceed with or further investigate this potential business opportunity, the following (non inclusive) decisions and actions need to be initiated in a timely fashion:

* Determine the lifetime cost associated with the baseline plan(s) for storage. maintenance, and disposal of Cs-137 at the Hanford and Savannah River sites.

* Investigate and develop technical and management operation options to reuse WESF and DWPF Cs-137 inventory for use in commercial application.

* Determine the lifetime cost associated with the Cs-137 reuse options.

* If the cost differential and other benefits justify reuse, establish Cost Avoidance Financing (CAF) to cover up-front investment requirements and incentive to commercial business.

* Identify and accommodate the manufacturing constraints and long term liability issues to insure that a private company can accept inherent risks in pursuing this business.

* Expedite Food and Drug Administration (FDA) approvals for additional food products and also more flexible maximum exposure limits so the U.S. can compete worldwide.

* Expedite the licensing review process by the Nuclear Regulatory Commission and Department of Transportation on the new Cs-137 food irradiator design (GRAY*STAR). 



\section{APPENDIX A}

\section{CS-137 RE-ENCAPSULATION PROCESS AND COST}

This appendix was produced by the following Pacific Northwest National Labortory (PNNL) staff: Mr. Hurshal G. Powers, Dr. Garth L. Tingey, Mr. David J. Oakley, and Dr. Thomas S. Tenforde. The funding source was provided under the Department of Energy Environmental Management (DOE/EM) contract with PNNL, DE-AC06-76RLO 1830, and PNNL is operated for the DOE by the Battelle Memorial Institute. 


\section{A Conceptual Process for CsCl Irradiator Capsule Fabrication}

The typical method of producing cesium irradiator sources involves a number of steps. Reconfiguration and re-encapsulation of ${ }^{137} \mathrm{CsCl}$ salt from WESF capsules for various commercial irradiator capsule designs requires: 1) removal of the outer capsule, 2) opening the inner capsule, 3) removal of the CsCl salt, 4) barium removal (optional - requires multiple chemical treatment steps as discussed below), 5) reconfiguration of salt to achieve required dimensions, density, etc., 5) loading the $\mathrm{CsCl}$ salt into a custom-designed inner capsule, 5) inner capsule closure weld and inspection, 6) survey/decontamination of outer surface of inner capsule, 7) loading inner capsule into commercial design outer capsule, 8) outer capsule closure weld and inspection, and 9) survey/decontamination of outer surface of outer capsule.

Prior experience exists with $\mathrm{CSCl}$ salt removal and reconstitution of powder into cold pressed pellets, and a number of problems have been identified. Some of the fines from the powder required for cold pressing of pellets become airborne causing major contemination problems within the hot cells and uptake into the HEPA filters, which then raquire large maintenance costs. Because of the high gamma activity and dispersibility, safety analysis studies resulted in placing an 800 gram limitation on open (dispersible) CsCl powder in the 324 shielded material facility (SMF).

The problem of ${ }^{137} \mathrm{CSCl}$ powder dispersibility can be substantially overcome by direct extrusion of salt cores at an elevated-temperature solid state, thereby eliminating any powder grinding/milling operations. This would also permit the processing of much larger batches than is feasible with the cold-pressed pellet process, greatly reducing the time and cost associated with fabrication of custom sources for commercial irradiators.

The conceptual design of a process for producing CSCT salt cores of the necessary quality by eleyated temperature extrusion is described as follows: 1) receive WESF capsules into 324 SMF, 2) remove end caps from inner capsule, collecting end caps and loose salt in a catch bucket, 3) load assembly vertically into upper end of a die cavity, 4) salt cores in some assemblies. may be loose enough to slip into the die cavity, 5) if salt does not move freely into the die cavity, heat the assembly using a clam shell furnace or other heating device to a temperature sufficient to soften or liquify salt at or near the cladding interiace so as to release the salt core into the die cavity (the die cavity may be sized to contain several WESF salt cores and would be designed to accommodate extrusion of salt cores of the required final configuration), 6) extrude $\mathrm{CsCl}$ salt cores of required configuration, 7), after cool down of the salt cores, remove them from the extrusion exit chamber, 1 ) inspect and load salt cores of acceptable quality (i.e., cores having the appropriate weight per unit length, etc.) into inner capsule, 9) inject helium, which is used as the source for the helium leak test, 10) remove CsCl

${ }^{1}$ Extrusion of $\operatorname{CsCl}$ salt cores directly into an inner capsule is not recommended without the benefit of experimental test data because of potential difficulties with control of weld zone contamination. 
isolation seal from inner capsule closure weld zone, 11) insert end cap, 12) perform end cap closure weld, 13) survey/decontaminate external surface of inner capsule, 14) inspect capsule and closure weld (helium leak test, visual, dimensional, gamma scan sample inspection), 15) load inner capsule into outer capsule, 16) inject helium, 17) insert end cap, 18) perform final closure weld, 19) survey/decontaminate external surface of outer capsule, 20) inspect capsule and closure weld (helium leak test, visual, dimensional), and 21) load completed capsule into cask for transport out of 324 SMF.

Residual salt would be rinsed from WESF tubes and end caps using deionized water. Loose salt granules from step 2 of the conceptual process description would also be dissolved in deionized water. The resulting salt water would be evaporated at a specified temperature and the salt cake residue would be recovered for addition to the salt core batch at step 5.

Mechanical properties data have been developed ${ }^{2.3}$ (see attached Figures 3, 4, and VIII reproduced from referenced reports) which support the elevated temperature extrusion concept; however, a process development effort will be. required to establish critical process parameters and detailed equipment design. Excluding barium removal, a two year lead time would be required for equipment design, procurement, and cold demonstration of the process at an estimated cost of $\$ 4 M$ ( $\$ 3.3 \mathrm{M}$ operating and $\$ 700 K$ CENRTC $^{4}$ ). Design of the cold demonstration process would be such as to be scalable to a 6MCi per year production capacity.

If barium removal were required, the salt cores would be removed from WESF capsules directly into a dissolution vessel. CsCl salt would be dissolved using deionized water, and barium would be removed using the ORNL process. Following barium removal, the solution would be evaporated at a specified temperature and the salt cake residue would be recovered for addition to the salt core batch at step 5. The laboratory scale $\mathrm{Ba}$ removal process used at ORNL consisted of the following process operations:

1. Dissolve $\mathrm{CsCl}$ in deionized water.

2. Adjust $\mathrm{pH}$ of solution, using $1 \mathrm{MHCL}$, to between 3 and 10 .

3. Precipitate $\mathrm{BaCO}_{3}$ by reacting the barium in solution with $\left(\mathrm{NH}_{4}\right)_{2} \mathrm{CO}_{3}$.

4. Filter to remove solids.

5. Wash separated solids with deionized water to remove residual $\mathrm{CsCl}$; add wash solution to filtrate solution

6. Check, and if necessary, adjust $\mathrm{pH}$ of filtrate and wash solution to between 3 and 4 . (Add $3 \mathrm{MHCl}$ until a $\mathrm{pH}$ of 6 to 7 is reached; then add $1 \mathrm{MHCl}$ until a $\mathrm{pH}$ of 3 to 4 is reached.)

2J.A. Griffiths, F.A. Simmonen, G.D. Marr, "Elastic Plastic Response of the CsCl Waste Storage Inner Capsule Under Loading Due to Phase Transformation of the CsC1", SAM-79-04, December, 1979, Battelle Northwest Laboratories, Richland, WA

${ }^{3}$ H.T. Fullam, "Thermal Expansion Studies on Pure CsCl and CsCl-KCl-NaClRbCl Mixture", Letter Report, August, 1979, Battelle Northwest Laboratories, Richland, WA

${ }^{4}$ Capital equipment not related to construction. 
7. Heat solution to remove alt constituents which are volatile at $400^{\circ} \mathrm{C}$. Solution is initialiy heated to $100^{\circ} \mathrm{C}$. When solids begin to form, the temperature is lowered to avoid splattering. After the material is sufficiently dry, the temperature is raised to $400^{\circ} \mathrm{C}$ to destroy any residual $\mathrm{NH}_{4} \mathrm{CT}$.

Salt from Step 7 would be an acceptable feed for the CsCl elevated temperature extrusion process. In the ORNL process, CSCl was processed manually in 500 gram batches using $1000 \mathrm{~mL}$ tantalum beakers and typical laboratory equipment. Vapors from evaporation of the filtrate and wash solution were treated by means of an off-gas scrubber to remove HCl from the effluent gas stream. Materials of construction, containment design, off-gas treatment, feed control, instrumentation, and materjals handing are all factors which must be addressed in the development of a hot cell pilot or production scale process based upon the ORNL laboratory scale process. The development of a production process for removal of barium from $\mathrm{CSCl}$ for use in commercial irradiator sources also requires a lead process development commitment. It is estimated that such a commitment would be on the order of eighteen months to two years. of lead time for equipment design, procurement, and cold demonstration of the process at an estimated cost of $\$ 2 M$ to $\$ 3 M$. As with the extrusion process, it is proposed that the design of the cold demonstration process for barium removal would be such as to be scalable to a $6 \mathrm{MCj}$ per year production capacity.

The current Greystar source pencil has a CsCl salt column $44^{\prime \prime}$ in length by $.720^{\prime \prime}$ in width by $3^{\prime \prime}$ in depth. The radius of curvature at the corners of the rectangular cross section (i.e. the $.720 "$ by $3^{\prime \prime}$ cross section) is equal to $0.360^{\prime \prime}$. The volume (V) of the salt column is:

$$
V=(3-.72)(.72)+\left((\pi)\left(.72^{2}\right) / 4\right)(44)=90.15 \mathrm{in}^{3}(1477.2 \mathrm{cc})
$$

Assuming a $\mathrm{CsCl}$ bulk density of $2.8 \mathrm{~g} / \mathrm{cc}$, the weight $(W)$ of each salt core would be:

$$
W=(2.8)(1477.2)=4,136.2 \text { grams }
$$

The average salt weight in the WESF capsule is about 2600 grams, therefore .6286 capsules of the Greystar design would be produced from the salt content of a WESF capsule. A nominal feed capacity of 150 WESF capsules per year ( 3 capsules per 40 hour week) would produce 94 ( 1.9 per 40 hour week) capsules of the Greystar design.

The process footprint, manning, and equipment complexity, and hence the costs of development and operation, are sensitive to the source capsule throughput rate. The preliminary cost estimates provided herein are based upon the above described Greystar design.

Cost and schedule estimates provided herein are preliminary and are subject to change as design changes, further studies, and test data developed during the normal progression of proposal development, process development, and project activities become available.

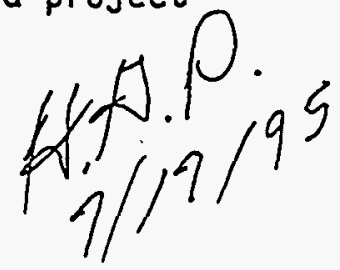




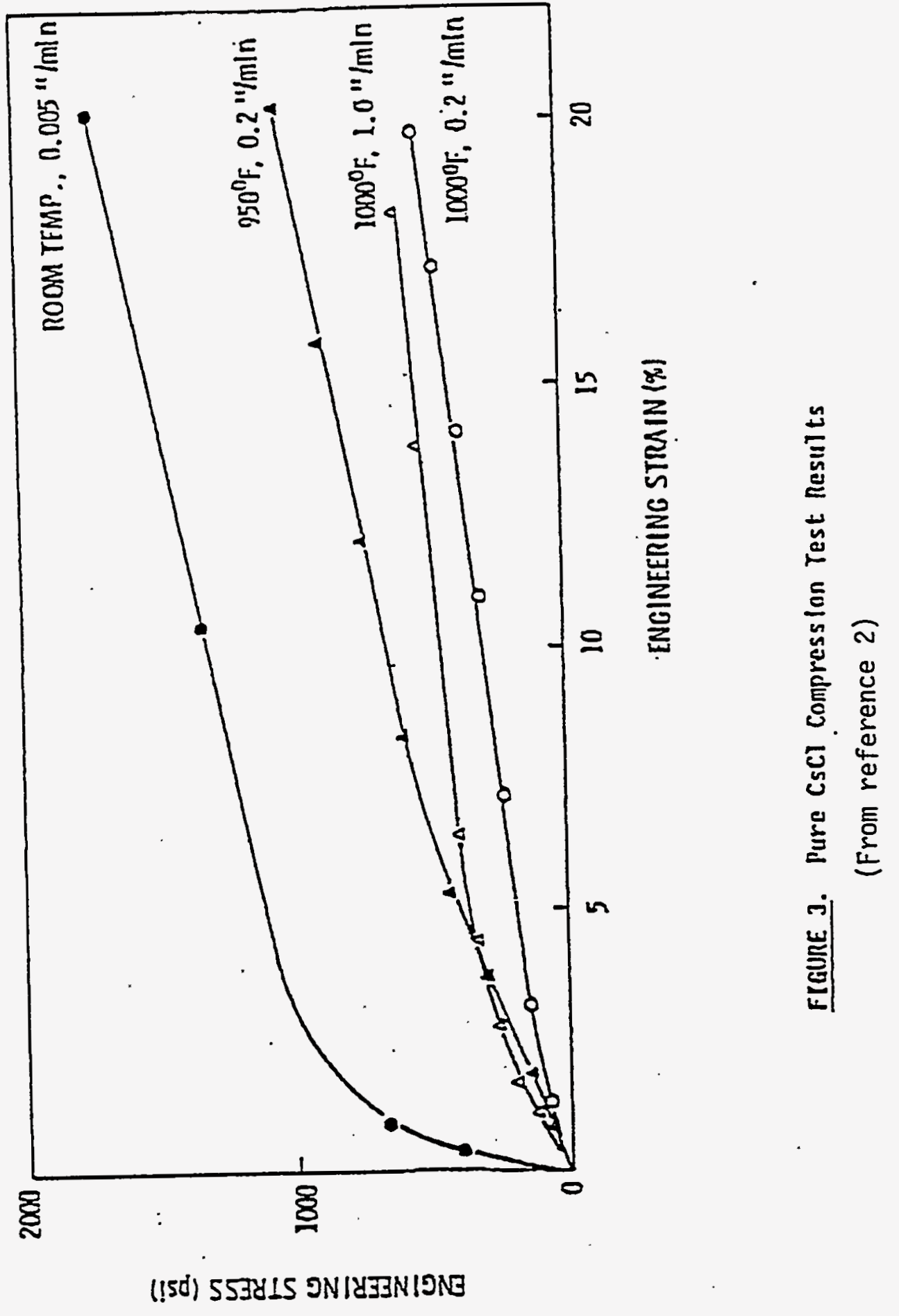




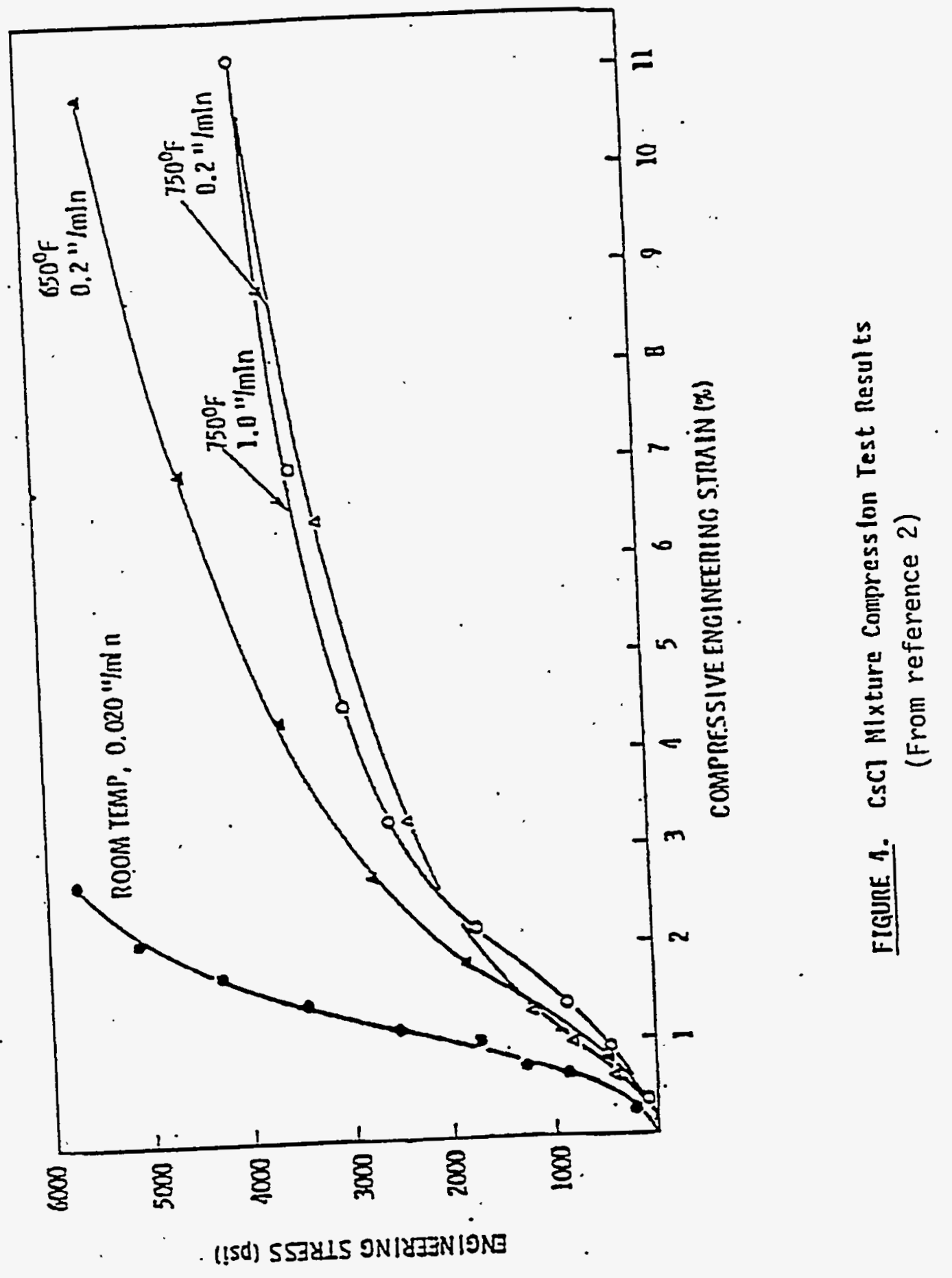


$3 / s^{\circ} I 0$
14010

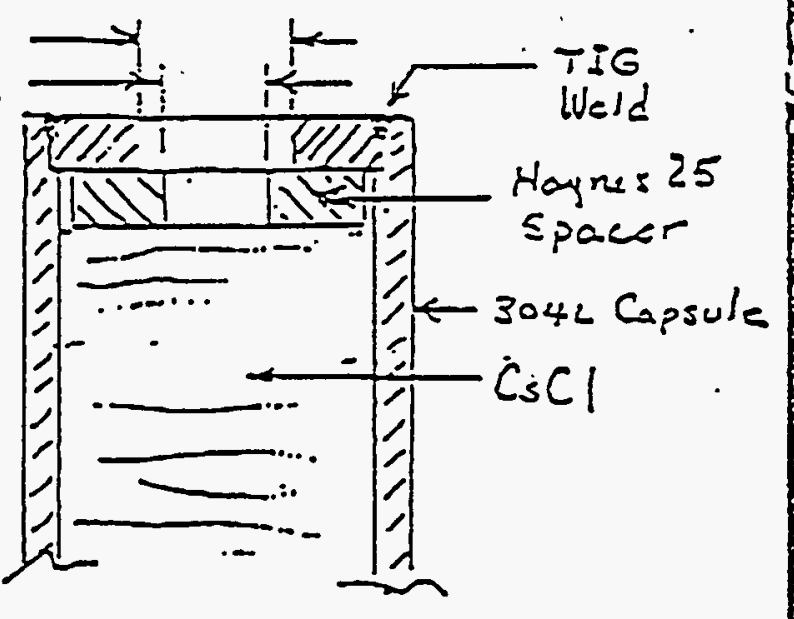

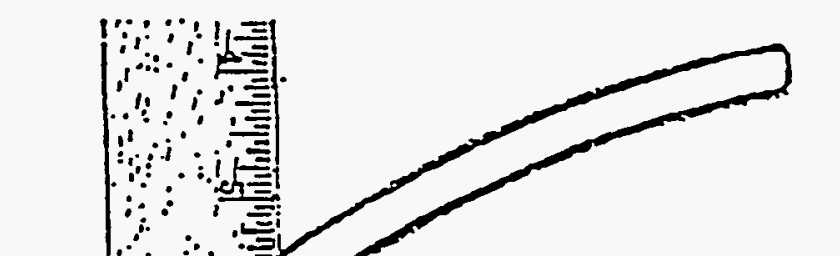

Figure VIII Capsule Showing the Extrusion - of CsCl Which Occured then The Capsule Was Heated to 530 C.

(From reference 3 ) 


\section{$\mathrm{CsCl}$ Capsule}

Fabrication Flow Chart

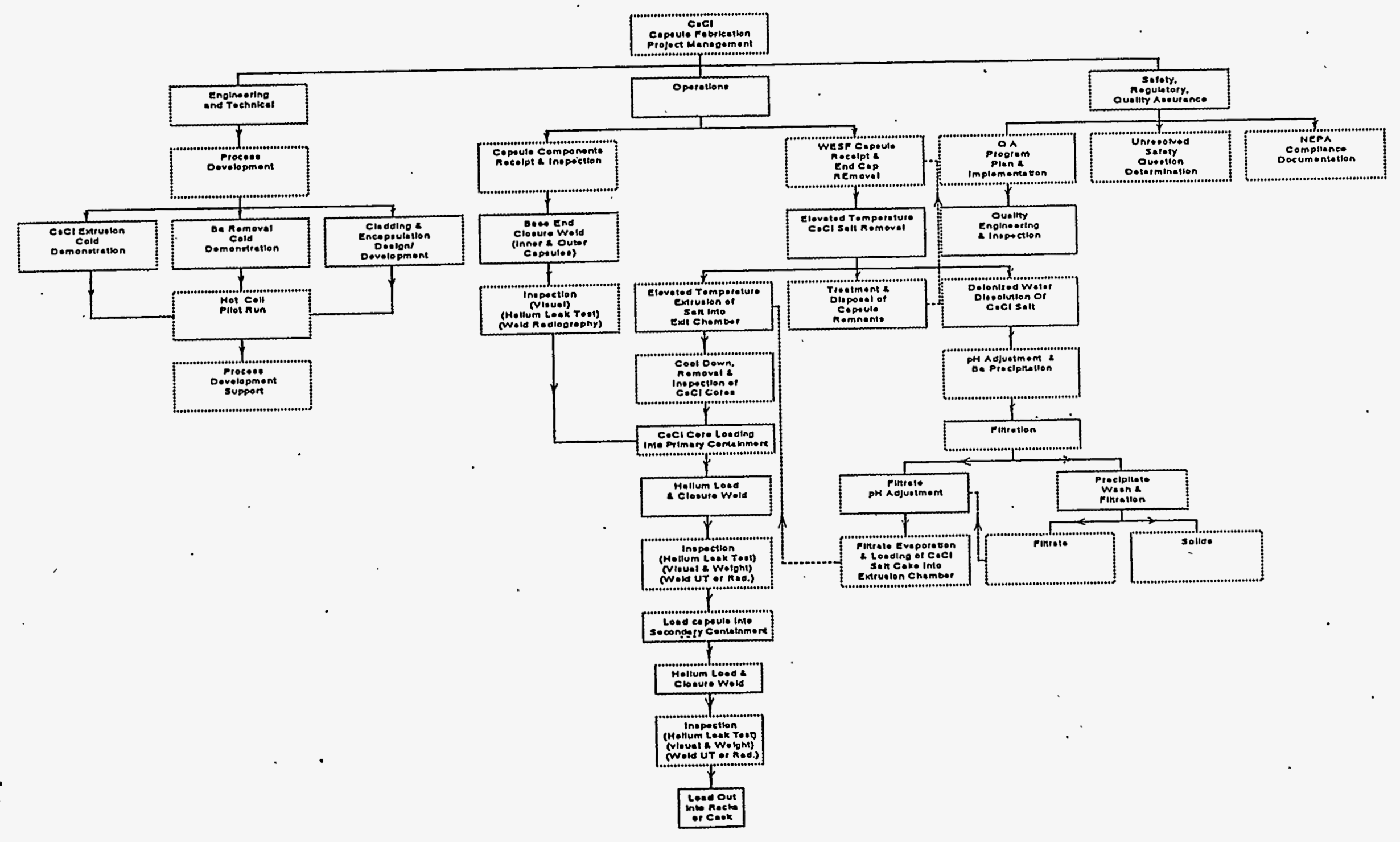



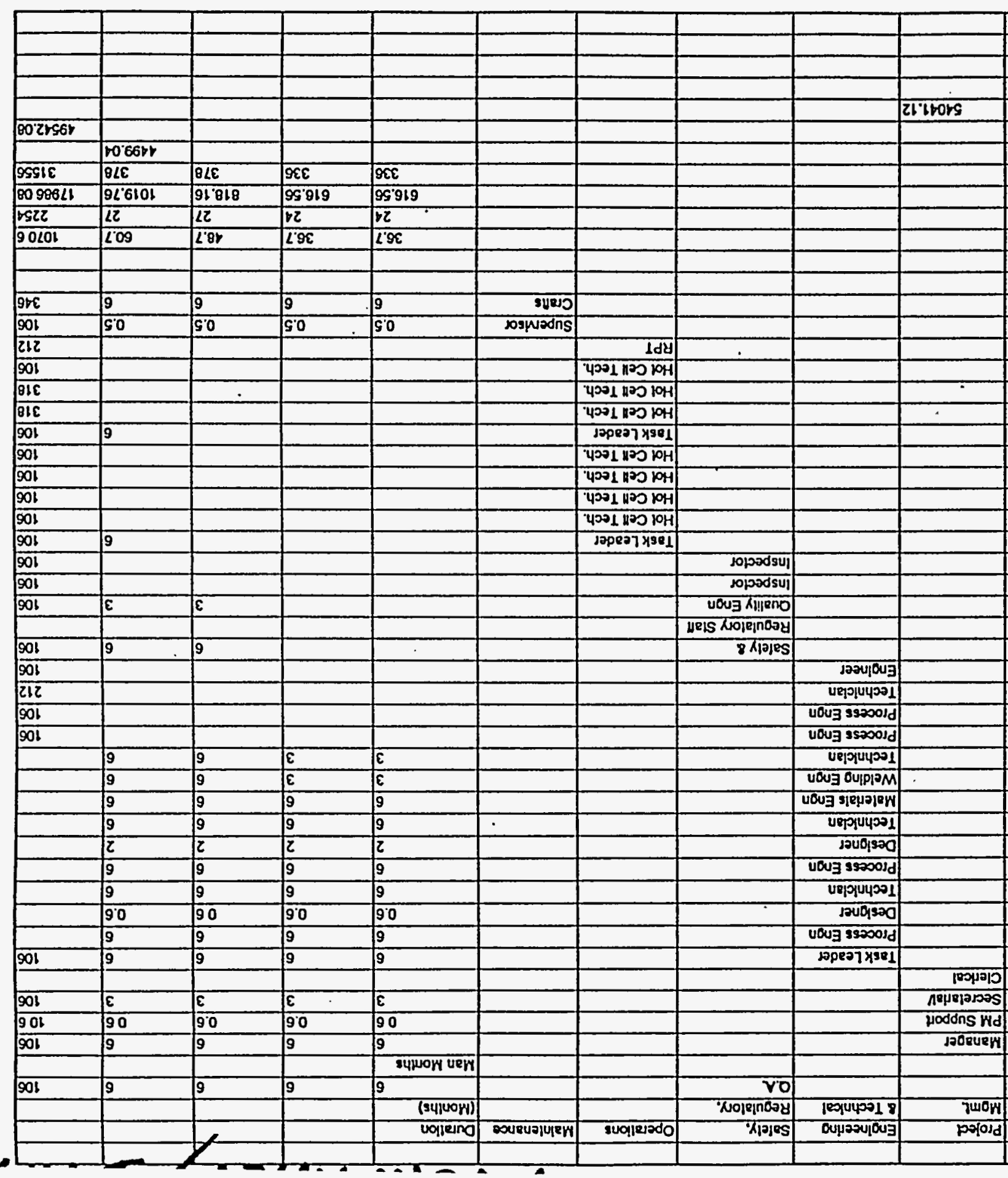

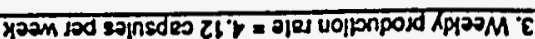

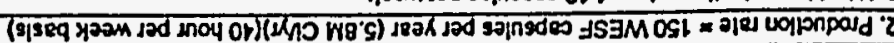

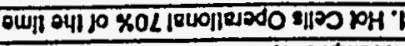

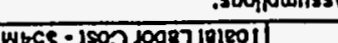

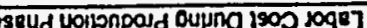
Ho|le) 3 sow

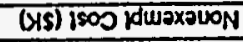

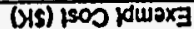

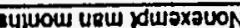

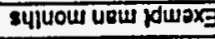
S7Y101

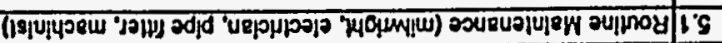

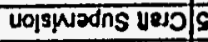

Ouाpuph गएलM L'Y 12noway Qg 96

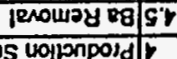

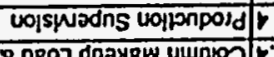

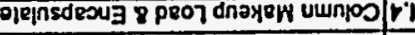

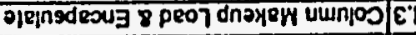

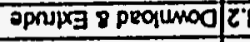
oprupg 8 pequino it volistivadns volponposd uopradsui Eद

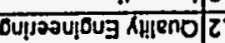

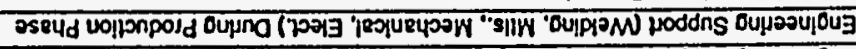

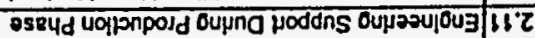

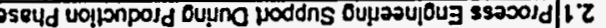

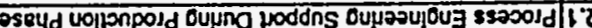

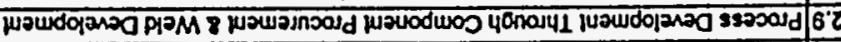

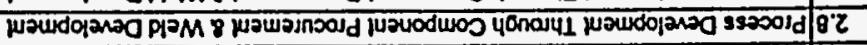

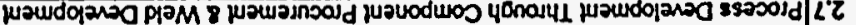

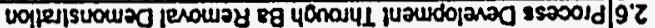

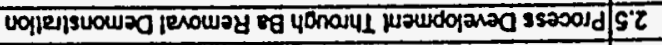

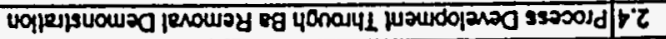

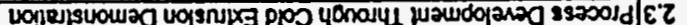

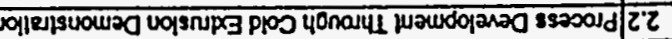

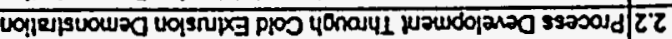

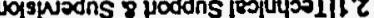

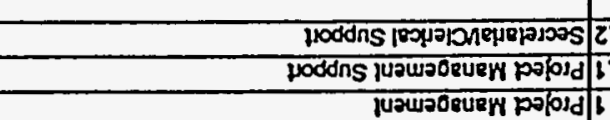

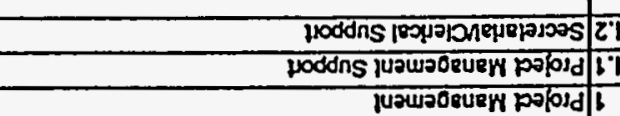

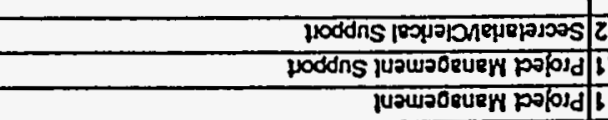

गणन pose 


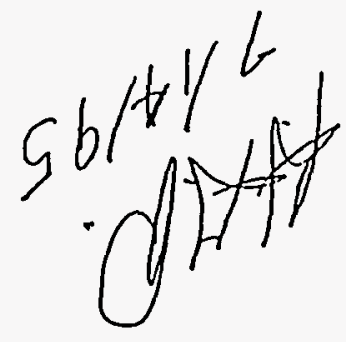

- จรдtดท甘

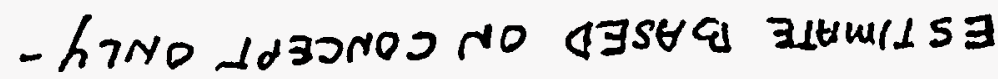

$$
\varepsilon \varepsilon 1_{\$} \cong 25 \mathrm{~S} / 2 / \mathrm{W} 89_{5}
$$

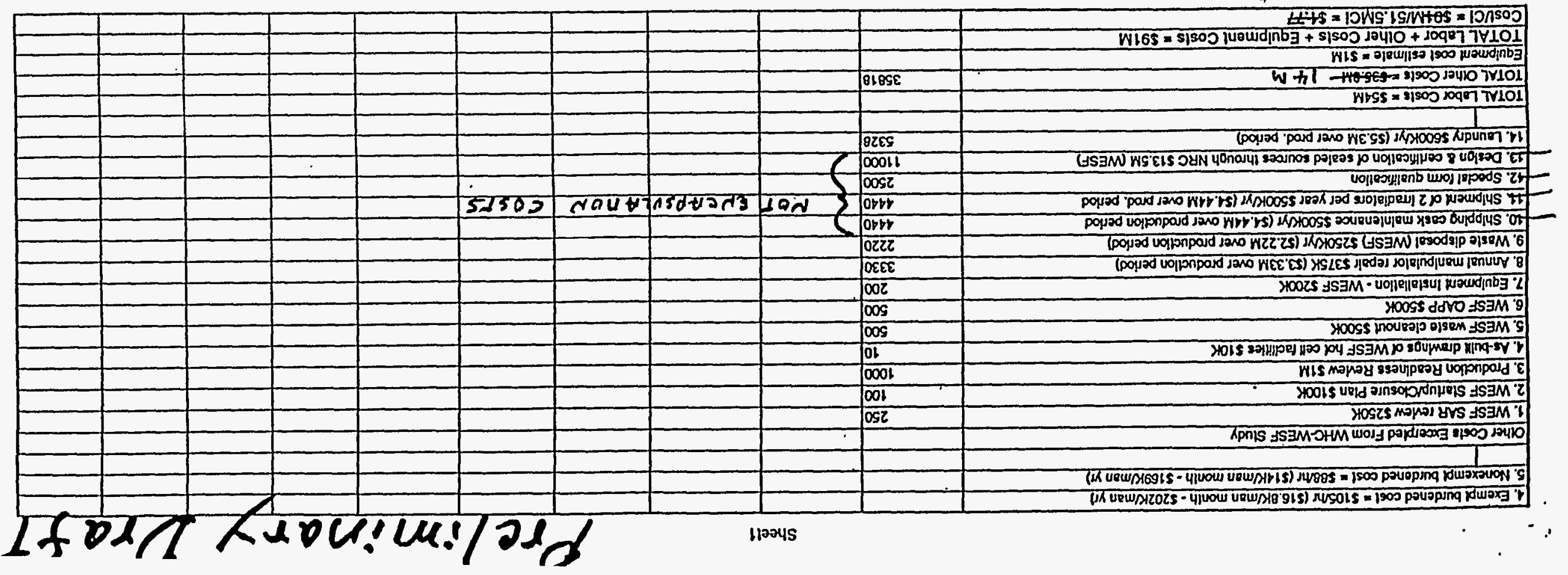


APPENDIX B

SAVANNAH RIVER CS-137 RECOVERY -- COSTS AND SCHEDULES

High-spot costs and schedules from the two main options and variants are presented below.

A. Recover the Cs-137 from the Precipitate Hydrolysis Aqueous (PHA) stream Capital Cost:.

$\$ 20-30$ million. $\$ 30$ million assumes current standards for construction of the facility. $\$ 20$ million assumes innovative standards and construction methods, as might be allowed under a fixed price contract. The cost of this ion-exchange facility would be smaller than for an ion-exchange facility to decontaminated supernate (see option $B$ ) because:

1. The flowrate is lower $(400,000$ gallons of. PHA per year versus $6,000,000$ gallons of supernate), and

2. The PHA has a lower level of radiological risk than the supernate. The main radiological hazard in the PHA product is the Cs-137, whereas supernate contains plutonium and uranium. Therefore, supernate has a high dose from accidental release and potential criticality hazards that are not present in the PHA.

Operating costs versus current operating plan:

Immediate savings are small, related mainly to flexibility in the DWPF because salt and sludge processing are decoupled. A large savings near the end of DWPF's life because the number of canisters could be reduced. Estimated savings are in the neighborhood of $\$ 500$ million from being able to shut down DWPF early and $\$ 150$ milition in reduced cost for disposal of canisters in the repository.

ScheduTe:

Facility could be started 2-5 years from decision to go ahead. Some pilot scale work would be needed to show that contaminants in the PHA such as boric acid and organics don't interfere with ion exchange.

No impact on startup and operation of ITP. Small impact on Salt Cell. A pipeline would need to be installed in the salt cell to route PHA to its intended future destination.

Other considerations:

Development is needed to show that ion exchange will work on the PHA process and also to show that cesium can be eluted as CsCl.

\section{A.1 Se71 entire PHA to a private company}

Capital Cost: 
Small (\$2-4 million). Need to install a waste transfer line from the Salt Cell to the contractor's facility.

Operating costs versus current operating plan: Same as for option $A$.

Schedule:

Would depend on private company. This could be fast if an interested company could be found.

Other considerations:

Performing ion exchange on the PHA stream would be less attractive to a private company than encapsulation because the composition of the PHA wiTl change depending on waste composition and will be subject to upsets in the salt cell, etc. Also development work is needed on the ion exchange process, as noted above. It may be difficult to find a firm willing to do this work, or the firm may insist on quality specifications and/or liability for upsets that might be costly to SRS.

B. Replace ITP and the DWPF Sait Cell with an Ion Exchange Process.

\section{Capital Cost:}

$\$ 50-100$ mil1ion. $\$ 100$ mil1ion assumes current standards for construction of the facility. $\$ 50$ million assumes innovative standards and construction methods, as might be allowed under a fixed price contract. The facility is expensive because of the high volume of the stream (about 6 million gallons a year) and the safety aspects (supernate contains uranium and plutonium, which could cause large doses from accidental releases).

Operating Costs versus current operating plan:

A savings of \$10-15 million/year from not running the salt cell and not having to purchase sodium tetraphenylborate. Some costs would be incurred in operating the new facility, but it is assumed that these would be offset by the savings of not running ITP. In addition to the immediate yearly savings, there is a savings near the end of DWPF's life in that the number of canisters could be reduced. Estimated savings is $\$ 500$ million from being able to shut down DWPF early and $\$ 150$ million in reduced cost for disposal of canisters in the repository.

\section{ScheduTe:}

The facility would begin operation 5-10 years after decision is made to go ahead. Only a small amount of development is required, but the time scale is Tong because this would be a large, major facility with high risk. ITP would not be operated. New strategies would need to be developed for ensuring adequate salt space (e.g. store salt in tanks 48 and 49 , which are currently planned to ITP, store salt in sound type tanks).

Other Considerations: 
The ion exchange process is more inherently safe than the ITP and the Salt Cell because of the lack of flammable organics. This might generate additional cost savings and other favorable programmatic impacts as new regulations and DOE orders are promulgated.

\section{B.1 Limited runs of ITP--Ion Exchange in DWPF Salt Cell:}

\section{Capital Cost:}

\$25-50 million. Putting the ion exchange into the DWPF salt cell would probably reduce the cost versus a stand-alone facility, but no good cost estimates are available.

Operating Costs versus current operating plan:

A savings of \$5-10 million/year from not operating the Salt Cell. After ITP was shut down, the savings would increase to $\$ 10-15 \mathrm{million} /$ year. In addition, near the end of the DWPF's life there would be a savings in the neighborhood of $\$ 650$ million from early shutdown and reduced canisters.

Schedule:

The facility would begin operation 5-10 years after decision is made to go ahead. ITP would start on schedule and operate long enough to eliminate"salt bound" condition in the Tank Farm.

Other Considerations:

The ion exchange process is inherently safer than ITP and the Salt Cell because of the lack of flammable organics. However, with the B.l variant option some of the risks of ITP must still be accepted. 

APPENDIX C

AMERICAN MEDICAL ASSOCIATION REPORT ON IRRADIATION OF FOOD 
AMERICAN MEDICAL ASSOCLATION

REPORT OF THE COUNCIL ON SCIENTIFIC AFFAIRS

CSA $R=$ Tort $1-934$.

Subjer:

Irsadiation of Ecol

Preserted by:

Yank D. Coble. Jr., MD. Chair

Referted v:

Reference Comrrittee $E$

(Charles P. Sbocmaker, 3. Ch, Chair)

\section{EXECUTTVE SUMMARY}

The irridiation of food has become an issue of incerest to physicians and consumers. The process continues to be aceepted by the scientinic community and approved by government agencies for increasing applicatices in the food industry, yet misconceptions concerning its sat:? abound.

Treating foods with irradiation has a number of positive consequences. Irradiating foods is particularly eĩective in controlling foodborne microorganisms. Irradiaricn kills bacteria. yeass, mold. insects. and other parasites. making food safer. Exposure to garima irradiacion an reard the maturation. senescence, and sprouting of fresh E-rits and vegetables. increasing their stelf lives and dereasing postharvest losses. An effective measure to reduc: the incideace of foodbome illness and increase the availability and consumpcion of fresh fruits and vegetables, irsclistion produces nc toxic residues in food and maintains the nutritive and sensory qualities of treated foods.

The safety of food irradiation bas been systematieally and comprehensively evaluated more than has any cther food technology. Irradiation can be beneficial by adding to the armamentarium of techniques used to mainuin it:e piesent safe. wholesome. and convenient food supply.

In this refort the Council on Scientific Altairs oriters several recommendations that may help remove unnecessary impediments to the expanding use of this techrolcgy. Although it may be preferable to not require stesific mention of processing technologies on food labeling. food irradiacion by statute is a "fiod additive". and by federal stante all food additives 'must be listed on food labels. Continuzion of use of the intemational symbol for food imadiation will minimize consumer confuision.

Resolution 502, adopted st the 1992 Interim Meeing, direcied the A.MA Council on Scientific Affairs io smody the matrer of food inndiaion in terms of iss safery and efficiency in retarding the spoilage of food and in killing crganisms.

$$
\text { Brief History }
$$

Food ingredients have been legally imadiated in the U.S. since 1963 and allowed radiation dosages are the most. restrictive in the world. Imadiation of some icedruffs (e.g.. spices) is a viable aiternative to gas sterilizacion. Foods for NASA. sstronauls haye been and still are sterilized by irtadiacion. ${ }^{1.2}$ Food irradizcion has been approved for comrinercial use in 37 countries. and is used on spices. gịins. pouttoes: oniuns: garlic. detioned chickss meat: frozen seatiood. dried rish. termented pork sausages. apples, srawberries, rasngess. and pupaya.' Thirty-eight indusrial gamma irndiation iaciiices are in operstion in the U.S. and approximately 160 cperate worldwide. Mlany of these facilities are being used to sterilize nonfood commercial products (e.g., dișosable medical and pharmaceutical supplies).

An intemational Geseral Standard covering irradiated loods was adopted by the Codex Alimencarius Commission. a joint body of the World Heslth Organization (WHO) and the Fool and Agriculture Organization of the United Nations (FAO) represencing over i $\$ 0$ eouncries, in 1983." This sendard is based on the findings of the Joint Expert Commines on Food Imadiation (JECFI) convened by the FAO, WHO, and Intemational Atomic E.:ergy Azency (IAEA). ${ }^{3}$ Afier craluaring the daca available in 1969. 1976, and 1980. JECFI concluded thar "the irridiation of any food commodity up to an overall average dose of 10 kilogray causes no toxicological hazard." The WHO. FAO, LAEA. and the Internacional Trade Cencre furcher endorsed the safery of irradiaring food with up to 10 bilogray (KGy) of gamina rndiacion in late 1989. and the Incernational Consultative Group on Food Imsdiation, representing the WHO, FAO, and LAEA, issued undaced guidelines for the implementaion of food irsdiation ca a commercial scale in 1990.' After yet another cxtensive reviex of all crising data. WHO relensed the following updated policy satement on September 23, 1992:

"Irradiated food produced under esablished Good Manufacuring Pracices (GMP) is to be considered safe and nutritionally adequare because:

i) the process of iradiacion will not introduce changes in the compisition of the focd which. form a toxicological point of view. would impose an adverse efiect on buman tealth:

ii) the process of irsadiaticn will not introluce changes in the micretion of the food which would increase the microbivlogical risk to the consumer;

iii) the process of irsadiàtion will noit introduce nutrient losses in the somposition of the food which, from a nutritional point of view, would impose an adverse efreet on the nutritional sanus of individuals or populations. " :

The U.S. Food and Dirug Adrinistration (FDA) has studied the safery and efficacy of focd irsuliacion repentedly. The agency has approvel irsadiacion: several times in the last 30 years for use in preserving and decontaminating a variety of foods:

- 1963: Imadiation of wheat and whent flour to eliminate insest infestation (duse: 0.2 to 0.5 kGy).

- 1964: Imadiation of white potatoes to inhibit sproting (dose: 0.05 to 0.15 kGy). 
- 199j: Imadiation of spices and try regemble seasonings 10 eliminate bacieria and their spores and insecrs (dose: up to $10 \mathrm{kGy}$ ).

- :985: Iradiacion of dry and debyctsted enzyme preparacions to eliminate bacteria and their spores and insects (dose: vo to 10.kGy).

-1985: Imadiation of fresh pork to inactivate Trichinae (dose: 0.3 w 1.0 kGy).

-1986: Irradiation of fresh fruits and vegetables to delay maturation and eliminate insects (dose: up 101 kGy).

- 1986: $\quad$ Irrodiation of dry and deiydrated berbs, spices. seeds. teas. and regetable seasonings (dose: up to $30 \mathrm{kGy}$ ).

- 1990: Imadiacion of fresh and frozen uncooked poultry produces (dose: 1.5 to $3.0 \mathrm{kG}$ ). The USDA concurred with this approval decision in 1992.

Uncler provisions of the federal Food. Drug. and Cosmeries Asi. radiacion used in the processing of focd is. for regulatory purposes. classified as a food additive. Federal regulacions governing food additives reouire all food addivives 10 be listed on food labels. Is the United States. the label of an irndiated food is in compliance with these regulations when it carries the internacioan food irradiation logo and eicher "Trealed with Radiation" or "Treated by. Inodiacion."

In November 1985. A. Harold Lubin. MD of the AMA Deparment of Foods, Nutrition, and Personal Health, revified before the Subcomminee on Deparment Operavions. Resenrch and Foreign Agriculture of the House of Representatives Commitree on Agriculnere concerning the safery and effiency of irradiating food. Dr. Lubin sated that - Many years of intemational experience have demonsunied that foods inzdiated at levels of up to $10 \mathrm{kGy}$ are safe to ent." "Food irndiation leaves no residue in food," "Food irndiation produces no significant reduscion in the nutritional quality of facd." "Food irradiation is efifective, in killing the microorganisms that cause food snci:!nge." and "Food irsacliation may also be a viable alterasive... to pesisides.... These satements echoed previous written conmeats sent to the subeommitter is :uly i984. and March 1985. by James H. Sammons. MD. U:E= A.MA Executive Vice Prevident.

A.HA Policy 150.987 recommended ter: the FDA classify focd irsuliacion as a "process." rache: :-2s? 25 a "food acilicive." The intent of this tecomme: =a::on was to confirm the saity of the process of irradiating :avls. In addition, susth a chinge in classinication wouid e:i.ninate the need for the food indursy to apply for FDA aperovval separstely for esth icod spesies or clasis (e.g.. appies. Eapes. puuley. spices) desired to be processed using tsi technology. Unionunately. by subsequent foderal sisute such a chang: in clessit:esaor would require the istrodus::ion of new legisiation in Congras. A reiuted AM! $\div$ Polizy. 150.9:- encourages the FDA to incterse their effors to ensure the safery of the U.S. food supply.

The Process of Foor Iradiacion

Food is passed through a radiacion field created by a rack of sainless reel rods containing cobalt- 60 and emiring gamma rays (wavelength $10^{-10}$ to $10^{-1} \mathrm{~m}$ ). Moverment at a controlled speed allows a nixed dose of radiation to be absorbed by the food. The faod itself or its packaging never come into direct contaet with the mdiation source.

Irradiacing plants are beavily shielded and automated to prevent human exposure to radiation. ${ }^{18.11}$ Thiee consecutive etrors are reguired for exposure to oceur. but only one step is required to shut down the radiation source. Furthermore, it is impossible for a "meltdown" to oceur in a gamma irradiator. The source of gamma radiation dices not produce neutons. the subatomic particles which can make substances radioactive; theretore, no nuclear "chain resction" can occur, no radioactivity can be released into the enyironment in the presence of proper shielding, and neither the walls of the irradiation room. the machinery inside the $500 \mathrm{~m}$. nor the products being irradiated can become radioactive. After dismanding. a fool imadiating facility is safe ior other business use without any residual radiation haiard to the new occupants or the general public.

Irradiacion of food does not create mdioactive particles within food or its packaging. ${ }^{\text {211 }}$. The isridiacion of food with $10 \mathrm{kGy}$ ieduces less than one becqueel of radicactivity per $1000 \mathrm{~kg}$ of food insuliated $\left(3.7 \times 10^{\circ 0} \mathrm{Ci}\right.$ per $1000 \mathrm{~kg}$ ); this amount of induced radioactivity is less than $0.0005 \%$ of the leyel of background radiacion nanurally preseat in food. ${ }^{\text {is }}$

\section{Imadiacios and Foxlbome Disease}

Foodborne diseases pose a widesoread threar to human bealth and are an imporant cause of teduced economic productivity. According to the Centers for Disesse Control and Preveacion (CDC). foouborne disease caused by pathogenic bacteria such as Salmonella and Campvlobacter. and by parsites such as Irichinae (pork) and dniskasis (fish) claim an eximated 7000 lives annually in the L.S. and cause 24 to $\$ 1$ million cases of diarrheal disense." The economic losses assavinted with this morbidity and moraity are estimatec' by the FDA to exesed 5 billion dollars annually. Irradiaticn of jood kills bacteria. Food can be exposed to varying tosages of radiation depeading on the publue health objective. Stesilization of all nonviml mictoorannisms ("radapperization") usually requires radiacion šosages $>10$ $x G y$ and is limited to dry and dehydrated herbs. spices. teas. and vege:ible seasonings that are unlikely to camprise more than a tin: fracjon of the diet. Destuction oi a subsantial fraction ci bacteria present ("radurizacion") is somparable to hea: pasteurizacion in effiectiveness and requires less radiation. For exampie, 1.5 to 3.0 kGy kill kenwes $99.5 \%$ to 99.995 of Sajmonella. Pseudomonas Achremobacter. and Lacrabacillus organisms on poultry carcasses. ${ }^{17.14}$ Trestmeni of refrigerated fresh fist: with $0.75102 .5 \mathrm{kGy}$ effecejve!t eliminates the primary spoils ge and pathogenic

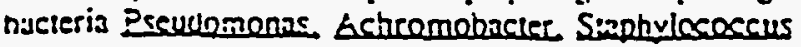

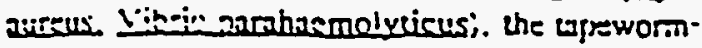


Dipbyllutosthoum baum, and the aemarodes Clohocehis sinensis and Daisakis marinii." Lower doses ( 1 l kGy) are ciffective as in inacivating parasites (including Trichinella. spialis in pork). killing insects. and inhibiting the sprouting, ripening. senexcence. and post-harver growrh of îuils and vegetables ("radicidation").

The typieal marimum radiation dosage, 3 kGy, way be insufficient to eliminate all contaminating Clestridium beoulinum spores if any are present. Eyen at this tow dose, inadiation is as effective as pasteurization in eliminating the risk of booulism. ${ }^{22=}$

Food irsadiacion cannot prevent contanination peseirsadiation, because irsadiation has no residual stīeos on food. In addition, irradiacion cannoc eliminate ric.obial woxins that have afready been formed in a foodrar $\bar{*}$. and should nor be viewed as a means of "correcting" iter poor managemeist practices.

Concerns have ren raised that because irradiation reduces the numbers of viable micoorganisms that cause visible spoilage (discoloration. rot, and odor), it may masti the odors or discoloration $t$ bat signal consumers to avoid food items that contain bacterial toxins. In fact. at coseges needed to virnully eliminate yegecrive pachogesic bacteria, sufficient numbers of spoilage bacteria survive to successitlly outcompere (suppress) any surviving pathogens that could generate toxins." In addition, irzadiacicn of food does not concenl spoilage that has already occurted. In addition. inadiacion does not increase the viruleace of pathogenic organisms that might survive the preess; yirulence ofien is reduced. Microorganisms have deyer been found to develop resistance to gamma irradiaticn. $=0$

\section{Irradiacion and the Food Supply}

The FAO has esimaied that worldwide about $25 \%$ of all foud prociuction is lost posi-harvest to insects. tacteria. molds. premanure germination. and rodents. The use of irsciation alone as a preservation technique will nor solve all the problems of portharves food losses. but it can play an imporant roie in curting losses and reducing the dejendence on chemical percicides.

High fock losses from infesation, contaminaticn. and scoilage: mounding consens over foodbome disenses: and growing international unde in food produces that miss meat stifi imper standards of quality and quaranivine are all areas in which food irradiation has demonstrated pracical beneño when inteznted within an eviablished system for the safe handling and distrioution of food.

There is to scientific evidence to indicate any health hazard is associated with the inadiacion of food conuining perticide residues or additives. The FDA has calculated that a dose of 1 kGy. which is typieal of the anount of radiation to which foods possibly containing persicides (inuits. yesecabier. and grains) are exposed. will generate about I grom or pesticice residue derivacives per 3000 metric tons of food irradiated $(0.033 \mathrm{pph}$ or $0.000033 \mathrm{ppr}$. Issuming the tod pescicide residue coneanirauon of the food averages 1 perm). The FDA charseterized this amcuni of addicional health bazard 25 "vinually nil" an!l contiluted tha: "the potential toxicity of ach radiolytic product from 2 pesticide chemical residue i foods that are irndized would be pegligible" 20d that "suc perticide residues do oot pose a hazard to bealtb. $\stackrel{ }{ }$ Similarly, irradiating food containing perticide residues anc food additives with :0 KGy would produce 2 conl mdiolyd production pool of 3 to 30 ppb (0.003 to 0.03 ppm). Therefore, the heslth bazard posed by the formation of radiolycic producis irom percicides and food addirives is extremely low.

All packaging materials for foods must be approved by the FDA, including those intended for use with food that is to irradiated. Packaging materials must remain stable and safi at radiation exposurs up to $10 \mathrm{kG}$. and must not suffet a loss in mechanical stength. increased in water or gas permesbility, $o r$ incrase in the exmactabilities of componen plascics. additives. Or adhesives. . $^{\text {.s }}$ A number of food packaging materials kave been radiation sterilized prior to coneacr with food ior many years:

Nitrocellulose-zoated cellophane

Glassine pape:

Wax-coated paperboard (diary product packeaging)

Polypropylene film writh or without plasticizers, ancioxidants. or sabilizers

Ethyleac-alkese-1-copolymer

Vinylidene Cl copolymer film ("Saran wrap")

Polystyrese. polyoleñn. polyechylene. and polyechylene terepinthalate films with or without plasticizers. ancioxichnts. stabilizers, vinylidene Cl copolymer film coatings. or polyeshylese coarings

Rubber $\mathrm{HCl}$ with or without plasticizers, antioxidants or szabilizers

Nylon 6

Nylon !!

Vinylidene $\mathrm{Cl}$ sopolymet-costed cellophane

Yezeable fasshment."

Irradintion and Foẹd liutriens Content and Organoleptic Qualities

The irradiacion of iccels increnses the temperature of the foods only slighely during processing. For example. an absortied radiajon cose of i0 kGy corresponds $t 02 n$ increase in temperature of $2.4^{\circ} \mathrm{C}$ in a food with the beat capacity of water. ${ }^{\infty}$ This feasure maximizes nurrient retention. Adverse changes in flavor, odcr, color, and texnure are minimized.

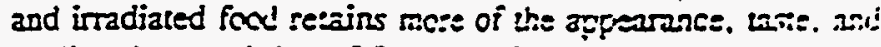
quality etazizesisies of fresh raw food.

Nutricional losse 5 :on irradiation are similar in magninude and nanure $w$ those resuling from oanning. ireezing. or drying with convesioaal mettals." Proteins, carbohydrates. and fatry acids are sabje during irradiation with up to $10 \mathrm{kGy}$. less than or sisi:i: to those ocsurring during cookins (10\% to ! $5 \%$ ) and an be minimized by exeluding oxygen from the eavironmen: (vasius packaging) and by miaimizirs tempersour: inereases during irradizsion.

Fewe: free roliea!s are genersted during irradiation thas during tonsing. Th: broiling. or treeze-drying. The

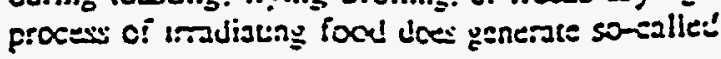


"radiolvic" products-glucose. formic acid, acealdebyde. benzese. formaldehyde. and carbon dioxide." The amounes produced ars minuseule, however, and bave been estimaled to toeal $30 \mathrm{ppm}$ or less when feod receives 1 xGy. The amount produced can be reduced further by freezing or vacuum urafping prior $w$ irradiscion. In addition. these chemicals are narurally present in human foods and in the bedy as incemediary mesabolices. and also are produced by thermal heacing of food." No subsances unique to irradiated fcods bave been idencified. ${ }^{\prime z}$

\section{The Idencinication of Irradiated Foods}

Several techrologies to detect whether a food item has been . iriadinted are under derelopment. Of those showing premise, four have been most thoroughly inverigated." Besause the mineral components of foods spontaneously emit light more intensely following irradiation, differential thermoluminescence is currently being eramined as method of qualizatively ideatifying irradiated foods. ${ }^{4, \pi}$. Unfortunately. thermoluminescence fades during storage. Electron spin resonance (ESR) spectroseopy can detect the small number of free radicals that become entrapped-within bones. seeds. shells, and mineral crystals during irradiation." The suength of the ESR signal is proportional to radiation exposure of skeleeal tissues: ESR spectroseopy is being invertigated as a means of eximating radiation dose administered to foods containing boaes and shells.

A technique that may be applicable to all food sources is the detection of the incteased fraction of hydrocarbons of chain lengeh $\geq 14$ present arier irradiation. ${ }^{\text {nx }}$ Howeyer. the sability of these compounds during storge is uninown. Altematively. irradiation of triglycerides yields yery small amounis of sable and detectable 2-alkylcyclobutanone derivatives. ${ }^{\star}$

Other methuts that have received some anention include atrempts to count organisms killed by irsdiation and efforts to detert irmdiation-induced fragmentation of native nuclear and mitochondrial DNA. Although promising, inexpensive, and relatively easy to perform. these toss will only be useful with raw foods.

No method of identifying irradiated foods has yet proven sutistactory. In part. this dilerama reflects the success of irndiacion: the process does not generate any unique or biologically relevant visuil, sensory. chemical. biochernical, or physical signatures.

\section{Adverse Eritesis Mistukenly Atributed to the Ingestion of Irradiaced Food}

There has been one report of increased polyploidy in malnourished children fed irradiated wheat in india." Unfortunately. these investigators failed to include positive or nezative controls in their inivestigations. This single refror has never been validirted. An independent invescigutive committee of the Govemment of India issued a repudiation of the claimed link berween irradiated whent and inceased polyploidy in 1976. concluding that the available data failect to demonsorate any muegenic potential of imsliated wheat." The origind report was reeramined in 1988 by an advisory commines to the Austrian Parliament, which also concluded that the inicial report was unreliable and had acc been conismed by any of the many subsequent invesigations." The failure of long-term (90 days) consumpicion of irsadiated wheat to affect DNA in rats in vive bas been reported recently."

\section{Conclusion}

Treating foods with irradiacion has a number of posigive consequeaces. ${ }^{0.45}$ Irradiating. foods is particularly effective in controlling focdborne microorganisms. Irndiation kells pachogenic and spoilage bacteria, yeasts, mold, and inseets and inactivates parasites, making food safer. Exposure to gamma irsadiacion can retard the manuration. serescence, and sprouting of tresh fruits and vegetables. making food more available. An efrective measure to reduce the incidence of foodborne illness. irradiation produces no toxic residues in food and maintains the nutritive and sensory qualities of treated foods.

The safery of food irradiation bas been systematically and compreheasively validaced. Iradiacion can be beseficial by adding to the armamentarium of techniques used to maintain the present safe, wholesome, and conyenient food sopply.

\section{RECOMMENDATIONS}

The Council on Scientific Affairs recommends that the following satements be adopted and that the remainder of this repor be filed:

1. That the AMA affirm food irrsdiation as a safe and efiecoive process that increase the safery of food when applied according to governing segulations.

2. That the AMA considers the value of focd irradiation to be diminished unjess it is incorporated into a comprehensive food safery progrum based on good manulacturing practices and proper food bandling. processing. storage," and preparstion techniques.

\section{That the AMA encourage the Food and Drug} Adminismaion and U.S. Deparment of Agriesiture to continue the requirement that all irraliated fruits, vegetables, meats, and seafood carry the international logo that bis become recogaized as indiezting that the food bas been subjected to gamma irradiation.

4. That the AMA affirm the principle that the demonscration of safery requires evidence of a reasonable certainty that no harm will result but does not require proof beyond any possible doubt (i.e., "zero" risk does not exist). 
1. - Espert Panel un Fuevd Safery and Nuvrition. Bieldiation Presecration uf Fuxds. Chicsgo:Institute of Fuxl Technulugiss: 1983.

2. Kurel $M$. The tuture of irsidiation applications un earh and in space. Exerl Technol 1989: 41(7):95-97.

3. Luaharanu P. Firoxl imradiation: national and internatiunal perspectives. In: Procedings. International Conference on Seafoxd Irradiation. Junen. 1992. Buca Ratun. FL:CRC Press: in nesss.

4. Codex Alimentarius Commission. Cuxter General Standard fuc Inadiatel Foxdis and Recommended incemational cuxic of Practice for the opeation of

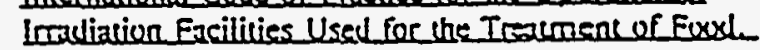
The Cuder Alimentarius. Vol. is Rume:Codex Alimentarius Cummission; 1984.

5. World Health Organization. Wholesemenear of - Irradialed Foxsh Bepor of a Joint FAO/IAEA/WHO Espert Commilles. Technical Repor Series No 659. Geneva:WHO; 1981.

6. Ansonymurs. International dixument un fixxd irradiation. In: Aeceptance Cuntrolur and Tradte in Irodiated Fexsh Procsedings of an Internativnal Sunference Geneva Swizerlanel $13-16$ Decembur 1988. Vienna:IAEA: 1989.

7. International Cunsultative Group on Food Imadiation. Coxdes of Govol inadiation Practice for Trestment of varives Fexul Cummoxities. Geneva:ICGFI: 1990.

8. Kaferstein FK. Food irradiation: the puxition of the Wurld Health Organization. Vienna:IAEA; 1992. $\because$

9. World Health Organization. Review of the Safav and Nurritional Adequacy of irradiated Foxpd. Gencya:WHO: 1993.

10. International Alumic Energy Agency. Safedy and Basliation_Prylection_Astects ur Canms and Electron Irradistiun Facilities. Vienna:IAEA: 1990.

11. MeKinnun RCi. Sitlety cunsiderutions in the derign of gamuna irradiation tacilities and the hundling of

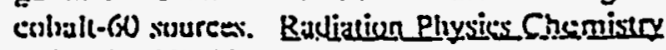
1988: 31:563-568.

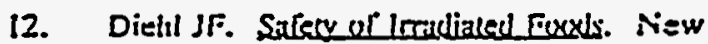
Yurk:Marcel Dekker; 1990.

13. UK Advisury Comnnittee un Nuvel and Irradiated Furds. Bepurtun the Sarely and Whuleomeness of Irradialed Funds. Lundun:HMSO; 1980.

14. Cuuncil for Agricultural Science and Technolugy.

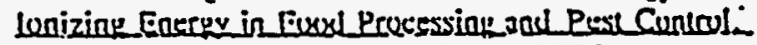
Repurde 102. Ames, lowa:CAST: 1986.

15. Miller $A$. Jensen P1:. Measurement of induced

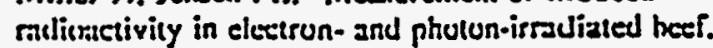
Intern J. Appl Rusliative Lisutupes 1987: 38:5177.512.
16. Archer DL. Eeunumic implicicions of frocthume

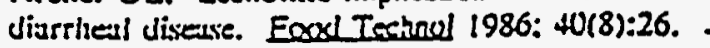
$\therefore$

17. Fuod Satery and Inspection Service. Irradiation of poultry producis. Exil Rer 1992: 57:19460-19469.

18. Urbain WM. Exxylaradiation. New Yurk:Academic Prexs: 1986.

19. Giddings GG. Radiation processing of lishery provluts. Exvel Techniul 1984; 38:61-65.

.2

20. Burditt $A X$. Furd irradiation as a quarantine treatment of fruis. EverL Tecinol 1982: 36:51-61.

21. Kaver $\wedge \wedge$. Polsotial applieations of iunizing radiation in post-ibarvest handling of fresh fruits and vegetables. Exxyl Technol 1986: 40:117-122.

22. Codex Alimentarius Cumnission. The

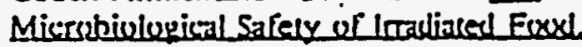
CX/EH/83/9. Ronie:C(xlex Alimentarius: Coununisuiun: 1983.

23. US fioxxl and bres Adlusinistration. Irradiation in the production. processing. and hasulting ol loved. Eed Beqf 1989: 55:18538-18544.

24. Heath Jl. Owens SL. Teseh S. Hannah KW. Errects of high-crergy e!estron irradiation of chicken meat on Salmuneila and zerchic plate count. Puelere Stii 1990; 69:150-156.

25. Gremblerg RA. Silliker JH. Nank WX. Schunidl Ct. Tuxin prexluction and urganulaptic breakdown in vucuum packaged fresh meats inoculated with Clustridiunn hotulinum. Eures. Researeh 1958: 23:65G61.

26. US lived and Dres Administration. Irradiation in the production. processing. and handling of foud. Eed Re! 1986: 51:13576-13399.

27. Killuran Js. Packzying irradizzed fixxd. In:

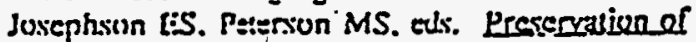
Eixud bv lunizing Ruslialion. Bexat Ratun. FL:CRC: Pras: 1983.

28. Clivaqui-OrTermans $N$. Foud packuging materiuls and radiation processing or foud: a hrief uves vicw. Ritlizlion Physie Chemistro 1989: 34:1005-1007.

29. U.S. Foud and Drug Adrninistration. Cudeer

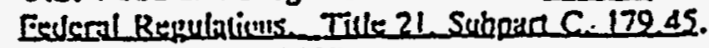
Washingtun:Cro: 1987.

30. Olszanna-Marhys Al. Radienctivily and foxsl prestervatiun. Nurritiva Revicues 1992: 50:162-165.

31. Taub 1^. Kuhbins F.M. Sirnic MG. Walker JE. Wierhicki 1:. l:Iticet of irradiation un mest proteins.

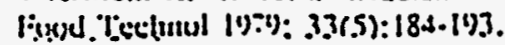


32. Jusephown ES. Thuntas MH. Calhuun Wx.

Nutritiunal zrpects of fixul irradiatiun: an uverview.

- LFuxxl Prox. Presery 1978: 2:299-313.

33. Adum S. Recent develupmen!s in radiutiun chemistry

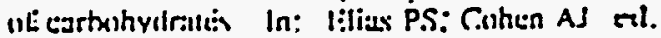

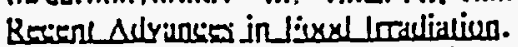
Aminterdam:Elixevier Bismedical Press; 1983.

34. FÄStB. Evaluation of the Heallh Astects of Cethin

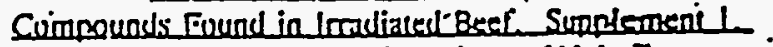
Eurther Turicological Cunsilerations of Volatile Compuivals. Sundement 2. Possihle Badiolvric Cumpounds. Bethesda:Life Science Researeh Office, Federation of Ameriean Societies for Experimental Bislugy: 1979.

35. Stevension MH. Progress in the identifieation of irradiated foords. Irends Fixul Sei Tech 1992: 3:257262.

36. Sandersun DCW, Slater C. Cairns KJ. Detection of intrdiated food lletrer|. Nature 1989; 340:23-24.

37. - Güksu-Ögelman HY, Regulla DF. Detetion of irradiated fixed |letter|. Noture 1988; 334:387.

31). Schreiher (iA. Schuizki C. Spiegelherg A. Halle $N$, Adam ST. Ammun J. Baumann P. Brockmann R, Banzigger U. Delincée H. Droz C. Bstendurfer S. Gemperle C. yon Grubuwski H-U. Känziy A. Krölls W. Matter L. Melschies M. Mildau G, Pfordt J. Plagu-Lixide A. Punker M. Rōnnefahr B. Ruge W. Steininer H. Vater N. Wilmers K. Bögl KW. Gas

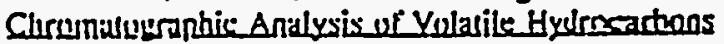

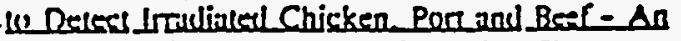
Intersumparisun Siudy. Berlin:Institut for Bundes gesundheitramies: 1993.

40. L.eTellier $M H$. Nawar WW. 2-Alkylcyeluhutanones from the rediulysis of triglycerides. Jjpids 1972: 7:75-76.

41. - Bheskarain C. Sadtasivan G. Eiffeels of feding irrudiated whest to mainusurished children. am I Clin Nitte 1975: 28:130-135.

42. Inturnutional Cunsultutive Group un liesxl Ieradiation.

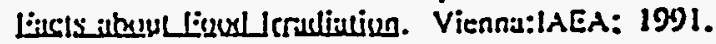

43. Macl'hee D. Hall W. An analysis of the salety or lixul irrulliation: yenetic effects. In: Usesar

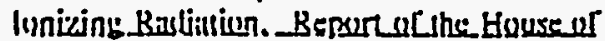

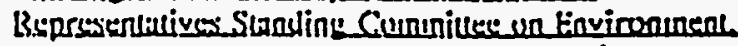
Recrestien and the Arls. Canberra: AGPS: 1988.

44. Maicer IP. Wenk-Sicfert 1. Schawalder HP. Zehnuler H. Sellitiler J. Cecll-ciycle and pluidy anslysis in bune marrow and liver cells of rats anter lung-lerm

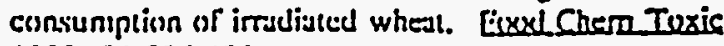
1993: 31:395-405.

45. Urhain WM. licxxl irrsuliatiun: the passt fitiy years

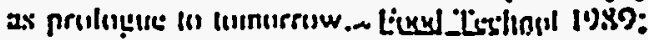
$41(7): 7677$ 

APPENDIX D

MARKETING STUDY FOR CS-137 IN FOOD IRRADIATION APPLICATIONS

FINAL REPORT 



\section{STUDY OF THE}

Fi) Wesiland Bulding

Bil, 5 Fing Sirred

i.st'li, Whationd

$-1213(1) 6\left(132 \cdot 68 B_{2} r_{1}\right.$

120n1621.9645
MARKET FOR

CESIUM-137 IN

FOOD IRRADIATION APPLICATIONS

FOR

Tri-Cities Industrial Development Council

Kennewick, WA

FINAL REPORT

- August 7, 1995 


\section{$\frac{\text { JOYCE }}{\underline{\text { \&ASSOCIATES }}}$}

CONTENTS:

I. Background . 1

II. Objectives . $\cdot 2$

III. Methodology 5

IV. Findings

- Segmenits 6

- Customer needs 23

- Competitive irradiating technologies 37

- Suppliers 44

- Current status of food irradiation 67

- Strategic partners $\quad 78$

- Market drivers 84

- Barriers/risks/liabilities 90

- Market size and forecast 101

$\begin{array}{lll}\text { V. Conclusions } & 108\end{array}$

VI. Recommendations 111

VII. Appendix

- Respondent list 113 


\section{BACKGROUND}

The Westinghouse Hanford Company is the recognized sole supplier of Cesium-137. under the US DOE's Isotope Production and Distribution Program. Derived from hazardous waste, Cs137 is pure enough to offer commercially and actually exists in inventory in encapsulated form. There is clear potential for building a sizable business in the Tri-Cities, with two benefits: the creation of jobs in the local community, and a reduction in the cost and liability of storing radioactive waste on site. TRIDEC, in partnership with WHC, would therefore like to acquire an understanding of the market for Cs-137.

Phase I of the study demonstrated the potential opportunity for Cs-137 in food irradiation. This report characterizes that opportunity. 
II. OBJECTIVES

The overall objectives are to characterize the demand for Cs-137 and to determine what Hanford would have to offer to compete. Specific objectives are:

1. Identify market segments and applications for the Cs-137 isotope.

- Food irradiation

- meat, poultry, seafood

-. fruit/vegetables

- spices

-. both foreign and domestic

2. Characterize the current and future needs of customers and potential customers, both technical and commercial, for example:

- Curies required per capsule, per shipment

- Purity/form isotope is supplied in (e.g., Cs-137 in ceramic or chloride form)

- Price

- After-sales support

- disposal

3. Identify competitors to an intended Hanford isotope supply business.

- Offshore suppliers (e.g., Russian for Cs-137)

- Competing radioactive isotope (e.g., Co-60 competing with Cs-137)

- Competing technologies

- Profile key competitors 
t. Determine the basic health of the industry.

- Supply side

- Demand side

5. Identify and profile organizations which could be strategic partners with WHC in the supply of Cs-137.

- Current competitors (e.g., Nordion, a supplier of C-60 food irradiation isotopes and systems, but a potential user of Cs137)

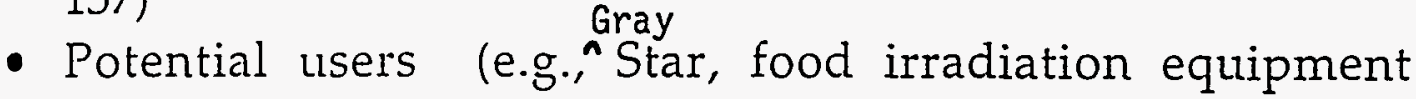
(start-up))

- Other companies that could partner with WHC to process and ship isotopes in a non-DOE environment

- Possible investors in a Tri-Cities-based business unit

6. Size the market Cs-137 with focus on areas of attractiveness to Hanford.

- Currently

- Over a 5- to 10-year time frame

- For North America primarily

- International markets, for applications in which the domestic market is too small to be attractive

7. Identify the drivers that will cause the market to grow and project market size 10 years out.

8. Identify barriers, risks, and liabilities associated with WHC's participation in that market.

- Risks, accidents, disposal, safety

- Any concerns about WHC as a supplier, Hanford as a site 
9. Identify, overall, the best opportunities for a Hanford isotope business.

- By market segment

- By application

- By isotope

- Short-term and longer-term 


\section{METHODOLOGY}

The first phase of the study consisted of preliminary interviews across all segments and applications.

This report describes the findings resulting from in depth interviews.

Respondents by Market Segment

Contract irradiation service companies

Irradiation system designers

Isotope suppliers

Competitive technologies

Meat industry

Poultry industry

Food service

Various food industries

Supermarket industry

Food brokers

Irradiation consultants

5

Academia, food scientists

6

State, federal, international officials

Miscellaneous

Total 
IV. FINDINGS

Existing domestic usage

Frozen poultry

- Limited use by health care facilities

- Distributed by Nation's Pride

- 22 Food Tech contracts to supply schools, nursing homes, hospitals in FL.

- Example: Flagler Hospital, St. Augustine, FL

$\bullet$.220-bed hospital

- Poultry costs extra 5 cents/lb

- Also served in cafeteria to staff, visitors, general public.

"We have a health care population significantly more at risk than the outside population. More elderly and people in a weakened condition. It (irradiation) helps to . reduce one of our risk factors." Jo Ellen Coleman, Director of Food Service, Flagler Hospital

- Clear rationale, justification

- no labelling required

- Niche likely to grow 


\section{JOYCE}

\section{Spices}

- Ingredients, herbs, industrial flavorings

- Not retailed as irradiated spices

Irradiation of spices "is making big inroads, especially with spices being used by food processors." Don Derr, Consultant

- Market dominated by Sterigenics

- $75 \%$ share of US irradiated spice market

- 25\%+ growth in irradiated spice revenue, 1993-95

- Tustin, CA plant operating 24 hours per day

- Only $6.5 \%$ of US spices currently irradiated 
$\frac{\text { J O Y C E }}{\text { \&ASSOCIATES }}$

Fruit and vegetable

- 5 to 10 supermarkets

- Exploratory basis

- Tough for justify dedicated irradiator due to seasonal markets

- Known distributors

- Caito Food, Indianapolis, distributing to Ohio stores

- Nation's Pride, Florida

- Known supermarkets:

- Carrot Top, Glenview, IL. Customers prefer irradiated strawberries

- Churchill's, Toledo, OH. Hawaiian papaya sale a big success.

- Chief Markets, OH. Participated in Hawaiian papaya experiment.

- Laurenzo's Supermarket, North Miami Beach, FL. Jan 1995, sold 1,000+ pints of strawberries in six days despite media circus effect.

- Wyndle's Foodland, Plant City, FL 
$\frac{\text { J O Y C E }}{\text { \&ASSOCIATES }}$

Potential domestic usage

Pork

- Approved since 1985

- No activity

- No commercial irradiation because:

- trichinosis killed at low cooking temperatures (137 degrees F)

-. few consumers like to eat rare pork

- - lower levels of radiation won't kill enough of other microorganisms. 
Fresh Poultry

- Approved

- Limited activity

- Industry denies safety problems

- Gun-shy, targeted by opponents

Example: Wyndle's Supermarket sold fresh poultry. Harassed by late-night phone calls by anti-irradiation groups.

"A couple of years ago we had a couple of member companies that were interested in doing trials and tests (with irradiation) but the group Food \& Water (anti-irradiation group) put a lot of pressure on them. They followed their trucks into the Vindicator plant in Florida and threatened the companies with a boycott. They were going to take out full page ads and basically told them they were going to ruin their brand name, so our members backed off (from pursuing irradiation)." Dr. Joseph Pocius, Director of Scientific and Regulatory Affairs, National Turkey Federation

- But major players interested

- All contract food service irradiators maintain relations, discussions, mini-studies with poultry industry

- Has sold well on very limited basis

- - Wyndle's sold 4,000 lbs last quarter 1993.

- 20 cents/lb more expensive than regular poultry. 
- Theoretical economic payback

"We estimate they'd get a payback in two years, based upon processing 150 to 200 million pounds each year, and being able to charge the consumer an extra 5 cents per pound. The actual irradiation costs would only be 2 cents per pound. We think this is a money-maker for the poultry business, by being able to sell a value-added type product." John Griessmayer, Executive VP, Applied Food Processors

- Current usage constrained by USDA packaging rule - Irradiation not allowed with conventional foambottom packaging

- Expensive laminated bottom package only 


\section{$\frac{\text { JOYCE }}{\text { JASSOCIATES }}$}

Meat Industry

- Especially ground beef

- Consensus: first major domestic market for irradiation

- Already losing market share

- Red meat petition with FDA backed by industry

- Meat industry has spent money on irradiation studies

Example: American Meat Institute, $\$ 500 \mathrm{~K}$ on 3-phase study

$\bullet$ Will it kill pathogens?

- Is taste/flavor acceptable?

- Will consumers buy it?

Example: New Mexico and Kansas beef councils funding Sandia $X$-ray irradiator development research 
- Small, aggressive entrepreneurs in meat industry

"The beef industry, unlike poultry, has a lot of entrepreneurs with small to middle-sized beef companies. It's easier for a small company to make that type of decision" to begin irradiating their products. "I know for a fact that there's strong interest with small, medium-sized companies out West." Dr. James Marsden, (formerly with American Meat Institute), Kansas State

- Unlike poultry, products sold without a brand name

- Internal company struggles pitting food scientists vs. marketers

- Big players maintain distance, but interested

- Food Tech discussions with states of Utah, Iowa

- Anecdotal activity re: interest by Iowa Beef Processors, Excel, Monfort 


\section{$\frac{\mathrm{J} O Y C E}{2 A S S O C I A T E S}$}

Seafood Industry

- Irradiation petition under FDA review

- Food quality historically a prime concern

- More aggressive than meat, poultry

- Most seafood eaten in restaurants

- avoid labeling problem

- chefs, foodservice business more receptive than supermarkets

- Shellfish industry concerned about losing market share

- Food Tech discussing possible irradiator in Louisiana 


\section{$\frac{\text { J O Y C E }}{\text { \&ASSOCIATES }}$}

Imported fruits and vegetables

- Clear economic rationale

- Especially quarantined products

- Hawaiian papaya growers exploring idea of irradiation site

- Most potential sales activity currently in this segment

- Gray*Star: Mexico, Spain

- J.L. Shepherd: Guatemala, Nicaragua

- Titan-Beta: Bolivia

- NRC reports inquiries from South America 


\section{JOYCE}

Government/Military

- Used by astronauts for meals in space since late 1960s

- Israeli forces in Persian Gulf War given irradiated rations. US troops envious of Israeli quality.

- Department of Defense no longer a technology and market driver for irradiation as in 1950-1980.

- shrinking budget

- too hot politically

"They (Dept. Defense) won't do anything until it becomes widely commercially available." James Fagan, Executive Director, Research \& Development Associates 
$\frac{\text { JOYCE }}{\text { \&ASSOCIATES }}$

International usage

- Most extensive use in:

- France

- Netherlands

- South Africa

- China

- Banned in some countries:

- Austria

- Germany

- New Zealand

-. Singapore

-. Sudan

- Sweden

- Switzerland

- 36 known countries with approved irradiation procedures:

North America

United States

Canada

Mexico

Cuba

\section{Asia}

India

Bangladesh

Thailand

South Korea

Japan

China

Pakistan 
$\frac{\text { J Y Y E }}{\text { \&ASSOCIATES }}$

Phillipines

Indonesia

Taiwan

Vietnam

Europe

United Kingdom

France

Denmark

Netherlands

Belgium

Russia

Norway

Hungary

Italy

former Yugoslavia

Finland

Croatia

Poland

Ukraine

South America

Chile

Argentina

Brazil

\section{Other}

South Africa

Israel.

Syrian Arab Republic

Australia 
Europe

- Most extensive use of food irradiation.

- Stagnant market

"If anything, it's (irradiation) backsliding. It's become very politicized by the European Commission." Food companies "have backed off because they can't move their irradiated products past their own borders. The whole thing has become politicized." Opposition by groups such as the Greens in Germany has led to "a state of paralysis in Europe" with regard to irradiation. 'Dr. George Giddings, Food Irradiation Specialist, Food \& Agriculture Organization, International Atomic Energy Agency

"Ever since Chernobyl, it's been impossible to discuss it politically." Tanya Roberts, Agricultural Economist, Economic Research Service, USDA 


\section{$\frac{\text { J O Y C E }}{\& A S S O C I A T E S}$}

Asia

- Rapidly growing market

Japan: Built commercial food irradiator in 1973 to treat potatoes used to supply fast-food restaurants. "It's going to be very big in Japan very soon." China is also a growth market: James Fagan, Executive Director, Research \& Development Associates 
India: "They're really coming on and building their own units."

China: "Irradiation is on a roll. They're doing a lot with industrial irradiation."

Dr. George Giddings, Food Irradiation Specialist, Food \& Agriculture Organization, International Atomic Energy Agency

- SteriGenics has recently built irradiators in Taiwan, Indonesia 
Central and South America

- Rapidly growing market

- NRC reports irradiation inquiries from this region

- Gray*Star and J.L. Shepherd sales activity here

- Key countries are:

"Mexico is really on the verge of building them for spices and tropical fruits. They're a huge fruit exporter to the US and traditional chemical fumigation is going out of favor, and the Mexicans are not happy with heat treatments."

Brazil: "For the same reasons as Mexico, to export fresh fruit and produce that may be under quarantine."

Chile: "They're a major shipper of off-season fruits to the US." ex. almost all winter table grapes in US come from Chile. Another plus is that Chile "already has experience with using it (irradiation) for medical sterilization."

Dr. George Giddings, Food Irradiation Specialist, Food \& Agriculture Organization, International Atomic Energy Agency

- South Africa

- Extensive sale of irradiated foods since làte 1970s

- First two years, 1978-79, 20 supermarkets sold irradiated products, including 13 tons of potatoes, 20 tons of mangoes, 20 tons of papayas, 7 tons of strawberries. 


\section{CUSTOMER NEEDS}

\section{Irradiator operator needs}

- Radiation source that doesn't raise safety concerns

- Within food industry

- Within contract irradiation industry

- General public

- Don't give anti-groups opportunity to shut down food irradiation in its infancy

- Safety

- Shielded access to source rack controls and mechanisms (ex. hydraulics, pneumatics) when it jams

- Remove operator decision-making from process

- Eliminate human access to irradiation chamber via lock-outs

- Operators too clever for own good; beat lockouts and die

- Appropriate alarms, back-up systems

- Gray*Star design seems inherently safe 


\section{$\frac{\text { J O Y C E }}{\text { \&ASSOCIATES }}$}

- Source that Provides Uniform Dosage

- Meet dosage ratios for selected foods

- ex. poultry, USDA minimum $=1.5$ kilograys

- ex. poultry, FDA maximum $=3.0$ kilograys

- Poultry dosage must be applied at 2:1 ratio

- Food Tech must re-ștack pallets to meet requirement

- Irradiator must satisfy federal regulations 
NRC

- want to reduce operator decision-making

- expensive process for approval of transportation cask

- survive one meter drop onto 6-inch steel spike

- survive exposure to 475 degrees $F$ for 30 minutes

- survive 30-foot drop onto hard surface

DOE

- seek solution to cesium encapsulation problems

- Gray*Star claims solutions:

- use dry shielding, avoid thermal cycling

- loosely packed cesium capsules

- smaller, flatter capsules

- horizontal storage

- bake capsule parts prior to assembly

FDA

- set ceiling on upper dosage for foods

USDA

- set floor on lower dosage for foods

- establish operation procedures, safety training

- monitor irradiator operations

- packaging rule has constrained irradiation of poultry 
Effect of Price on End Product Cost

- Food industries express this in cents/pound

- Method used by Chicago commodity markets

- Low-margin businesses, realize returns via high volumes

- Tightly managed. Meat industry payment terms = seven days

"We'll spend time looking at ways to save a hundredths of a cent per pound, anything from rooting out energy waste, or using cheaper cleaning supplies to how you handle and maintain coat frocks. One might justify building a new state-of-the-art facility that allows you to save $1 / 4$ to $1 / 2$ cent per pound." Stuart Polevoy, Chairman, Signature Foods

- Industries concerned about passing radiation costs along to consumer 
Likely Industry Response to Irradiation Costs

Attractive:

$1-2$ cents/lb meat/poultry, domestic fruit/veg

5 cents/lb imported fruit/veg

10 cents/lb shellfish, seafood

Feasible: $\quad 3-10$ cents $/ 1 b$ meat\& poultry

3-5 cents/lb domestic fruit \& veg

6-10 cents/lb imported fruit \& veg

10-20 cents/lb shellfish, seafood

Unattractive: $\quad 10+$ cents $/ 1 \mathrm{~b}$ meat \& poultry

$5+$ cents/lb domestic fruit \& veg

$10+$ cents $/ 1 b$ imported fruit \& veg

$20+$ cents $/ \mathrm{lb}$ shellfish, seafood 
Anecdotal Pricing Information:

- Nation's Pride, Applied Food Processors claim cost of irradiating poultry $=2$ cents $/ \mathrm{lb}$

- Current market price for contract irradiation of spices approximately 6 to 7 cents $/ \mathrm{lb}$.

"If you attach one of these irradiators to a poultry plant at cost of $\$ 6$ to $\$ 8$ million up front, and then you process 200 million lbs of poultry, that's an added cost of half a cent a pound. That's not unreasonable, if the public will buy it" (idea of irradiated foods). Charles Ellis, President, Ellis Poultry Processing, Inc. 
- Cost of Isotope Source

- Market indicates that pricing in range of $\$ 1 / \mathrm{ci}$ or less is needed for cesium-137

- Gray*Star's own economic analysis: cesium must be priced at near zero for raw material, and cost of encapsulation should be around $\$ 1 / \mathrm{Ci}$ instead of $\$ 7 / \mathrm{Ci}$.

- Analysis holds up well in real market.

- Current market price for cobalt ranges from $\$ 1.20$ to $\$ 1.80$ per curie.

- Because of increased and perceived risks of using Cs-137 there must be a material/substantial advantage to using Cs-137 over Co-60.

"It depends on how it's marketed. It has to be sold almost dirt cheap, because it's abundant in our reserves, though not all is encapsulated. If more cobalt supply comes on line because of new reactors being built by the Koreans, Argentinians and South Africans, then it would be very tough for cesium to get a piece of the action. Unless it's very cheap and they (Hanford) promise to take it back (once half-life is reached). The Canadians have marketed cobalt that way, and have been successful." Dr. Manuel LagunasSolar, Crocker Nuclear Laboratory, U-Cal Davis

"It's going to be tough for cesium. Cesium has to play catch-up ball with cobalt and use of e-beam." Don Derr, Consultant 
"My guess is that it's better to go with cobalt-60 for . building routine, typical units. But I understand that cesium would be cheaper in the long-run. I think once the idea of irradiation catches on and is accepted by the public, they (irradiation service providers) will use whatever proves to be the most economic, which is cesium. But for starters, they'll stay with cobalt because it's less controversial." Dr. Lyle Wong, Plant Industry Director, Hawaii Department of Agriculture

- Babcock \& Wilcox position: "We think it might be cost-effective to the government to give away cesium to avoid the cost of storing, monitoring and taking care of it." Ray Posey, Manager of Business Development, Nuclear Equipment Division, Babcock \& Wilcox 
Comparison of Irradiator Types

- On-line continuous and freestanding machines will be more economic than batch (Gray*Star) design at high throughputs.

-. e.g. $400 \mathrm{M} \mathrm{lb} / \mathrm{yr}$. of poultry

- Cross-over point (throughput at which batch becomes more economic) is materially influenced by the price charged per Ci of Cs-137 (as well as the price charged per $\mathrm{Ci}$ of $\mathrm{C0}-60$ )

- Batch machines compare most favorably to other designs at low throughput levels.

- For poultry applications in US*

-. packing plants of $52 \mathrm{M} \mathrm{lb} / \mathrm{yr}$. and up represent $60 \%$ of total output.

-. packing plants of $26 \mathrm{M} \mathrm{lb} / \mathrm{yr}$ and less represent only $15 \%$ of total output

- For papaya applications*

-. $50 \mathrm{M} \mathrm{lb} / \mathrm{yr}$ represents approximately $2 / 3$ of the annual Hawaiian output.

* Sample economic comparisons for poultry and papaya are shown on page 31a. 
Sample Economic Comparisons*

Application: Poultry

$\begin{array}{lccc}\text { Machine Type } & \begin{array}{c}\text { Typical } \\ \text { Thru-put } \\ \text { (Mlb/yr) }\end{array} & \begin{array}{c}\text { Capital } \\ \text { Cost } \\ \mathbf{( \$ M )}\end{array} & \begin{array}{c}\text { Annual } \\ \text { Operating } \\ \text { cost } \mathbf{( \$ M )}\end{array} \\ \text { On-line continuous } & 52 & 6.0 & .75 \\ \text { Batch } & 46 & 6.0 & .3\end{array}$

Application: Papaya or Grapefruit

$\begin{array}{lccc}\text { Machine Type } & \begin{array}{c}\text { Typical } \\ \text { Thru-put } \\ \text { (Mlb/yr) }\end{array} & \begin{array}{c}\text { Capital } \\ \text { Cost } \\ \mathbf{( \$ M )}\end{array} & \begin{array}{c}\text { Annual } \\ \text { Operating } \\ \text { cost (\$M) }\end{array} \\ \text { Freestanding } & 48 & 2.2 & .8 \\ \text { On-line Continuous } & 50 & 4.0 & .5 \\ \text { Batch } & 50 & 1.8 & .13\end{array}$

\footnotetext{
* Capital and Operating costs are as supplied by WHC, based on data supplied by Nordion, USDA \& Gray*Star.

* Two Gray*Star batch machines are required to reach output of $46 \mathrm{Mlb} / \mathrm{yr}$. for poultry.

*Batch machine costs assume Cs-137 available at $\$ .50 / \mathrm{Ci}$, as projected by WHC, under a cost avoidance program
} 
Multiple Designs for Different Markets

- Free Standing Plants

For contract service providers or food processors

Highest throughputs

Like 747, want irradiator running all the time

- Bulk Irradiators

For grains, walnuts, almonds, possibly spices

Very high volume, low labor costs

World's largest at Port of Odessa, Ukraine

Limited to products suitable for screw conveyors

- On-Line Continuous Irradiator at Processing Plant Theoretical only -- none in practice

Makes sense if 2-3 shifts, 300+ days annually

For selected high-volume foods

- ex. ground beef only at meat plant

- ex. chicken breasts only at poultry plant

- Off-Line Batch Irradiator at Processing Plant

Gray*Star concept uses cesium-137

Logical for low-volume plants, or seasonal foods

Makes sense if plant not operating 4,000+ hours

Why? Cesium depreciates more slowly than cobalt- 60 . 
Target Markets for Irradiator Types

Machine

Type

On-line
Gray*

Nordion Star

$x$

$X$

Freestanding $\quad X$

Bulk

Batch

$x$
Shepherd AFP

$x$

meat, poultry, spices

grains \& nuts

Seasonal fruits, vegetables \& Seafood. Lower throughput meat and poultry 
- Computer Controls \& Automation

- Allows for higher production rates

- Irradiator must be easy to use

- Reduce staffing size

- High-volume plants operating $250+$ days will want more automation

- Low-volume plants operating < 200 days will accept less automation

- Automatic barcode print-outs of radiation operations

- Easy Replenishment of Isotope Source

- Co-60 must be replaced 6 times more frequently than Cs-137.

... a nuisance and an added operating cost

- Co-60 replenishment takes place annually, with replacement of $20 \%$ of total $\mathrm{Ci}$.

-.. so that output never drops below around $80 \%$ of maximum

- Gray*Star machine design would not appear to permit the same replenishment strategy. 
- Return Radioactive Material at Half-life for Disposal

- - Gray*Star predicts secondary market for cesium irradiators will develop

Scenario: customer needs high dose for meats, poultry

...cesium depletes after 15 years, can no longer efficiently irradiate meat

... would then sell cesium irradiator to someone requiring lower dosages (ex. potatoes)

- - Scenario not as secure as Nordion take-back arrangement for cobalt- 60

- Additional problem w/ scenario: sale of Gray*Star units to high dose, high throughput markets (meat/poultry) less economically viable

- Gray*Star units more likely to sell into fruits and vegetables and low throughput meat and poultry 
- Location

Contract irradiators successful only if strategically located

- SteriGenics spice irradiation plant in CA

... CA major domestic source of garlic, onion, herbs

... Port of LA moves $60 \%$ of all spice imports

- Food Tech Services situated in FL to irradiate citrus

... citrus industry hasn't accepted irradiation

... too far away from other potential markets

- minor Gray*Star limitation -- might be difficult to site in locations with high water tables

- concerns about cesium's solubility in water

- Major industries want nearby irradiators

Poultry -- in southeast

Meat -- in Midwest \& West (Food Tech talking to Iowa, Utah)

Fruit \& Veg -- major coastal ports and growing regions Seafood -- Gulf of Mexico especially 
$\frac{\text { JOYCE }}{\text { \&ASSOCIATES }}$

COMPETITORS

Technology Overview

- Isotope-based irradiators

Cobalt-60

Cesium-137

- Machine-based irradiators

Electron-beam accelerators

$X$-ray (under development)

- Other technologies

Pulsed electrical fields

Pulsed light 
How They Work

Cobalt-60

- Non-radioactive Co-59 mined from ore deposits

- Co-59 assembled into rods, placed in nuclear reactor for 18-24 months

- Co-59 absorbs one neutron, becomes radioactive Co-60

- Gamma rays dislodge electrons from atoms and molecules, converts to ions.

- Interferes with cellular division

Cesium-137

- By-product of nuclear weapons, development, and commercial nuclear waste

- Most radioactive by-product in spent waste was reprocessed into cesium chloride powder by DOE until late 1970s

- Gamma rays dislodge electrons from atoms and molecules, converts to ions

- Interferes with cellular division 
$\frac{\text { J O Y C E }}{\underline{\text { \&ASSOCIATES }}}$

Electron-beam accelerators

- Stream of electrons generated, accelerated down long tube.

- At tube end, magnet bends electron beam, filters out selected electrons

- Results in uniform electron beam sweep over target

- Electrons dislodge other electrons in cells

- Interferes with cellular division

X-ray Irradiator

- Conventional: electrons slammed into metal plate (tungsten, stainless steel)

- Conventional: when electrons strike plate, energy converted into heat and X-rays.

- X-rays dislodge electrons from atoms and molecules, converts to ions

- Interferes with cellular division.

- Sandia: concentrate electrons into high voltage pulses (120 per second)

- Sandia: accelerate electrons across small length of diode, rather than long tube 


\section{Advantages}

Cobalt-60

- Constant radiation source for processing

- Decays into stable nickel after 175 years

- Non-soluble in water

- Excellent safety record

- Thorough penetration of food products

- Multiple market sources

- Foreign supply will continue to grow

Cesium-137

- Half-life of 30 years = depletion of $1.6 \% / y r$

- Constant radiation source for processing

- Multiple international sources (UK, France, Russia)

- Thorough penetration of food products

- Requires slightly less shielding than Co-60

- Gray*Star design eliminates need for water pool 


\section{J O Y C E \\ \&ASSOCIATES}

Electron-Beam Accelerators

- High throughput

- Radiation stops with machine is turned off

- Public perceives lesser safety risk

- Conveying systems simpler than Co-60

- Radiation can be focused/directed

$X$-ray Irradiators

- Public is familiar with X-ray technology

- High throughput and thorough penetration

- Radiation stops with machine is turned off

- Radiation can be focused/directed 
Disadvantages

Cobalt- 60

- Half-life of 5.25 years $=12.5 \%$ yearly depreciation of source

- Must be replenished on regular basis

- Lethal radiation source can't be turned off

- Requires slightly more shielding than cesium-137

- Public perceives safety risk

- Small US supply

- Needs water pool - pallet refrigeration a problem

- Requires more stringent safety systems than Cs-137

Cesium-137

- Doesn't decay to background radiation for approx. 1,000 years

- Public perceives high safety risk

- GA accident resulted significant financial losses for end-user

- Lethal radiation source can't be turned off

- Limited US supply

- Industry perceives problems with encapsulation

- Soluble in water

- Expensive to re-process waste into cesium chloride 
Electron-Beam Accelerators

- Electrons on atomic particles, not rays

- Therefore, shallow penetration (1-3 inches)

- Too shallow for most food products

- Operating costs fluctuate with price of electricity

- Machine could malfunction, create work stoppage

$X$-Ray Irradiators

- No commercially available products

- Energy conversion problem if formidable

- Machine could malfunction, create work stoppage 
J O Y C E

\&ASSOCIATES

SUPPLIERS

Isotope Source Suppliers

Cobalt-60:

Nordion International

Amersham

Argentine Federal Government

South Korean Government

Neutron Products (re-process in US)

Cesium-137:

Hanford

United Kingdom

France

Russia

Savannah River

Contract Food Irradiation Services

Isomedix, NJ

RTI, NJ

SteriGenics, CA

Food Tech Services, FL

New Horizon Technologies, WA (potentially) 


\section{$\frac{\text { JOYCE }}{\text { \&ASSOCIATES }}$}

Design of Food Irradiators

Nordion Int'l, Canada

Applied Food Processors, VA

J.L. Shepherd, CA

Alpha Omega Technologies, NJ

CCM Sulzer, France

Gray*Star, NJ

Thomson Tubes, France

CGR Mev, France

Titan-Beta, CA

Radiation Dynamics, NY

Ion Beam Applictns, Belgium

Sandia Labs, NM
Cobalt

Cobalt

Cobalt, potentially cesium

Cobalt, potentially $X$-rays

Cobalt

Cesium

E-beam

E-beam

E-beam

E-beam

E-beam

$X$-ray

Pulsed light and electric fields

Other Technologies

Pure Pulse Technologies, CA 
$\frac{\mathrm{J} O Y C E}{\& A S S O C I A T E S}$

\section{SUPPLIER PROFILE}

Company: $\quad$ Nordion International, Ltd.

(Owned by MDS Health. Group, Ltd.)

Location:

Kanata, Ontario, Canada

Business:

Manufacture and supply cobalt-60 sources

Design and install Co-60 irradiation

systems

Operating Sites: Canadian Irradiation Centre, Ville de Laval, Quebec (training \& demonstration)

Apparent strategies:

- Promote food irradiation internationally

- To target markets

- Avoid promotion of technology to general public

- Emphasize cobalt-60's safety record

- Offer varied irradiator designs

Strengths:

- Dominant cobalt-60 supplier

- Dominant irradiator designer

- Deep pockets; Nordion annual sales = $\$ 200 \mathrm{M}$

- Technical expertise

- $30+$ years experience

- Demonstration site

- Market development resources

- Positioned as leader in FAO, WHO, IAEA irradiation literature 
Weaknesses:

Other Issues:
- Argentina, South Korea, growing competitors in cobalt- 60 market

- Contract firms say Nordion designs from supplier perspective, not for end-users

- First dedicated multi-food irradiator (Food Tech Services) not living up to throughput claims

- Irradiator can't meet FDA/USDA dosage ratio

- Committed to cobalt-60

- No interest in cesium-137 for food market

- Aborted arrangement with Hanford for

Cs-137 in other applications

- DOE raised price of Cs-137, Nordion walked away with bad taste in mouth 
Nordion Product Offerings:

- Pallet Carrier

- Used by Food Tech Services

- Powered monorail system

- Highly automated

- Containers "dance" around source 8 times

- Bulk Irradiator

- For grains, feeds, enyzmes, nuts

- Have built one

- Lowest cost per lb (\$1 per ton)

- High throughput

-. Minimal staffing

- Tote Box

- labor-intensive handling

- Carrier

-• labor-intensive handling

- suspended from monorail systems

- Pallet Conveyor

- - automated version of tote box design 
$\frac{\text { JOY Y E }}{\text { \&ASSOCIATES }}$

SUPPLIER PROFILE

Company: Neutron Products

Location: $\quad$ Dickerson, MD

Business: $\quad$ Re-processing of cobalt- 60

Contract irradiation services (no food)

Apparent Strategies: - Purchase cobalt-60 from Argentina

- Re-process for commercial use

- Focus on medical and industrial

- Not interested in cesium-137

- Observe, but don't pursue, food market

Strengths:

- Only significant N. American Co-60 supplier besides Nordion

- In business since 1958

Weaknesses:

- Small company, 90 employees

- Irradiation of spices accounts for $<1 \% \mathrm{rev}$

Other Issues:

- Estimated total revenue $=\$ 10^{\circ} \mathrm{M}$

- Strongly believe Hanford shouldn't supply commercial cesium-137 sources 
$\frac{\text { J } O Y C E}{\& A S S O C I A T E S}$

\section{SUPPLIER PROFILE}

Company: $\quad$ Food Tech Services

Location: $\quad$ Plant City, Fl

Business: Contract food irradiation service

Provide food irradiation design service

Operating Sites: Mulberry, FL

Apparent Strategies:

- Design and build irradiators

- Aggressively promote merits of food irradiation

- Develop personal relationships in meat and poultry industries

- Close co-operation with key distributor (Nation's Pride)

- Backed away from target supermarkets

- Re-focused on institutional food service

- Talk with state officials re: tax breaks, state bonds to build irradiators

- Iowa, Utah for meat

- Louisiana for seafood, poultry, export/import of fruit \& veg

- Provide food irradiation studies to customers (ex. Monfort) 
Strengths:

Weaknesses:

Other Issues:
- Good progress with hospitals, nursing homes (20+ contracts) .

- Can do wide variety of foods

- Established contacts in many markets

- Fearless. Will challenge opponents

- Potentially high irradiator throughput

- Plant only operates commercially 40 hrs/wk

- Other operating time for studies, tests

- USDA packaging rule stymied fresh poultry effort

- Geographically remote

- Bought too much cobalt-60 upfront

- Purchased 3.3 million ci

- Could get by with 1 million ci

- Co-60 depreciates estimated $\$ 40 \mathrm{~K}$ to $\$ 60 \mathrm{~K}$ per month

- Talking with Hawaiian growers re: irradiation of papayas

- Partnering with New Horizon

Technologies on Port of Pasco irradiator 


\section{SUPPLIER PROFILE}

Company:

Location:

Business:

Operating Sites:
SteriGenics International, Inc.

Fremont, CA

Contract food irradiation services

Design own.plants

Tustin, CA (spices only)

Schaumburg, IL

Westerville, $\mathrm{OH}$

Fort Worth, TX

Corona, CA (medical only)

Point Perkasa, Indonesia

Taiwan

Apparent Strategies:

- Primary focus on medical industry

- Secondary focus on cosmetics, spices

- Target industrial ingredients market

- not labeled as irradiated

- Full-page ads in ingredient magazines for spice, seasoning irradiation services

- Position company to take advantage of methyl bromide, ethylene oxide phaseouts

- Emphasize benefits compared to fumigants

- no chemical residue

-. cold process doesn't affect spices' flavor, smell

- no need to remove moisture

-. thorough -- not just surface area

- Conduct consumer field studies to nudge market toward labeled spices

- $100 \%$ committed to cobalt-60 
Strengths:

- Strategically located

-. CA major domestic source of US spice

-. Port LA receives $60 \%$ spice imports

- Tustin, CA plant operating 24-hours per day

- Spice revenue growth $25 \%+1993-95$

- International experience

- Dominate spice market with $75 \%$ share

- $\$ 35 \mathrm{M}$ annual revenues (vast majority. medical)

Weaknesses:

- Stigma from GA cesium-137 accident

- Suffered significant financial losses from accident and subsequent lawsuit

- company claims lost $\$ 250 \mathrm{M}$

Other Issues:

- Might publicly comment against Cs-137 if DOE/NRC moves to make commercially available

- Spice revenue estimated \$700K in 1994 
SUPPLIER PROFILE

Company: Isomedix

Location:

Whippany, NJ

Business:

Contract food and medical irradiation service

Operating Sites: Morton Grove, IL

Spartanburg, SC

Whitby, Ontario

Northboro, MA

Groveport, $\mathrm{OH}$

Whippany, NJ

Sandy City, UT

El Paso, TX

Chester, NY

Apparent Strategies:

- Site irradiators on key geographic regions encompassing 300-mile radius

- Primary focus on medical industry

- Provide enhanced EtO treatment at 3 sites

- Negotiate long-term fixed price supply contracts for isotopes

- Deal with multiple isotope suppliers

- Amersham, Nordion, Neutron

Products

- $100 \%$ committed to cobalt- 60

- Seek FDA approval to irradiate red meat

- Building new plant in Libertyville, IL

(operational 1996) 
Strengths:

Weaknesses:

Other Issues:
- Largest contract irradiation company in US

- Largest installed base of irradiation sites

- Submitted end-user savvy red meat petition

- hired George Giddings

- especially packaging

- Industry rumor: scrambling to replace lost medical customers

- Not well-positioned in food segments

- Less aggressive than competitors in marketing food irradiation services

- $\$ 47 \mathrm{M}$ in 1994 sales

- Estimated \$250K from spice irradiation

- Spent \$4M on isotope replenishment in 1994

- 1,060 customers (mostly medical, cosmetics)

- Aggregate design capacity at plants equal to 37.5 million curies of cobalt- 60

- Irradiated trial shipment of Hawaii papayas 
JOYCE

\&ASSOCIATES

\section{SUPPLIER PROFILE}

Company: $\quad$ RTI

Location: $\quad$ Rockaway, NJ

Business: $\quad$ Contract Medical And Food Irradiation service

Operating Sites: $\quad$ Rockaway, NJ

Salem, NJ

Graham, NC

Apparent Strategies: - 100\% committed to cobalt-60

- Low-key marketing of spice irradiation "customers find us"

- No plans to pursue other food markets

- Re-opened Salem, NJ site in late 1994

Strengths:

- Survival of company under difficult circumstances

- Spice revenues growing 10\% in 1995 
Weaknesses:

Other Issues:
- Burdened with environmental clean-up of superfund site

- NJ Dept Environmental Protection filed liens on company property

- Have no banking credit relationships

- Entangled with civil suits vs. founder Dr. Martin Welt

- Cannot borrow money via conventional means

- Founder (no longer with company) was jailed for making false \& fraudulent claims to NRC

- Estimated 1994 Revenues From Spice irradiation $=\$ 50 \mathrm{~K}$

- Approximately 170 customers (medical \& cosmetics)

- $\$ 4.4$ million total sales in 1994

- Bought $\$ 590 \mathrm{~K}$ of cobalt-60 to re-open Salem plant in late 1994

- Scheduled to purchase $\$ 380 \mathrm{~K}$ of Co-60 in '95 
$\frac{\text { JOYCE }}{\text { \&ASSOCIATES }}$

SUPPLIER PROFILE

Company: New Horizon Technologies

Location: $\quad$ Richland, WA

Business: $\quad$ Start-Up Firm

Seek to build contract irradiator, provide irradiation service

Apparent Strategies: - Build Co-60 irradiator at Port of Pasco

- Benefit from previous activities associated with prior DOE Pasco proposal in mid$80 \mathrm{~s}$

- Primary target: fruit \& veg processors

- onions, potatoes

- cherries, apples

- Secondary target: seafood and meat

- surimi especially

- 5 meat plants in eastern WA

- Focus efforts east of Cascades (WA, OR, ID)

- Employ experienced Tri-Cities nuclear personnel

- Seek funding from bonds, growers, private parties

- Give equity stake to Food Tech Services (will design plant)

- Reject use of cesium-137 for now but consider in long-term goals 
Strengths:

- Managed to persuade Food Tech Services concept had merit

- Can learn from Food Tech's mistakes

- example: will outfit with 1 million curies, rather than 3.3 million

- Intelligent marketing plan

- Two founders have 30+ years experience with food irradiation on technical side

Weaknesses:

- No funding as of yet

- Previous Pasco irradiator never built

- Limited private sector business experience by founders 
SUPPLIER PROFILE

Company: $\quad$ Gray*Star

Location: $\quad$ Mount Arlington, NJ

Business: $\quad$ Start-Up Firm

Seek to design, build and sell irradiators

Apparent Strategies: - Solve cesium-137 encapsulation problem

- Design unit as both transportation cask and irradiator

- Wrap source around target

- Use special plate to allow source to get close to target

- Target international markets

- Establish strategic relationship with

Babcock \& Wilcox

- Assume cost of cesium-137 =\$1/ci (including encapsulation)

- Seek NRC approval as machine, not plant

Strengths:

- Simple, innovative design

- Apparent solution to encapsulation problem

- Apparent solution to shielding dilemna

- NRC might allow licensing of design as a machine, rather than plant site

- Intrinsically safe design for operators

- Received six (\$10K each) down payments from two prospective customers 
Weaknesses:

Weaknesses:

Irradiator Design:
- Success hinges on many big "ifs"

- Unresolved encapsulation process

- Will NRC license as machine?

- Cask approval process could cost

$\$ 500 \mathrm{~K}$ to $\$ 1 \mathrm{M}$. Who pays bill?

- Cesium a dirty word in industry

- Cesium lightning-rod for opponents

- Unsatisfactory answers on replenishment and half-life questions

- Batch concept too slow for big volume foods

-1/7 thru-put of Food Tech

- Promotional materials under-estimate obstacles ("Food irradiation has become politically correct")

- 2.8 million curies of Cs-137

- 64 capsules of 44 kilocuries each

$\bullet$ loosely packed

- stored horizontally

- capsule parts dehumidified before assembly

- 164-ton steel cask

- fitted into 3,600 tons concrete

- $8 \times 10$ feet, 12 feet tall

- hydraulic cylinders move walls

- estimated cost $=\$ 2.2 \mathrm{M}$

- use chamber door handles as keys 
JOYCE

\&ASSOCIATES

SUPPLIER PROFILE

Company: J.L. Shepherd

Location:

San Fernando, Ca

Business:

Mfr calibration, dosimetry irradiation equip Seek to design, build Co-60 food irradiators

Apparent Strategies: - Use dry shielding (lead)

- Design both freestanding plants and modular irradiation cells

- Design bulk irradiator (grains, liquids, wastewater)

- Buy Co-60 from multiple sources

- Russia, Idaho DOE, Amersham,

Argentina, South Korea

- Target Central, South American fruits/veg

- Hot-water bath users

- Fumigation users

Strengths:

- Savvy marketing plan

- Intelligent use of marketing reps in Asia, Central and South America

- Market pull -- customers seeking solutions

- Developing Co-60 irradiator for firm clients in Guatemala, Nicaragua

- Discussions underway for bulk irradiator In Middle East

- Familiar with isotopes, irradiation from other product lines 
Weaknesses:

Other Issues:
- Small company, 35 employees

- Have yet to actually sell \& install unit

- Previously bought Cs-137 from Oak Ridge

- Unhappy experience with Hanford

- failed attempt to buy Cs-137

- 12 months, no results

- $\$ 100 \mathrm{~K}$ spent on capsule drawings

- BUT, still open-minded

- would consider Hanford Cs-137 if $\$ 5 / c i$ 
Other Minor Suppliers

Alpha Omega Technologies, Parsippany, NJ

- Designing Co-60 and X-ray irradiators

- Owner (Dr. Martin Welt) served 6 months in prison, 198990

- False and fraudulent statements to NRC

- Had turned-off safety alarms

- Trying to sell irradiation simulators

- No apparent success

Titan-Beta, Dublin, CA

- Electron-beam accelerator $\mathrm{mfr}$

- Focused on medical industry

- Maintaining contacts on food industries

- No plans to pursue food irradiation business

Radiation Dynamics, Edgewood, NY

- Electron-beam accelerator $\mathrm{mfr}$

- Built two small experimental food irradiators in $60 \mathrm{~s}, 70 \mathrm{~s}$

- No plans to pursue food irradiation

Irradiation Industries, Gaithersburg, MD

- Electron-beam accelerator manufacturer

- Small amount of university experiment food irradiation

- No plans to pursue food irradiation market 
Electron Technologies Corp., Windsor, CT

- Electron-beam acclerator $\mathrm{mfr}$

- Discussions with grain companies in 70s

- No success, no plans to pursue again

Pure Pulse Technologies, San Diego, CA

- Start-up firm

- Owned by Maxwell Laboratories

- Two technologies:

- pulsed electrical fields

- recently approved by FDA

- no commercial users

- limited to pumped or piped liquids

- competes vs. pasteurization

- pulsed light

- seeking FDA approval

- penetration limited to 10 microns

- target market is packaging industry 
Other Irradiator Development Efforts

Sandia National Labs and Kansas State

- Developing Repetitive High Energy Pulse Power (RHEPP) $X$-ray irradiator

- Use diodes to convert electricity into concentrated pulses (120 per second)

- Boost power conversion from electrical source

- $\$ 250,000$ project

- Funding from Kansas and New Mexico Beef Councils, DOE, Food Safety Consortium

- Meat, poultry tests at K-State

- Beef industry likes idea of machine that can be turned off

- X-rays provide penetration comparable to Co-60 and Cs137

- 2 to 3 years from commercial development

- Project lacks potential manufacturer (licensee) 
$\frac{\text { J O Y C E }}{\text { \&ASSOCIATES }}$

\section{CURRENT STATUS OF FOOD IRRADIATION USAGE}

Food Irradiator Installed Base

Country

Argentina

Belgium

Brazil

Canada

Chile

China

Cuba

Finland

France

Hungary

Indonesia

Israel

Japan

South Korea

Netherlands

Norway

South Africa

Thailand

Taiwan

Ukraine

United States

former

Yugoslavia

22 Countries

$\begin{array}{cc}\text { Primary } & \text { Secondary } \\ 0 & 1 \\ 1 & 0 \\ 0 & 1 \\ 0 & 3 \\ 0 & 1 \\ 2 & \\ 0 & 1 \\ 0 & 1 \\ 7 & \end{array}$

1

0

0

1

1

1

0

1

0

1

1

2

0

19

32
Applications

Spices, cocoa powder

Spices, shrimp

Spices

Spices

Onions, potatoes

Rice, apples, potatoes

Potatoes, onions

Spices

Deboned poultry, fruit spices, cheese

Spices

Rice

Spices

Potatoes

Spices, shellfish, mushrooms

Spices, poultry, potatoes,onions Spices

Nuts, grains, potatoes, spices

Onions, fermented sausage

Spices, rice

0 Grains

16 Spices, poultry, strawberries

2 spices
51 food-related irradiators 


\section{$\frac{\text { JOYCE }}{\text { \& ASSOCIATES }}$}

Petitions to Irradiate More Foods

Petitions reviewed by FDA

- Seafood

- submitted by Alpha Omega Technologies

- technically complex

- moving slowly through. FDA review

"Seafood ranges from everything to frogs to shellfish to boned fish, plus you have fresh water and salt water." George Pauli, Director of Division of Product Policy, Food \& Drug Administration

- Red meat

- pushed by industry

- submitted by George Giddings for Isomedix

- moving fairly well through FDA review

- use conventional foam-bottom packaging

-. dosage of 4.5-7.0 kilograys -- means need more source to maintain throughput

-. industry pushing, unlike poultry

Petition submitted "largely because the meat industry wanted the approval. The situation with illness pathogens seems to be more acute than it was ten years ago. It's changed a lot thanks to the Jack-in-theBox episode in Seattle and followed by similar E. coli outbreaks elsewhere. It's put the spotlight on the ground beef industry particularly." Dr. George Giddings, Irradiation Specialist, Food \& Agriculture Organization, International Atomic Energy Agency 
Operational Irradiation Regulations by USDA

- Establish irradiation criteria for:

- Proper dosage amounts'

- Use and disposal of water

- Refrigeration and handling of products

- Dosimetry measurements

- Training and shielding requirements

- Alarms, exit doors, etc.

- Procedures for labelling

- Typically two years for USDA to issue regulation

- Hot political issues dealt with slowly

- Our estimate - not until after 1996 elections

"With something like radiation, unfortunately, it's driven more by politics that it is by science or the technology itself. If there weren't public ramifications to it, it's quite possible it could only take six months. For one thing, things (new regulations) don't generally happen in an election year if there's political issues involved or any chance of controversy." Dan Inglejohn, Branch Chief, Processed Product Inspection, USDA 


\section{J OYCE}

\section{Growing Interest with Supermarkets}

- Hawaii papaya experiment changing minds

- One container load of fruit

- 24 stores participated in experiment

- Since successful experiment, supermarkets representing 600 stores altogether interested in participating in the next Hawaiian shipment

- More difficult to boycott as more stores participate

"The momentum is starting to pick up tremendously. It's a highly competitive industry. Supermarkets don't want their competitors to sell a product they don't have. The opposition to food irradiation is starting to crumble, because as more and more people get involved it becomes much more difficult to boycott two dozen different stores." Jim Corrigan, Owner, Carrot Top Market

- Actual irradiated product on shelves changes debate dynamics

"Food irradiation as a safety issue is no longer a public concern with $85-90 \%$ of the people. Those $10-15 \%$ that get bent out of shape over it, there's nothing you can ever do about them. One of the things we've learned from Jim Corrigan (owner of Carrot Top) is that once the product is in the stores, the assumption by $90 \%$ of the people is that the product will be safe." Dr. Lyle Wong, Plant Industry Director, Hawaii Department of Agriculture 
- Good success with recent irradiated food sales

"We had two varieties and both sold well. They retailed at $\$ 1.49$ each. We made enough money on it that it was worthwhile, even though we put them on sale." Walt Churchill, Owner, Churchill Supermarkets

- But big players still sitting on fence

"Consumer acceptance is the biggest hurdle we're faced with, especially with the specialized labeling that's required." Gayle Prince, Director of Regulatory Compliance, Kroger Stores

Top management feels it's not the right time now, that the customers aren't ready for it. They're watching to see what the rest of the industry's going to do." Dr. Ata Baroudi, VP Quality Assurance, Von's Supermarkets 
Reversal of Bans on Irradiation

- New Jersey moratorium allowed to expire

- Maine repealed ban in early July, 1995.

- New York State ban expires in Sept. 95; renewal is unlikely

Growth expected in nursing home/hospital segment

- American Dietetic Assn releasing paper to members in October endorsing irradiation

- Key players in adding irradiation to hospital, nursing home menus

- Trade publication serving dietician industry ran recent cover story on use of irradiated foods in Florida hospitals, nursing homes

- Good way to incrementally increase market share

"The marketing secret is to get it accepted in an area where people really need it -- sick little children, the elderly, immune-compromised people like cancer and aids patients. I think it should be promoted as a way of saying this is a technology for providing safe food to certain segments of the population. I think once it's accepted by that segment, it will become generally accepted by other segments." Jackie Ferreira, Marketing Manager, SteriGenics 
Pending endorsements, education campaigns, studies

- American Dietetic Assn

- American Medical Association

- Studies have found people trust local physicians more than out-of-town experts

- Food Marketing Institute (supermarket group)

- compiling educational packet re: the benefits of food irradiation. Will send 1,600 member companies, which account for 221,000 supermarkets.

- White House Food Safety and Nutrition Conference - expected to issue report that strongly endorses use of food irradiation

- USDA Agent Extension Service

- producing hour-long documentary on food irradation

- to educate 10,000 agents on irradiation

- deal with suppliers, brokers, processors, consumers

- especially valuable in Midwest, rural areas

- Purdue University

- developing nine-minute continuous play videotape

- sold at cost to supermarkets

- runs in supermarket aisles to inform/educate shoppers

- proven very effective in simulated-buy tests 
- 1995 International Poultry Expo in Atlanta, Jan 18-20

- first time irradiation on poultry industry agenda - panel discussions

- unwilling to discuss at all a few years ago

- Wide variety of medical groups proposing irradiation

"What you see is more and more people talking about food irradiation that are outside the food industry -- the American Medical Association, the American Gastrointestinal Society -- they're saying, 'Maybe irradiation is the answer to our problems."' Dr. Jerry Wellbourn, Director of Technical Services, Silliker Laboratories

- Creative marketing tactics

- Nation's Pride stages Irradiated Dinners

- eating is believing

- include guest speakers

"I did one dinner at a huge chef's meeting that had 12,000 people attending in Orlando." Bill Hargraves, Mgr. Agricultural Products Business Development, Nation's Pride 
Market still in infancy, under development

- No trade organizations

- No spokesman for the industry

- Nobody wants to be first

"There's a lot of people (companies) who want to be a fast second, but nobody wants to be first. Everybody lives in fear of adverse consumer reactions, things like boycotts. For companies with global brands, it's very, very complicated." Michael Goldblatt, Consultant

- Change in USDA attitude regarding food safety

"I see growing concern about the problem of food safety caused by large dramatic outbreaks that have caught the public's attention. The USDA had been doing a snow job for years by saying we had the world's safest food supply in the world. Now there's been a major shift in the USDA and they're acknowledging the problem. That helps. I also see growing acceptance in the medical community that it's a useful and valuable tool." .Dr. Rob Tauxe, Chief of Foodborne \& Diarrheal Diseases Branch, Center for Disease Control and Prevention 
- Potential buyers reluctant, but interest grows

"I have seen more movement in the last year in terms of the volume of food that's irradiated, the government pushing it, and the increase in public perceptions than in the last 25 years combined." James Fagan, Executive Director, Research \& Development Associates

"I know there's an awful lot of interest in it, but you don't hear an awful lot about it for the simple reason that a manufacturer or producer is sensitive to public feelings about it. No one's sure that irradiation is going to enhance their product in the market, so they don't want to have their product associated with it." Charles Ellis, President, Ellis Poultry Processing, Inc.

"Just about every food company that I know has considered irradiation, primarily because it's an excellent technology. But are any food companies seriously investing in it? I'm afraid the answer is no. They're trying to distance themselves as much as possible from the name 'irradiation'." Dr. Manuel Lagunas-Solar, Crocker Nuclear Laboratory, University. California at Davis 
- Growing actual usage within last year

- SteriGenics built new plant in Corona, CA; shifted 24-hour per day spice production to Tustin, CA - Isomedix new IL irradiator opens in 1996

- RTI re-opened irradiation plant in NJ late 1994

- Food Tech Service operating commercially 40 hours per week; plus test studies, etc.

- Many possibilities for new plants in works

- Food Tech talking with Lousiana, Iowa, Utah

- Hawaiian papaya growers want plant on island

- Gray*Star has six down payments from two customers

- - J.L. Shepherd designing two units for Central America, one potentially for Middle East

- New Horizon Technologies seek to site plant in Pasco 


\section{$\frac{\mathrm{J} O Y C E}{\& A S S O C I A T E S}$}

\section{STRATEGIC PARTNERS}

\section{Current Partners}

- Gray*Star

- irradiator designer/installer

- only Cs-137 pioneer/supporter

$\bullet$ Won't be easy

"It's going to be tough for cesium. GrayStar is interested in using dry storage cesium. I think they can get it cheap from the DOE. But the DOE is going to have to design a different type of storage capsule before it'll take off. The advantage is cesium has a longer halflife and a gives off a little more energy." Don Derr, Consultant

- Design not suited for big meat, poultry markets

"I'm not at all convinced the GrayStar design is going to take off. It's a batch type irradiator. I'm not sure they can get the needed throughput to serve the food industry." Don Derr, Consultant

- Have received six down payments of $\$ 10,000$ each

- One from Spain, five from Corporative Fruitico (Mexico) 
- Babcock \& Wilcox

- Genuine interest

"We find this an intriguing device in an emerging market. We see it as a genuine business opportunity. That's the basis of our interest in the product." Ray Posey, Manager of Business Development, Babcock \& Wilcox

- design/construction of shipping cask/irradiator

- privatized encapsulation of isotope sources

- credibility in nuclear industry

- limited liability company at INEL

- equity partner of operating company at Rocky Flats

- producing videotape to explain Gray*Star design

- hesitant to dig deep into their pockets

"We're reluctant to be a major funder. We do see lots of obstacles between where the project stands today and the point of being a successful product generating business. If we cannot find a way to have an economical source of cesium, there will never be a Gray*Star design." Ray Posey, Manager of Business Development, Babcock \& Wilcox 
- Concerned about cost of licensing shipping cask

"When we want to, we can scare ourselves and say it's (cost of licensing as a cask) well into the six figures, up to $\$ 1$ million to do the licensing. That could happen. We can imagine at least deep into six figures. A lot depends on the viewpoint of the NRC." Ray Posey, Manager of Business Development, Babcock \& Wilcox 


\section{$\frac{J O Y C E}{\text { J } O S S O C I A T E S}$}

Potential Partners

- Western Industries

- major quarantine fumigation company

- would be end-user

- located in New Jersey, near commercial firms

- familiar with Gray*Star, Isomedix, Alpha Omega, RTI

- company familiar with technology

"We're very pro-irradiation. Our company's been looking at it since the early 1980s as a possible means of diversification." Barbara Hunter, Marketing Director, Western Industries

-. Likes Gray*Star design

"I think it's a very innovative approach to solving some of the problems (associated with commercial irradiation). One Gray*Star advantage is you can hard program to give the same dosage all the time. And it's small enough that it can be dedicated to do one commodity. (And) "the Gray*Star system is selfcontained. There's not a lot of extraneous things that make it cumbersome to run an irradiator." Barbara Hunter, Marketing Director, Western Industries 
- J.L. Shepherd

- bad previous experience with Hanford

- door is still open

-. still interested in cesium

- currently designing cobalt-60 irradiators for customers in Guatemala, Nicaragua

- Isotope Product Laboratories

-. role in solving encapsulation problem

- supply isotope sources

- rocky relations with Hanford previously

-• but still interested

"We'd like to play a role in configuring the sources for them. The only way it could happen is to allow us to do it on-site at Hanford. Let us or Babcock \& Wilcox lease $a$ lab and work on the problem of using large level sources, putting large quantities of cesium in capsules." Dr. Gary Strathum, Isotope Product Laboratories 
Potential Partners (after cesium-137 accepted)

- Nordion

- possibly

- but very committed to cobalt-60

- annoyed by Hanford using fine print in contract to change price of its Cs-137 for medical use

- FMC Corp.

- supply steam/heat sterilization systems for food industry

- part of food irradiation study group

"We follow it (irradiation) from a distance, and we've given it some cursory looks in the past. We basically look at it as a potentially new technology, so we belong to the irradiation work group to keep tabs on the technology" Terry Heyliger, Thermal Processing Manager, FMC Corp.

- Food Technology Services

- most aggressive player in industry

- wary of Cs-137 political baggage

-. open to Cs-137 if Gray*Ban on chemical fumigants 


\section{DRIVERS}

Ban on chemical fumigants

- Methyl bromide

- most commonly used in commodity treatments for quarantined products to kill insects (fruit flies, coddling moth).

- due to CFCs, banned in 2001 in developed countries

-• banned in 2006 elsewhere

- Ethylene oxide

- used primarily to kill insects/bacteria in spices

$\cdots$ already banned in Europe

- tightened restrictions on US usage

- Highly unlikely new chemical fumigants will be developed

- food treatment applications account for only $15 \%$ of methyl bromide usage

- too small for chemical companies to justify research, investment in order to retain market share 
$\frac{J_{\text {O Y C E }}}{\text { \&ASSOCIATES }}$

Food safety concerns

- Main driver for health care facilities

- concerned about salmonella in poultry

- Centers for Disease Control attributes foodborne illness outbreaks to:

- $48 \%$ unknown

- 20\% seafood

- $15 \%$ meat

- $7 \%$ poultry

- $6 \%$ fruits \& vegetables

- $3 \%$ dairy products

- $1 \%$ eggs

- Various naturally occurring bacteria in shellfish, seafood

- Negligible concern with fruits, vegetables

- E.coli in ground beef driving much interest

- Occurs rarely, difficult to detect newer strains

- E. coli cells extremely lethal -- ten can kill 
- If E.coli detected, costly USDA product recall policy

-. November, 1994, Monfort lost $\$ 1$ million product from one day due to E.coli found in chub at supermarket

- recent ground beef recall at Kroger supermarket Tennessee (contaminated grinder suspected)

- FMI reports supermarket business drops $25 \%$ after a recall. Some never recover.

- But food safety hasn't generated irradiator sales

"There's a reluctance to stick their necks out and reluctance to take risks. They figure that they can ride out the storm of bad publicity related to negative publicity from an E. coli outbreak." Harry Mussman, President, Food Technology Service

"It's going to take something awful that happens -- like a major food poisoning outbreak -- that will cause public opinion to swing around. Charles Ellis, President, Ellis Poultry Processing, Inc. 
- New USDA regulations attempt to deal with problem

- start using microbial testing

- allow anti-microbial carcass rinses

- time-temperature controls

- standardized sanitation plans to control contaminants

-. push use of HACCP

- Fastfood restaurants respond with tighter cooking rules

- must cook ground beef to 155 degrees F

- somewhat vulnerable due to young work force

- McDonald's tightens contamination regs with four captive ground beef suppliers 
Quarantine on imported foods

- Especially fruits \& vegetables

- From Hawaii to US mainland

"Since the fruit fly quarantine, we've been looking at various ways to get our products to the mainland market. We'd heard about the good results with irradiated strawberries in Florida, so we decided to try this." "Our primary goal is to convince someone to build an irradiator in Hawaii. We're trying to build up support with state legislators to provide tax breaks and maybe assist with the funding for someone who wants to build it." Larry Nakahana, Mgr. of Plant Quarantine Branch, Hawaii Dept. of Agriculture

- From Central and South America to U.S.

"Specialty sales of strawberries, papayas ... importation of products that have to go through a quarantine. I think you'll see more of it used in import and export situations with quarantines." Dr. Jerry Wellbourn, Director of Technical Services, Silliker Laboratories

- Hot-water bath method damages the fruit too much

- Must be accepted by countries due to GATT

- Best potential for Gray*Star design 


\section{$\frac{\text { J O YCE }}{\text { \&ASSOCIATES }}$}

Shelf life $=$ competitive force in food retailing

- Early adopters in U.S. supermarkets view irradiation as way to make money

"We feel like it's an advantage for us. Once other stores see the success we're having, they'll get involved, too." Walt Churchill, Owner, Churchill Supermarkets

- Longer shelf-life

- Estimated that five-store Ohio chain would save $\$ 50,000$ to $\$ 100,000$ annually by selling only irradiated strawberries.

- Reduce wastes by 10-20\%

- Don't have to cut prices to move aging produce

- Heavy labor costs associated with dumped produce

- Can pick and sell riper, tastier fruit

"One thing we've realized is that the strawberry grower is able to harvest a riper, sweeter strawberry because we know we've got the extended shelf life from irradiation." Jim Corrigan, Owner, Carrot Top Market

- Suburban Chicago housewives prefer irradiated strawberries

"There's no question that when we sell irradiated strawberries, regardless of the price, the volume of sales jumps." Jim Corrigan, Owner, Carrot Top Market 


\section{BARRIERS/RISKS/LIABILITIES}

\section{Cs-137 safety concerns}

- Water solubility/ product history

"The other big argument against food irradiation is that there was an accident at the Georgia plant. At a public meeting, we may simply point out that the accident occurred with cesium, and now we're using cobalt." Jackie Ferreira, Marketing Manager, SteriGenics

- Low opinion with irradiator designers, industry experts, potential customers

"The biggest problem is the present capsules (for cesium) aren't designed for use, they're designed for storage." Dr. Harry Farrar, consultant

"Cesium has no potential" in the food irradiation market. "It has been pretty much ruled out. It's water soluble, so if there's a leak, it will spread. Most people in the industry have discounted it as an isotope source. It's not a factor." Dr. Jerry Wellbourn, Director of Technical Services, Silliker Laboratories 
"I don't see any future for cesium. Even the Chinese don't bother with cesium, they import cobalt. It's a dangerous medium to use in wet pool storage." Dr. George Giddings, Food Irradiation Specialist, Food \& Agriculture Organization, International Atomic Energy Agency

- Financially risky - SteriGenics lost \$ millions

"I don't think anybody in the industry would go near it at any price. The SteriGenics site is covered over with concrete and won't be used for something like the next 200 years. I don't see anybody going near cesium." Paul Moriarty, Director of Sales \& Marketing, RTI, Inc. 
Cs-137 politically and promotionally risky

- Tie-in with nuclear industry viewed as negative

"One of the biggest ammunitions that groups like Food \& Water uses against food irradiation is that irradiation is a diabolical government scheme to use radioactive wastes on foods. We don't have to get into that with cobalt. It's a clean argument against it." Jackie Ferreira, Marketing Manager, SteriGenics

- Lightning rod for opponents

"Technically, I don't see any major problems (with using cesium) if its re-encapsulated properly. But politically, there's a lot of baggage that goes along with it. Politcally, they're not going to win that fight (versus anti-nuke, anti-irradiation activists). Right now, it's a losing battle." Dave Eakin, VP Operations, New Horizon Technologies

"Maybe a few years down the road it'll (market for cesium) open up. But there's a lot of bad baggage there. All cesium does is create a lightning rod for the anti's who try to say the government is trying to feed us nuclear bomb material. It's a whole heckuva lot easier to try to deal with that equation by just dealing with cobalt. Once irradiated foods are accepted in a few years, the source won't matter." Michael Brown, President and CEO, New Horizon Technologies 
- Earlier, fumbled attempts in mid-80s

"DOE had money available for building six demonstration irradiators, which I think were going to be cesium units. They were saying it was one of the beneficial spin-offs of the nuclear weapons industry, which was the totally wrong approach to take." Dr. Lyle Wong, Plant Industry Director, Hawaii Department of Agriculture 


\section{Irradiation opponents}

- Use Cs-137 to discredit all food irradiation

- Organic farmers

- Food \& Water

- tactics: tell the big lie

-. "No high quality studies on the long-term safety of food irradiation have been done." -. clever marketing: "Hiroshima hens", T-shirts -. "The Department of Energy has a solution to the problem of radioactive waste. You are going to eat it."

- 3,500 members

- budget of $\$ 500,000$

- recently targeted by Wall Street Journal

- appear to be running out of steam

- Health Research Group (Ralph Nader)

- Center for Science in Public Interest

- Safe Tables Our Priority (STOP) -- fastfood safety 
- Effect on major supermarket chains and processors

- signed bogus pledge

- mail campaigns

- picketing stores and stores suppliers

-. harassing late night phone calls

"A lot of the opponents have these elaborate conspiracy theories, like they're saying it's (irradiation) being pushed by the government as a way to dispose of nuclear wastes. These rumors are very difficult to squelch." James Berg, Video Producer, Iowa State Extension Service

Public ignorance, perceptions

- No organized promotion of food irradiation

- Survey by Institute of Food Technologists: $30 \%$ of consumers believe irradiated foods are radioactive. 
DOE policies, strategies vary with political climate

- Potential customers wary of committing to long-term deals

- Industry believes DOE and NRC have made final decision to ban Cs-137 for commercial irradiation

"The DOE is trying to recall all the cesium that's out - there and are trying to get out of the business." George Pauli, Director of Division of Product Policy, Food \& Drug Administration.

- Will DOE take back Cs-137 like Nordion does?

- Who will be calling the shots in 2-4 years?

- Will DOE even exist? 
Past difficulties in dealing with Hanford

- J.L. Shepherd

-Isotope Products Labs ("bullheaded")

- Nordion ("forget it")

- Neutron Products ("get them out of the business")

- Yet they have successfully dealt with other DOE sites (Idaho, Oak Ridge)

USDA packaging, labelling rules major obstacle for poultry

- Red meat petition addresses this

Long-term availability of Cs-137

- What happens when all cesium chloride used up?

- Will DOE resume re-processing of nuclear waste? 
Cobalt-60 has strong headstart

- Challenger must knock-out incumbent

"As it stands right now, we would not use cesium. We can encapsulate and shield our cobalt with a high level of security. Our company's safety and quality with cobalt is at such a height, that we wouldn't want to endanger it by using cesium. We can say that for thirty years we've operated without an accident. That's a high moral ground. Reasonable people can accept that. For us to consider using cesium might mean we would lose that position." Jim Cottee, Senior Market Development Specialist, Nordion International

- No compelling reason to switch isotope sources

Cobalt-60 "is the only one working commercially on a basis that would satisfy the meat industry's needs." Dr. James Marsden, (formerly with American Meat Institute), Kansas State

"It will take many, many years before cesium comes close to taking over market share from cobalt. It's at least 50 years away. There's lots of cobalt around, plus companies that invested in using cesium in the past ran into problems." Dr. Harry Farrar, consultant 
- Co-60 becomes non-radioactive much more quickly

"Cesium has never been anybody's first choice. Cobalt has captured an overwhelming market share for practical reasons. It has fairly good penetrating ability." George Pauli, Director of Division of Product Policy, Food \& Drug Administration

- Installed base uses water pools

- New future sources of cobalt-60 expected to come on line

-Will make cobalt-60 even more price competitive

"If more cobalt supply comes on line because of new reactors being built by the Koreans, Argentinians and South Africans, then it would be very tough for cesium to get a piece of the action. Unless it's very cheap and they (Hanford) promise to take it back (once half-life is reached). The Canadians have marketed cobalt that way, and have been successful." Dr. Manuel LagunasSolar, Crocker Nuclear Laboratory, University California at Davis 
Concerns about irradiation affect on food quality, taste

- Scientists convinced it's okay

- Food industry unsure

- Can overcome problem with actual taste tests

- Implication: must have site to satisfy their questions

Industry turning to other food treatment alternatives

- New carcass cleaning methods expected to diminish

E. coli incidence

- Supermarkets now clean grinders and processing equipment at end of each shift

- Controlled atmosphere processing as fumigant replacement

- Impetus on research into cold treatment

- Greater awareness by public, restaurants on cooking requirements example -- Von's Supermarkets distributes safe meat cooking booklets to customers) 
MARKET SIZE AND FORECAST

Overarching Assumptions

1. There will be no major goverment push by Congress, Cabinet, President, or Surgeon General to encourage or mandate usage of food irradiation.

2. There will be no highly visible foodborne illness outbreaks resulting in multiple deaths.

3. There will be no major nuclear operation incidents domestically or internationally (e.g. Chernobyl, Three Mile Island). 
Operating Premises

1. Grav*Star is the only current customer for using Cs-137 from Hanford.

2. Gray*Star's design lends itself best to seasonal fruit/vegetable applications.

3. Food irradiation's primary penetation mechanism will be to replace existing chemical fumigation and heat treament methods that are unsatisfactory (hot-water baths) or outlawed (MB, EtO).

4. Gray*Star's approach is viable for fruit and vegetable, but much less attractive for high throughput applications in meat and poultry.

5. Most attractive sector of the fruit/ vegetable market is for imported produce treated to meet quarantine requirements.

- no obstacle placed by US public opinion and special interest groups.

6. Foreign markets for Cs-137 will develop before the U.S. market does.

- irradiation using Cs-137 will lag Co-60 by 2-3 years

7. Conversion rate of existing treatment sites to irradiation will be approximately $60 \%$. 


\section{J O Y C E \\ \&ASSOCIATES}

Goal of.Hawaiian fruit growers.

"We'd like to see someone build an irradiator in Hawaii. We'd like to be able to treat the fruit locally and ship it to California and other states. I'm absolutely convinced that this thing is going to fly (building a new irradiation plant in Hawaii) and we will be supplying a lot of markets on the mainland with Hawaiian fruits." Dr. Lyle Wong, Plant Industry Director, Hawaii Department of Agriculture 


\section{Installed Base of Fruit and Vegetable}

Quarantine Treatment Facilities

Technology

Hot-water bath plant

Hot-water bath plant

Hot-air plant

Hot-air plant

Ethylene Oxide

Methyl Bromide

Methyl Bromide
Location

Hawaii

Central \& S. America 200

Hawaii

Fiji

U.S.

U.S.

Chile
80

\# Facilities

7

1

1

7

50 


\section{PROJECTED SALES OF FOOD IRRADIATORS}

\begin{tabular}{|c|c|c|c|c|c|c|c|c|c|c|c|}
\hline \multirow[t]{2}{*}{ All irradiators } & \multicolumn{10}{|c|}{ Year } & \multirow[b]{2}{*}{$\begin{array}{l}10 \mathrm{yr} . \\
\text { total }\end{array}$} \\
\hline & 95 & 96 & 97 & 98 & 99 & 00 & 01 & 02 & 03 & 04 & \\
\hline US/Hawaii & 1 & 2 & 2 & 4 & 6 & 8 & 6 & 4 & 3 & 2 & 40 \\
\hline $\begin{array}{l}\text { International } \\
\text { (mainly Latin } \\
\text { America) }\end{array}$ & 5 & 10 & 20 & 25 & 35 & 25 & 20 & 20 & 10 & 10 & 180 \\
\hline Totals & 6 & 12 & 22 & 29 & 41 & 33 & 26 & 24 & 13 & 12 & 220 \\
\hline \multicolumn{12}{|c|}{ Cs-137 irradiators } \\
\hline & 95 & 96 & 97 & 98 & 99 & 00 & 01 & 02 & 03 & 04 & $\begin{array}{l}10 \mathrm{yr} . \\
\text { total }\end{array}$ \\
\hline $\begin{array}{l}\text { Units } \\
\text { (total 31) }\end{array}$ & 0 & 0 & 3 & 4 & 6 & 5 & 5 & 4 & 2 & 2 & 31 \\
\hline
\end{tabular}

10 year demand for Cs-137 - 31 units at $1.2 \mathrm{MCi}$ each

$$
-37 \mathrm{MCi}
$$

$-\$ 37 \mathrm{M}$ at $\$ 1 / \mathrm{Ci}$

\footnotetext{
*includes fruit and vegetable applications only. Low throughput meat and poultry sales would be additional
} 


\section{US Market Growth}

- President of Food Tech Services (former Assistant Secretary for Agriculture) believes entire market size for that . segment would be "30 to 40 irradiators strategically located to serve multiple facilities. Some of them could be built in the plants to handle the high-risk products, like poultry and ground beef." Harry Mussman, President, Food Technology Service

- Based upon size of existing Food Tech Services irradiator, this is how Mussman's prediction might play out in the United States.

1995 -- one new irradiator (Tustin, CA, by SteriGenics)

1996 -- one new irradiator (Isomedix plant comes on line)

1997 -- one new irradiator (Hawaii)

1998 -- some companies begin irradiating ground beef, 5 or 6 new irradiators are built, primarily for ground beef.

1999 -- 10 to 12 new irradiators are built, technology spreads to poultry industry also

2000 -- another 10 or so are built, market begins to saturate 
Target Markets for Fruit \& Vegetable Quarantine Restrictions

- Primary Countries (major quarantine importers to U.S.)

- - Chile -- citrus, stone fruits, soft fruits, berries, some vegetables

- Mexico -- citrus, stone fruits, soft fruits

- Argentina -- berries, stone fruits, grapes

- Peru -- soft fruits, vegetables

- Costa Rica -- soft fruits, tropical fruits

- Guatemala -- berries, onions, beans

- Honduras -- cantaloupe, watermelon

- Panama -- melons

- Brazil -- melons, soft fruits, grapes

- Uruguay -- stone fruits, grapes

- Secondary Countries (minor quarantine importers to U.S.)

- Australia -- orange

- Italy -- chestnut, grapes

- France -- lentil

- Columbia - yam

- Jamaica - yam

- Indonesia - ginger root

- Ecuador -- lime, banana

- Bahamas -- citrus

- Phillipines

-. Venezuela

- Morocco

- Portugal

- Spain 


\section{CONCLUSIONS}

1. U.S. market for food irradiation in infancy

- Signs of it taking root

- Still many barriers/high resistance

- Hamstrung by lack of dynamic drivers

- no big players

- fuel but no engine

- opinion of industry itself

2. If all goes well, food irradiation will be introduced and accepted in U.S. over next five.years.

3. Best penetration route for North American market is institutional food service

- Hospitals and nursing homes

4. Good potential for overseas business, especially Latin America and Asia

- Doesn't carry same baggage vis a vis Cs-137

- No organized opposition, less media scrutiny

- Strong incentive to meet quarantine/regulatory restrictions

5. Cumulative markets for food irradiators by year 2004:

- U.S.

- Latin Am. Total
40 units

180 units

220

6. Cs-137 comes packaged with credibility problems in U.S.

- Co-60 the irradiation source of choice

- Cs-137 must follow Co-60's wake; cannot lead 


\section{$\frac{\text { J OYCE }}{\text { \&ASSOCIATES }}$}

7. Vast majority of industry opinion (politically savvy) favors Co-60

- $80 \%$ say Cs-137 no chance for long time

- $15 \%$ say slight chance for Cs-137 in near future

- 5\% say Cs-137 has good chance in near future

8. Gray*Star's irradiator well-conceived, well-received - In and of itself, not enough to overcome barrier in US of public and industry opinion on Cs-137 safety.

9. Fundamental differences in irradiator design capital cost and operating cost make batch systems more economic for lower throughputs; on-line continuous and freestanding better value for high throughputs.

10. Gray*Star design best suited for fruit and vegetable - Co-60 likely to dominate in higher throughput meat and poultry applications and where Cs-137 offers anything less than a substantial economic advantage.

11. Hanford can cause the market for Gray*Star's batch unit to expand by selling Cs-137 on a cost recovery basis:

- at $\$ .50$ per $\mathrm{Ci}$, for example, rather than the market's perceived level of $\$ 1$ per $C i$

12. Disposal of $\mathrm{Cs}-137$ will be an issue

- Gray*Star strategy for re-selling of product at half-life assumes original market for meat and poultry

13. Economics of irradiator operation suggest/mandate a price for Cs-137 of $\$ 1 / \mathrm{Ci}$ or less.

- vs. top price of $\$ 1.80 / \mathrm{Ci}$ for Co-60

- In view of increased supply of Co-60 (Argentina, Korea, South Africa), which will drive down price. 


\section{$\frac{\text { JOY C E }}{\text { Z OSSOCIATES }}$}

14. Competing technologies (machine sources) do not present a sizable threat.

- Biggest threat is Cs-137's own safety record and negative public opinion re: irradiation as a technology.

- Other potential threat is outspoken stance by industry itself (Nordion, SteriGenics, et al) against Cs-137

15. Expected market share for Cs-137 over 10 year periods ending 2004:

- $14 \%$

- 31 irradiators

- $37 \mathrm{MCi}$

16. Market unlikely to accept Cs-137 from Hanford in its present format.

- Water-soluble

- French working on non-soluble gel format

- Safety of encapsulation key issue

17. Hanford perceived as difficult to deal with.

- Perceived as less sensitive to needs of private sector than - Idaho, Oak Ridge, Savannah River.

- Some work needs to be done to improve performance, overcome market perceptions.

- Industry more pre-disposed to working with private encapsulation.

18. Best bet for partner to take over Hanford role:

- Babcock \& Wilcox - encapsulation only

- Isotope Product Labs - small company

- Nordion/ Neutron Products -- no current interest 
$\frac{\text { J O Y C E }}{\text { \&ASSOCIATES }}$

19. Other potential partners for Hanford can facilitate the penetration of Cs-137 into favorable markets.

- Western Industries

- J.L. Shepherd

- Babcock \& Wilcox

- Incremental resource commitment

- Go ahead if favorable

- Pull back if not

- Gray*Star

- Isotope Product Labs

- Too small to move N. American market by themselves 
$\frac{\text { JOYCE }}{\underline{\text { \& ASSOCIATES }}}$

\section{RECOMMENDATIONS}

1. Pursue strategic relationship with partners that can:

- design the capsule

- encapsulate the source

- build the cask

- Best visible choices:

- Babcock \& Wilcox

- Isotope Product Labs

- Gray*Star (for capsule design)

- Possibly in four-way combination

2. Evaluate feasibility of providing Cs-137 in non-soluble/lesssoluble form

- e.g., cesium nitrate/cesium gel

- to enhance its attractiveness with irradiator design/build firms

- monitor technology developments elsewhere, e.g. France/UK./ Russia

- consider a technology license with any developer of advanced/less soluble form of cesium

- test viability of any advanced form of cesium with irradiator firms (for attractiveness) before investing heavily 
3. Evaluate economics of supplying encapsulated cesium at $\$ 1 / \mathrm{Ci}$

- in light of projected storage costs

4. Open dialogue with other hesitant, but open-minded irradiator designers:

- Shepherd

- Food Tech

- Applied Food Processors (parent is applied Radiant Energy)

5. Introduce them to plan centering on:

- privatization of encapsulation process

- lowered price for Cs-137

- improved capsule design

- best identified market opportunities

Goal: assure that more than one irradiator designer offers product using cesium 
$\frac{\text { JOYCE }}{\text { \&ASSOCIATES }}$

\section{RESPONDENTS}

Contract Irradiation Service Companies

Ed Miller

SteriGenics International

Fremont, CA

510-770-9000

John Deeds

Isomedix, Inc.

Whippany, NJ

201-887-4700

Jim Myron

Applied Radiant Energy Corp.

Forest, VA

804-385-5300

Harry Mussman

President

Food Technology Service

703-820-8454

Ken Kosiel

General Manager

Irradiation Industries

Gaithersburg, MD

301-840-0900 
Jackie Ferreira

Marketing Communications Manager

SteriGenics

Fremont, CA

510-770-9000 ext. 121

Fred Harris

Safety Director

Food Technology Services

Mulberry, FL

813-425-0039

Harley Everett

Executive Vice President

Food Tech Services

Mulberry, FL

813-742-3364

Paul Moriarty

Director of Sales \& Marketing

RTI, Inc.

Rockaway, NJ

201-625-8400

\section{Irradiation System Designers}

Michael Brown, President and CEO

Dave Eakin, VP Operations

New Horizon Technologies

Richland, WA

509-372-4868 
Russell Stein

Vice President

Gray*Star

Mount Arlington, NJ

201-398-3331

John Griessmayer

Executive VP

Applied Food Processors

Forest, VA

804-525-8582

Michelle Marcotte

Market Development Specialist

Food Irradiation Applications

Nordion International, Inc.

Kanata, Ontario

613-592-2790

Dr. Martin Welt

Chairman/CEO

Alpha Omega Technology, Inc.

Parsippany, NJ

201-292-3600

Jim Cottee

Senior Market Development Specialist

Nordion International

Kanata, Ontario

613-592-2790 


\section{$\frac{\text { JOYCE }}{\text { \&ASSOCIATES }}$}

Joe Shepherd, Jr.

Director of Business Development

J.L. Shepherd

San Fernando, CA

818-898-2361

\section{Isotope Suppliers}

Marvin Turkenish

Neutron Products, Inc.

Dickerson, MD

301-349-5001

Geraldine Barrett

Quality Assurance Manager

Neutron'Products

Dickerson, MD

301-349-5001

Dr. Gary Strathum

Isotope Product Laboratories

Burbank, CA

818-843-7000

Dr. Ian Travena

Vice President

Nordion International

Kanata, Ontario Canada

613-592-2790 
$\frac{\mathrm{J} Y \mathrm{Y} C \mathrm{E}}{\text { \&ASSOCIATES }}$

Competitive Technologies

Terry Heyliger

Thermal Processing Manager

FMC Corp.

Madera, CA

209-661-3200

Richard Mendoza

Product Manager

Medical Processing Machines

Titan-Beta Corp.

Dublin, CA

510-828-0555

Richard Plant

President

Electron Technologies Corp.

South Windsor, CT

203-289-7451

Ronald Kaye

Sr. Member of Technical Staff

Sandia National Labs

Albuquerque, NM

505-845-7658

Dennis Olson

Director

Iowa State University Utilization Center for Agricultural Products

Ames, IA

515-294-1055 
David Park

Manager of Technical Consulting Process

Food Processing Systems Division

FMC Corp.

Madera, CA

209-661-3200

James Hackett

Accelerator Product Manager

Radiation Dynamics

Edgewood, NY

516-254-6800

Don Lander

VP Sales \& Marketing

Pure Pulse Technologies

San Diego, CA

619-514-1253

Barbara Hunter

Fumigation Division Marketing Director

Western Industries

Whippany, NJ

201-515-0100

Meat Industry

Dr. James Marsden

(formerly with American Meat Institute)

Kansas State

Manhattan, KS

913-532-6131 
J O Y C E

\&ASSOCIATES

Janet Williams

Dir. Scientific \& Technical Affairs

American Meat Institute

Arlington, VA

703-841-2400

Kirk Jones

Director of Product Integrity and Food Safety

Beef Division

Monfort, Inc.

Greeley, CO

303-353-2311, ext. 8045

Robert Seward

Director of Food Technology

McDonald's

Hinsdale, IL

708-575-6378

David Meeker

VP Research \& Education

National Pork Producers Council

Des Moines, IA

515-223-2600 
$\frac{\text { JOYCE }}{\text { \&ASSOCIATES }}$

Stuart Polevoy

Chairman

Signature Foods

Omaha, NE

800-228-0115

Poultry Industry

Dr. Joseph Pocius

Director of Scientific and Regulatory Affairs

National Turkey Federation

Reston, VA

703-435-7206

Dr. Kenneth May

(Retired)

National Broiler Council

North Wilkesboro, NC

910-667-2913

Charles Ellis

President

Ellis Poultry Processing, Inc.

Delano, CA

805-725-7671 
Stephen Pretanik

Director of Science and Technology

National Broiler Council

Washington, DC

202-296-2622

Institutional Food Service

Jo Ellen Coleman

Director of Food Service

Flagler Hospital

St. Augustine, FL

904-825-4415

Harold Holler

Governance Team

American Dietetic Assn.

Chicago, IL

312-899-0040, ext. 4896

Various Food Industries

Bob Harrington

Assistant Director of Technical Services

National Restaurant Assn

Washington, DC

202-331-5900 
Ed Elkins

Chief Scientist, Chemistry Division

National Food Processors Association

Washington, DC

202-639-5975

Keith Edo

Vice President

National Food Processors Association Lab

Dublin, CA

510-828-2070

Kathy Means

VP of Membership and Public Affairs

Produce Marketing Association

Newark, DE

302-738-7100

Jim O'Hara

Director of Quality Assurance

Industrial Flavors Division

McCormick's

Hunt Valley, MD

410-771-7710

Roy Martin

VP Science \& Technology

National Fisheries Institute

703-524-8880 
$\frac{J O Y C E}{\& A S S O C I A T E S}$

Supermarket/Retail Industry

Jeanette Murphy

Quality Food Centers

Bellevue, WA

Goldie Caughlan

Puget Consumers Co-op

Seattle, WA

206-547-1222

Jim Corrigan

Owner

Carrot Top Market

Glenview, IL

708-729-1450

- John Geisler

Supervisor, co-owner

Wyndle's Foodland

Plant City, FL

813-754-2785

Walt Churchill

Owner

Churchill Supermarkets

Toledo, $\mathrm{OH}$

419-872-6901 


\section{$\frac{\text { J O Y C E }}{\text { QASSOCIATES }}$}

Gayle Prince

Director of Regulatory Compliance

Kroger Stores

Cincinnati, $\mathrm{OH}$

513-762-4209

John Farquar .

VP Science and Technology

Food Marketing Institute

Washington, DC

202-452-8444

Steve Bennett

Editor

Progressive Grocer.magazine

Stamford, CT

203-325-3500

Dr. Ata Baroudi

VP Quality Assurance

Von's Supermarkets

Arcadia, CA

818-821-5607 
$\frac{\text { J O Y C E }}{\text { \&ASSOCIATES }}$

Food Brokers

Bill Skaife

Owner

Skaife's Garden Club

Carlsbad, CA

619-438-2904

Bill Hargraves

Mgr. Agricultural Products Business Development

Nation's Pride

Plant City, FL

813-425-5966

\section{Consultants}

Dr. Harry Farrar

Consultant

Bell Canyon, CA

818-340-1227

James Fagan

Executive Director

Research \& Development Associates

San Antonio, TX

210-493-8024 
Dr. Jerry Wellbourn

Director of Technical Services

Silliker Laboratories

Homewood, IL

708-957-7878

Don Derr

Consultant

Glen Burnie, MD

410-766-9186

Michael Goldblatt

Consultant

Hinsdale, IL

708-575-3007.

\section{Academia, Food Scientists}

Dr. Edward Josephson

Professor Food Science \& Nutrition

University of Rhode Island

Kingston, RI

401-792-2978

Olivia Wood

Food Science Professor

Purdue University

Lafayette, IN

317-494-8238 


\section{J O Y C E \\ \&ASSOCIATES}

Dr. Christine Bruhn

Food. Marketing Specialist

UCal Davis

Davis, CA

916-752-2774

Dr. Jack Francis

Food Scientist

University Massachusetts

Amherst, MA

413-549-0421

Dr. Dean Cliver

Food Science Professor

University of Wisconsin

Madison, WI

608-263-6937

Dr. Manuel Lagunas-Solar

Crocker Nuclear Laboratory

University California at Davis

Davis, CA

916-752-7439

State and Federal Government Officials

Dr. Donald Thayer

Research Leader

Eastern Regional Research Center

US Dept Agriculture

Philadelphia, PA

215-233-6583 
Rosanna Mentzer Morrison

Agricultural Economist.

USDA

Washington, DC

202-219-0858

Larry Nakahana

Mgr. of Plant Quarantine Branch

Hawaii Dept. of Agriculture

Honolulu, HI

808-586-0846

Dr. Lyle Wong

Plant Industry Director

Hawaii Department of Agriculture

Honolulu, HI

808-973-9535

Dr. Rob Tauxe

Chief of Foodborne \& Diarrheal Diseases Branch

Center for Disease Control and Prevention

US Public Health Service

Atlanta, GA

404-639-3818

Dr. George Giddings

Food Irradiation Specialist

Food \& Agriculture Organization

International Atomic Energy Agency

Vienna, Austria

(43) $12360-1638$ 
Tanya Roberts

Agricultural Economist

Economic Research Service

US Department of Agriculture

Washington, DC

202-219-0857

Dr. Morris Potter

Asst. Director for Foodborne Diseases

Center for Disease Control

Atlanta, GA

404-639-2237

George Pauli

Director of Division of Product Policy

Food \& Drug Administration

Washington, DC

202-418-3090

Joseph Ferrar

Director of Food Safety and Inspection

New York Dept. of Agriculture and Markets

Albany, NY

$518-457-4492$

Jerry Prentice

Supervisor of Consumer Foods

Maine Dept. of Agriculture

Augusta, ME

207-287-3841 


\section{$\frac{\text { JOYCE }}{\text { \&ASSOCIATES }}$}

Jimmy Hopper

Director of Quality and Standards

Tennessee Dept. of Agriculture 615-360-0117

Tom Womack

Exec. Assistant for Public Affairs

Tennessee Dept. of Agriculture 615-360-0117

Dan Inglejohn

Branch Chief

Processed Product Inspection

USDA

Washington, DC

202-501-7319

Ray Beaulieu

Asst. Director for Codes \& Practice Retail Food Protection Branch

Food \& Drug Administration

Washington, DC

202-205-8140

Scott Wood

Agriculture Quarantine Branch Chief Plant Protection \& Quarantine

USDA

Oxford, NC

919-693-5151 
Ms. Pat Santiago

Section Leader

Commercial Use

Nuclear Regulatory Commission

Bethesda, MD

301-415-7269

Lynvel Johnson

Food Technologist Staff Officer

USDA

Washington, DC

Mr. Darcy Axe

Assistant Director for Pre-Clearance

International Services

USDA

Riverdale, MD

301-734-8892

Ken Vick

National Program Leader

Post-Harvest Entomology

Agricultural Research Service

USDA

Maryland

301-504-5321

James Berg

Video Producer

Iowa State Extension Service

US Dept. Agriculture

Ames, IA

515-294-9915 
Miscellaneous

Jennifer Ferrara

Program Associate

Food \& Water, Inc.

Marshfield, VT

802-426-3700

Joe Twohig

Vice President of Investments

Dain Bosworth

Milwaukee, WI

800-933-3246

Larry Katzenstein

Senior Editor

American Health

New York, NY

212-366-8913

Ray Posey

Manager of Business Development

Nuclear Equipment Division

Babcock \& Wilcox

Barberton, $\mathrm{OH}$

216-860-2127 
$\frac{\text { JOYCE }}{\text { \& ASSOCIATES }}$

Larry Redhage

X-R-I Testing

Troy, MI

810-362-2242

Dan Davis

Victoreen, Inc.

Cleveland, $\mathrm{OH}$

216-248-9300 


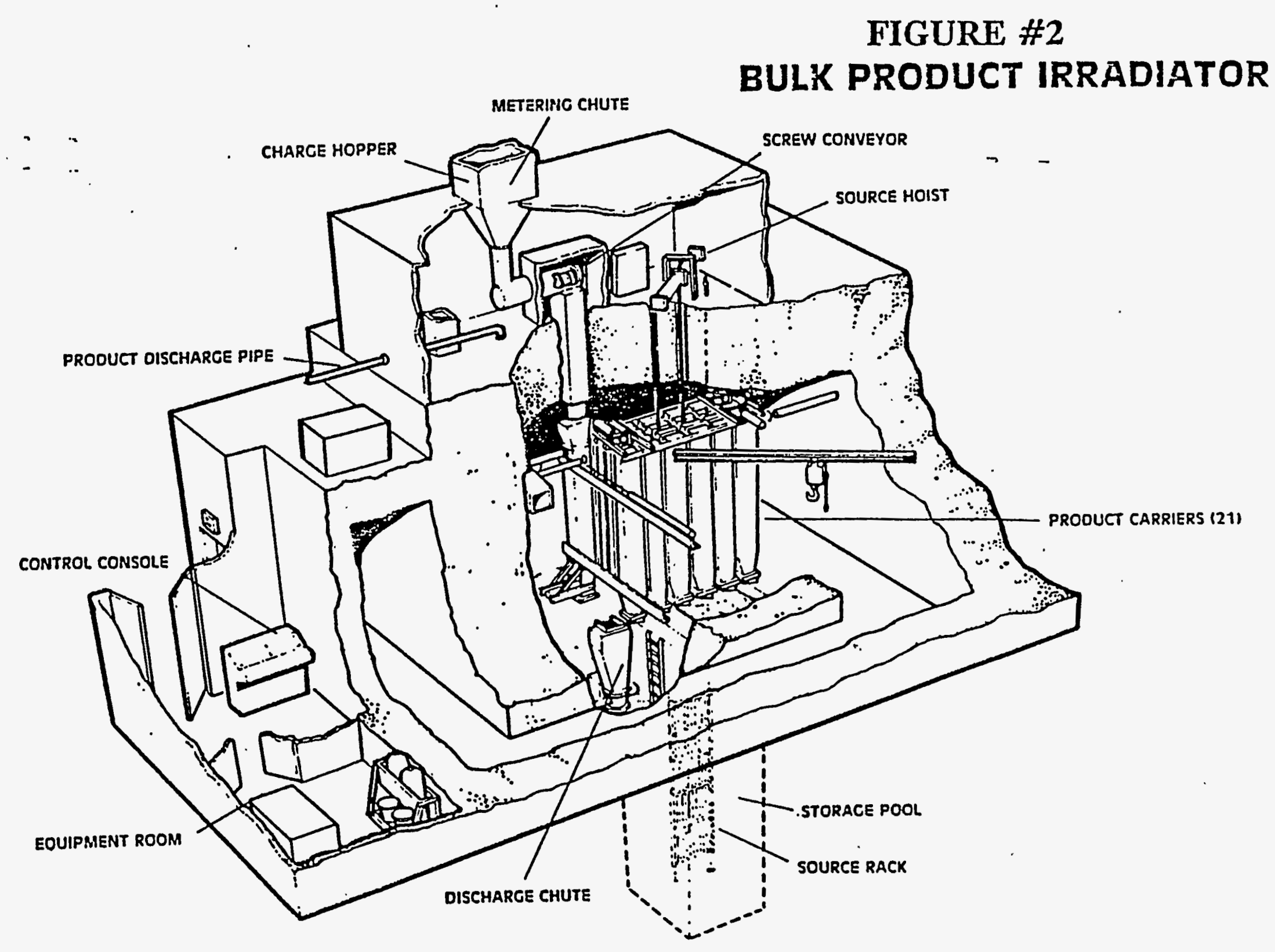


FIGURE \#1

PALLET IRRADIATOR-AUTOKATIC

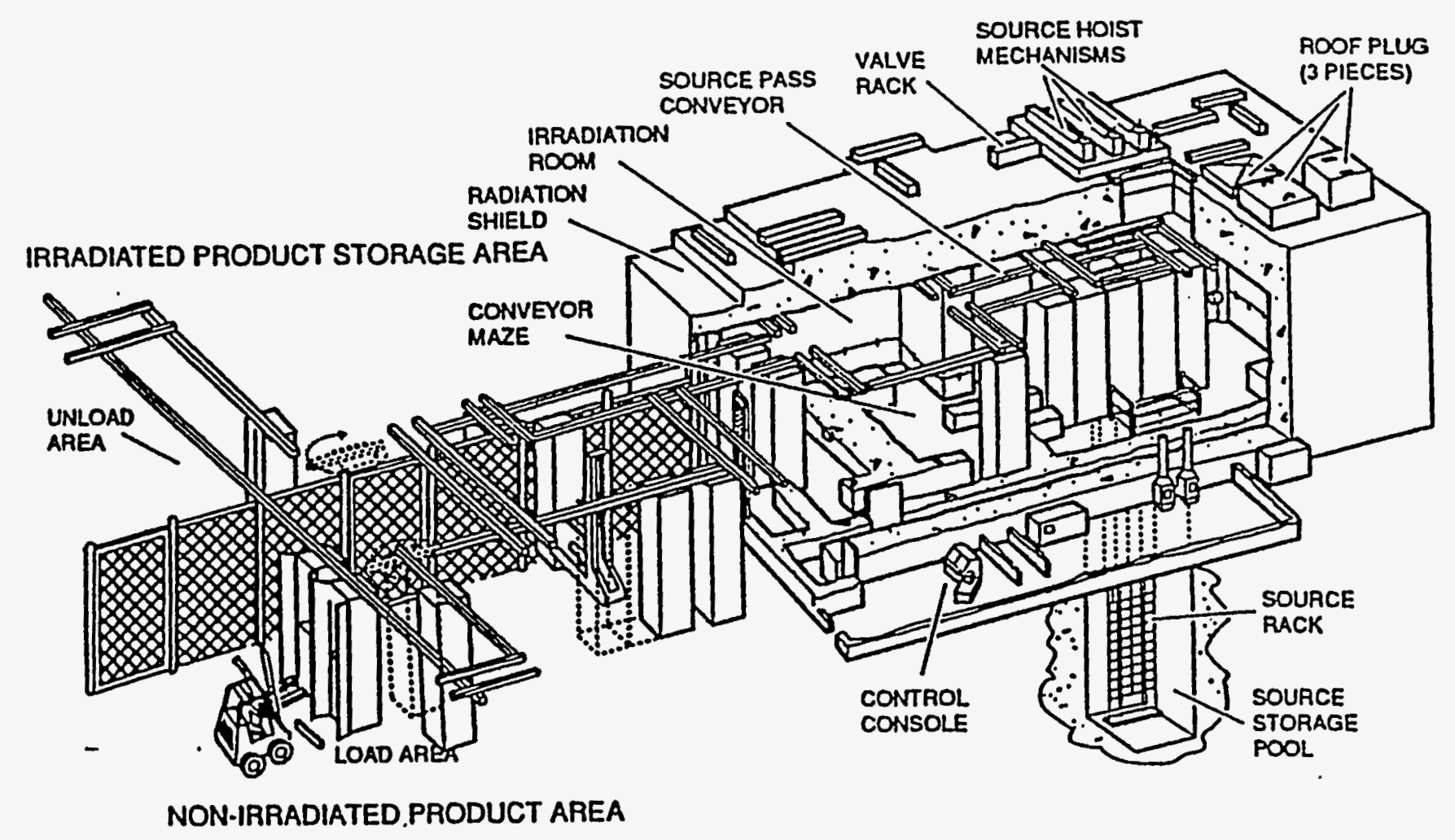




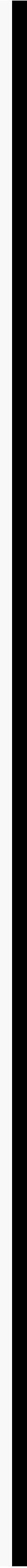


APPENDIX E

VIDEO - THE GRAY*STAR SOLUTION 
